NBER WORKING PAPER SERIES

\title{
DOES OFFSHORING PRODUCTION REDUCE INNOVATION: FIRM-LEVEL EVIDENCE FROM TAIWAN
}

\author{
Lee G. Branstetter \\ Jong-Rong Chen \\ Britta Glennon \\ Nikolas Zolas \\ Working Paper 29117 \\ http://www.nber.org/papers/w29117 \\ NATIONAL BUREAU OF ECONOMIC RESEARCH \\ 1050 Massachusetts Avenue \\ Cambridge, MA 02138 \\ August 2021
}

We gratefully acknowledge useful comments and feedback from Tain-Jy Chen, Erica Fuchs, Guangwei Li, Brian Kovak, Richard Freeman, John Van Reenen, Yanbo Wang, Steve Yeaple, participants of the 2017 NBER Innovation Summer Institute, seminar attendees at Washington University and London Business School, and financial support from the National Science Foundation (SciSIP grants 1360165 and 1360170) and the CMU-Portugal Program. We also thank Chih-Hai Yang of National Central University for his help in obtaining the customs data used in our earlier paper, Branstetter et al. (2015), upon which this current paper builds. Britta Glennon thanks National Central University of Taiwan for its hospitality and intellectual support during her two-month stay there. All errors and omissions remain our own responsibility. The views expressed in this paper are those of the authors and do not necessarily reflect those of the U.S. Census Bureau or of the National Bureau of Economic Research. The views expressed herein are those of the authors and do not necessarily reflect the views of the National Bureau of Economic Research.

NBER working papers are circulated for discussion and comment purposes. They have not been peer-reviewed or been subject to the review by the NBER Board of Directors that accompanies official NBER publications.

(C) 2021 by Lee G. Branstetter, Jong-Rong Chen, Britta Glennon, and Nikolas Zolas. All rights reserved. Short sections of text, not to exceed two paragraphs, may be quoted without explicit permission provided that full credit, including $\odot$ notice, is given to the source. 
Does Offshoring Production Reduce Innovation: Firm-Level Evidence from Taiwan

Lee G. Branstetter, Jong-Rong Chen, Britta Glennon, and Nikolas Zolas

NBER Working Paper No. 29117

August 2021

JEL No. F2,F6,O3,O4

\begin{abstract}
$\underline{\text { ABSTRACT }}$
Does the offshoring of production degrade or enhance the innovative capabilities of manufacturing firms? We contribute to this debate by exploiting a policy shock that differentially affected the ability of Taiwanese firms to offshore some products to China. We find causal evidence that offshoring impacts both the level and nature of innovation. In the technologies directly related to product categories that could be offshored more easily after the policy shock, overall innovation levels decline and innovative effort shifts away from product innovation and towards process innovation. However, we also find evidence of a second-order positive effect of offshoring on the levels of innovation-particularly product innovation-in other parts of the firm's portfolio. These results are consistent with the notion that offshoring production induces a complex reallocation of innovation effort within the firm, both across and within technology categories. Our paper examines this reallocation in the context of Taiwanese electronics firms, and introduces new methods that could be used to study post-offshoring reallocations of innovative effort in other contexts.

Lee G. Branstetter

Heinz College

School of Public Policy and Management

Department of Social and Decision Sciences

Carnegie Mellon University

Pittsburgh, PA 15213

and the Peterson Institute for

International Economics

and also NBER

branstet@andrew.cmu.edu

Jong-Rong Chen

National Central University

Academia Sinica

National Taiwan University

Taiwan

jrchen814@gmail.com

Britta Glennon

The Wharton School

University of Pennsylvania

3620 Locust Walk

Philadelphia, PA 19104

and NBER

bglennon@wharton.upenn.edu

Nikolas Zolas

Center for Economic Studies

U.S. Census Bureau

4600 Silver Hill Road

Washington, DC 20233

nikolas.j.zolas@census.gov
\end{abstract}




\section{Introduction}

Over the past several decades, there has been a dramatic shift in the global distribution of manufacturing. Driven by opportunities for cost reductions, many multinational firms have offshored much of their production to lower-wage countries while continuing to undertake skill-intensive activities such as marketing, strategy, and R\&D in the home country. Experts have disputed the impact of this shift in production on firms' innovative capacity for decades. On the one hand, influential general equilibrium models of this phenomenon suggest that a relocation of manufacturing can raise the global rate of innovation and consumer welfare in both the source and host countries (Branstetter and Saggi 2009; Helpman 1993; Lai 1998). However, other strands of the literature argue that separating the manufacturing and R\&D functions within a firm can undermine the firm's innovative capacity by reducing the potential for "learning-by-doing," thereby creating challenges for knowledge transfer and feedback between R\&D and production, and changing the incentives for investing in cutting-edge research (Cohen and Zysman 1987; Fort et al. 2020; Fuchs 2014; Pisano and Shih 2009). Despite longstanding interest in resolving this theoretical ambiguity through empirical evidence, the endogeneity of offshoring and innovation - at the firm, industry, and country level - has made it difficult for researchers to come to definitive conclusions. Recent studies (Autor et al. 2016; Bloom, Draca, and Van Reenen 2016; Campbell and Mau, forthcoming) have examined the impact of plausibly exogenous import shocks on innovation. However, the prior literature has struggled to estimate the sign or magnitude of the causal effect of offshoring on innovation in a credible way. ${ }^{1}$

We advance our understanding of the impact of offshoring on innovation by going beyond previous empirical studies in four respects. First, we identify a causal relationship between offshoring and innovation using a 2SLS estimation strategy that exploits a well-documented but under-researched policy shock in Taiwan. This policy shock differentially affected the cost of offshoring production to China for different product categories in Taiwan's electronics sector and spurred an immediate surge in offshoring to China. Second, most of our sample firms have a product portfolio that spans multiple product categories. We exploit a unique data source that allows us to observe the offshoring of particular products and components within firms, allowing us to identify intra-firm adjustments to offshoring and innovation in the aftermath of our policy shock. This allows for a far more granular analysis of the impact of our offshoring shock than would be possible if we were limited to firm-level data (as is typical in this literature). Third, we use keyword generators and text mining algorithms to connect the patents generated by our sample firms before and after the policy shock to the products and components in their production portfolio. This allows us to identify the impact of the offshoring of particular products, components, and stages of production on patenting in the areas of technology most likely to be connected to the offshored activity. In doing so, we also demonstrate the feasibility of a set of techniques that could be more broadly applied to identify the effect of trade and FDI shocks on the innovative activities of multiproduct firms. Finally, we can distinguish between product and process innovations, which allows us to observe the effect of the policy shock on the nature of innovation as well as the level of innovation, as measured by patents.

Once we are able to examine the impact of an exogenous offshoring shock on different parts of the firms' patent portfolios, an interesting and complex picture emerges. First, we find that offshoring has an enduring negative effect on the quantity of firm patents located within the technological domains that are related to the products it offshored. We characterize this as a "first-order" negative within-category effect

\footnotetext{
${ }^{1}$ Bernard et al. (2020) examine the relationship between offshoring and reorganization/innovation within Danish firms, but, unlike us, they are unable to measure production outside of Denmark. Bøler, Moxnes, and Ulltveit-Moe (2015) examine the relationship between offshored inputs and $R \& D$ using Norwegian data, but document a causal relationship running in the opposite direction to the one we explore here.
} 
on the level of innovation. These empirical results prove impressively robust to a wide range of robustness tests and alternative specifications.

In addition to the negative effect on the level of within-category innovation, the exogenous offshoring shock also affected the nature of within-category innovation, in that offshoring shifted the direction of innovation in the affected product categories towards process innovations. This measured change in the nature of innovation is consistent with the hypothesis of Fuchs and coauthors (Fuchs 2014; Fuchs and Kirchain 2010; Yang, Nugent, and Fuchs 2016), who argue that the differing characteristics of production sites located in different nations can alter the type of innovations most profitable for firms to pursue. When allowed to offshore production to a location with much lower factor costs, Taiwanese firms found that the new offshoring possibilities shifted the trade-off they faced between competing on new product technologies (achieved through product innovation) versus competing on price. The latter option became less costly, thanks to the reduced factor costs of the new production site. However, taking full advantage of reduced costs associated with the new production site required adjustments to the production process, inducing a shift away from product innovation and towards process innovation in the domains that could now be offshored.

This interpretation is strengthened when we examine post-offshoring shock patenting trends within product categories that were characterized by relatively more process or product innovation at the onset of the offshoring shock. Our negative within-category effect is driven almost entirely by product categories with a high fraction of product innovation before the shock. Our results are consistent with the notion that offshoring production to a cheaper location changes the optimal R\&D investment strategy of the firm in the technological domains associated with the products it offshores.

We also provide evidence on the existence of a second-order positive effect on innovation in product categories that were not directly affected by the policy shock but are technologically proximate to the product categories that were. This is a cross-category effect, and is present not only in a positive change to the level of innovation but also in a change in its nature. In these categories, the mix of innovative activity shifts towards product innovation. These findings are consistent both with economic theories (Bloom et al., 2019) and with the case study of McKendrick, Doner, and Haggard (2000), which suggest that the resource savings generated by offshoring can be invested in the development of new product varieties.

Our results thus demonstrate that offshoring induces a complex (but economically rational) reallocation of innovative effort across and within technology categories. A narrow focus on within-category, level effects misses much of this reallocation, and therefore leads to an incomplete assessment of the impact of offshoring on innovation. The methods introduced in this paper could be used by other researchers to take a more wholistic approach to evaluation of the full impact of offshoring on innovation in other contexts.

\section{Does the Relocation of Manufacturing Undermine Innovation? A Literature Review}

One strand of research underlying the argument that offshoring manufacturing can fundamentally impede a firm's capacity to innovate is rooted in the synergistic relationship between the manufacturing and R\&D functions of the firm and the dangers of separating these functions (Cohen and Zysman 1987; Fort et al. 2020; Ketokivi and Ali-Yrkkö 2009; Kline and Rosenberg 1986; Pisano and Shih 2009; Teece 1996). ${ }^{2}$

\footnotetext{
${ }^{2}$ When manufacturing is offshored to advanced industrial countries rather than low-wage developing countries, a separate strand of the literature argues that this kind of relocation of manufacturing can augment innovation by providing firms with access to local knowledge, resulting in reverse technology transfer and increased depth of knowledge for the firm (Dunning 1998; Florida
} 
This view can be traced back to Schumpeter (1939), who defined innovation as the process of developing an idea from concept into marketable products and services, a process that requires continuous collaboration, mutual adaptation, and the transfer of learning between those who design and those who manufacture. Direct interaction between production and R\&D personnel could be crucial for the success of researching and developing some complex products and processes. ${ }^{3}$ A geographic separation of these groups could therefore undermine innovation capabilities. However, the degree of positive feedback between manufacturing and $\mathrm{R} \& \mathrm{D}$ is likely to depend on the nature of the $\mathrm{R} \& \mathrm{D}$ being undertaken. ${ }^{4}$ The part of the firm's R\&D portfolio most closely tied to the technology embodied in the products and processes that are offshored may decline while other components of the same firm's R\&D portfolio may be relatively unaffected. Our results appear at first glance to be consistent with this storyline; we find empirical support for the existence of a robust negative effect of offshoring on innovation levels in the offshored product categories.

However, when we look more closely at the changes to the nature of innovation, we discover a more complicated story that does not align as neatly with the story that the separation of production and R\&D negatively impacts innovation. In particular, the work of Pisano and Shih (2009) suggests that it is in the domain of process innovation that one would expect the link between R\&D and manufacturing to be the strongest. This view receives at least some indirect support from the work of Fort et al. (2020), who find that the decline of U.S. manufacturing coincides with a decline in manufacturing patents and a move towards more service-oriented patents. According to this story, a decline in innovative capacity due to the separation of production and R\&D would be observed with an overall decline in patents, and a disproportionate decline in process patents. While, as noted above, we do find a negative effect on patent levels, we find a shift away from product patents and towards process patents in the newly offshored categories, which is inconsistent with this view.

A separate strand of research helps explain our finding of a shift towards process innovation after offshoring. This literature has identified a different mechanism by which moving manufacturing abroad especially to a developing country - could change the incentives offshoring firms face when investing in R\&D most closely associated with the offshored product (Fuchs 2014; Yang, Nugent, and Fuchs 2016; Fuchs and Kirchain 2010a). As noted in our introduction, when firms are able to offshore production to a location with much lower factor costs, this shifts the trade-off they face between competing on quality and performance (achieved through product innovation) versus competing on price. The latter option becomes less costly, thanks to the lower factor costs of the new production site, inducing a shift away from product innovation. However, offshoring firms will often have to invest in additional process innovation, reengineering their processes to take full advantage of the lower factor costs. This generates a shift in innovative effort towards process innovation. This logic is illustrated in Figure 1, which depicts a case in which offshoring drives both an overall decline in the overall level of innovation and a shift toward process innovation. We find strong empirical evidence for exactly this kind of shift after the offshoring policy shock.

Economists have long tended to take a more positive view of the separation of manufacturing and R\&D, arguing that offshoring could have a positive effect on home country innovation. However, the economists' theoretical arguments include long-run, general equilibrium effects, which rely explicitly on

\footnotetext{
1996; Oviatt and McDougall 1994). Economic studies of this phenomenon include Branstetter (2006) and Griffith, Harrison, and Van Reenen (2006).

${ }^{3}$ Japanese industrial and export success in the 1980s was attributed, in part, to the close linkages between design and manufacturing, overlapping product development cycles, and the practice of rotating R\&D personnel through marketing and manufacturing operations (Clark et al. 1987).

${ }^{4}$ The level of positive feedback also surely depends on the good being manufactured, but the literature has not yet identified a way of ranking products or industries in order of the degree to which R\&D can be separated geographically from manufacturing without loss of effectiveness.
} 
a reallocation of resources across products, firms, and even industries. ${ }^{5}$ Drawing upon the concept of an international product cycle originally proposed by Vernon (1966) and the influential theoretical frameworks introduced by Grossman and Helpman (1991a, 1991b) and Helpman (1993), an extensive literature has explored how the shifting of production within multinationals from an industrialized "North" to a lower-cost "South" impacts the rate of innovation within Northern firms (Branstetter and Saggi 2009; Glass and Saggi 2001; Lai 1998). Under a wide range of modeling approaches and parametric assumptions, the shift of production from North to South raises the rate of innovation in the North by freeing up Northern resources formerly used in the production of technologically mature products. After offshoring, these resources can now be reallocated to the development of new products. The disk drive industry case study by McKendrick et al. (2000) asserts that U.S.-based disk drive companies were able to offshore production to Asia and invest the resource savings towards the creation of new, better products that kept them ahead of their (mostly Japanese) competition. To the extent that these effects emerge within multiproduct firms, any increase in overall innovative effort may be likely to show up in product categories other than the ones being offshored. We will refer to this as a second-order, cross-category effect of offshoring on innovation. ${ }^{6}$ Given this logic, we expect that the cross-category effect of offshoring on innovation to be positive, and that it will be biased toward product innovation rather than process innovation. We also anticipate that our estimates of the cross-category effects may underestimate the full effect of this reallocation because our empirical approach only allows us to identify the component of the cross-category effect that shows up within the offshoring firms. To the extent that part of the induced reallocation in R\&D effort arises in firms or industries outside the set of those directly impacted by our offshoring shock, we will not directly observe this in our empirical results. Nevertheless, we find robust statistical evidence in support of these cross-category effects.

Our paper focuses on the deliberate shift of production by multinationals to their offshore subsidiaries, and the impact of this production shift on the R\&D outcomes of the offshoring firms. However, there is a close relationship between our work and the recent papers by Bloom, Draca, and Van Reenen (2016) and Autor et al. (2020). These papers exploit the exogeneity of rapidly rising imports from China to measure the impact of intensifying import competition on European and American manufacturers, respectively, while taking into account the fact that many of their firms have product portfolios spanning multiple categories and even industries, and that the intensity of import competition (and innovative effort) varies across sectors. Bloom, Draca, and Van Reenen (2016) find a positive effect of Chinese imports on multiple measures of innovation, although subsequent work has called into question the positive effect on patenting (Campbell \& Mau, Forthcoming). Autor et al. (2020) find a negative effect of Chinese import competition on patenting. Both papers focus on the first-order, "within-category" effect of import competition on patenting. Neither explores the possibility of second-order, cross-category effects, which are an important component of our findings.

Despite some methodological similarities, these papers have different objectives from ours - they seek to measure the impact on innovation from rising import competition rather than the relocation of manufacturing within the firm across national borders. These two effects are conceptually related, but distinct. European and American manufacturers, as a group, ran a large and growing trade deficit with China in the 2000s. On the other hand, China's growth had a very different impact on Taiwanese firms' trade flows. Taiwanese manufacturers ran a large trade surplus with China in the 2000s that continued to grow rapidly even as a growing volume of components and products were offshored to Chinese affiliates.

\footnotetext{
${ }_{6}^{5}$ An interesting general treatment, with this feature, is provided by Grossman and Rossi-Hansberg (2008).

${ }^{6}$ Klepper (1996) and Cohen and Klepper (1996) draw upon U.S. industrial history to argue that the pace of technological progress slowed in a number of key industries as leading firms shifted from a focus on product-oriented R\&D (that was driving rapid experimentation in basic product attributes and functions) to a focus on process-oriented, cost-reducing R\&D (designed to win market share for successful products by driving down price). Resource constraints within firms meant that rise in processoriented R\&D necessarily reduced investment in product-oriented R\&D. In a sense, offshoring provides a way to reverse this shift.
} 
For most American and European multinationals, FDI in China remains a surprisingly small component of their global corporate operations. For Taiwanese firms, China has become the overwhelmingly dominant FDI host country. Our focus on policy-induced shocks in the cost of offshoring thus makes sense for our target firms.

\section{Taiwan's Policy Change: From “No Haste, Be Patient” (戒急用忍 ) to “Active Opening, Effective Management” (積極開放有效管理 )}

\section{3a. Taiwan before the policy change: rapid growth, limited FDI in China ${ }^{7}$}

In 1949, Chiang Kai-Shek's Chinese Nationalist Party (often known in the West as the Kuo Min Tang, or KMT) lost the Chinese Civil War to Mao Zedong's Chinese Communist Party and fled to Taiwan with about two million KMT loyalists. There, the KMT set up the Republic of China (ROC) government and claimed that this ROC government was the sole legitimate government of the whole of China. The Chinese Communist Party (CCP) declared that Taiwan was nothing more than a rebellious province, and that the center of the true China remained in Beijing. This set up political tensions between Taiwan and China that remain to this day and that sharply constrained economic interactions across the Taiwan Strait for decades.

The KMT's rule over Taiwan was initially politically repressive and authoritarian, but the economic policies it adopted ushered in a long boom that lasted nearly a half century, transforming the island's economy and dramatically raising living standards (Wade 1990). A gradual liberalization of Taiwan's political system after the death of Chiang Kai-Shek led to full democracy during the presidency of Lee Teng-Hui in the 1990s. These political shifts coincided with accelerating structural change in the island's economy. After decades of assiduous imitation of foreign technology, Taiwan's increasingly sophisticated manufacturers emerged as innovators in their own right. Taiwanese firms' international patenting took off in the late 1980s and grew rapidly through the 2000s, with a strong focus on the patent classes associated with electronics and information technology. By the mid-1990s, Taiwanese firms had emerged as some of the world's leading manufacturers of semiconductors and computer components.

While Taiwanese President Lee Teng-Hui continued to liberalize Taiwan's political regime, he also placed limits on economic ties with China, fearing that too much economic engagement could provide the mainland government with powerful economic leverage over Taiwan's key industries. In 1996, these regulations were codified in the so-called “no haste, be patient" (戒急用忍) policy. These regulations established a US\$50 million limit on any single investment project in China; any firm that wished to invest over this limit had to be specially approved. In addition, according to this policy, any Taiwanese firm had to limit investments in the mainland to 20-30 percent of its total foreign investment and 20 percent of its investment in Taiwan. A firm's total investment in China could not exceed 40 percent of its net worth. The policy also restricted investments in certain key sectors, including the high-tech sector (for instance, the semiconductor industry was completely banned). Taiwanese firms were prohibited from investing in major infrastructure projects on the mainland and from setting up high-tech research and development facilities. ${ }^{8}$

\footnotetext{
${ }^{7}$ For more detail about Taiwan before the controversial presidency of Chen Shui-Bian, see Chase, Pollpeter, and Mulvenon (2004) and Yang (2010).

${ }^{8}$ In reality, this policy was not totally effective in stopping the flow of capital to China; some investment slipped in through intermediaries like the Cayman Islands and Hong Kong. However, there were some high-profile instances of major companies and individual executives being fined for illegal investment in mainland China before the policy change (for example: UMC,
} 


\section{3b. Policy change under Chen Shui-Bian: "Active Opening, Effective Management",}

In the mid-1990s, Lee Teng-Hui ushered in constitutional changes that allowed for the direct election of the president. He won the first of these elections himself in a historic vote widely regarded by international observers as free and fair. ${ }^{10}$ The constitutional changes also placed term limits on Taiwanese presidents - limits Lee honored by allowing another KMT candidate to run for the office in 2000. In the 2000 election, however, democracy activist and longtime dissident Chen Shui-Bian won the presidency, an unexpected outcome for most observers. Chen's Democratic Progressive Party (DPP) had never won a presidential election in Taiwan before; in fact, he "won" the 2000 election with only $39 \%$ of the vote. Facing a legislature still controlled by the KMT and a business community skeptical of his candidacy, Chen Shui-Bian sought to build support for his new administration by taking a much more conciliatory approach to economic relations with the mainland than his predecessor. This approach, under the premise of "integration theory," was reiterated in a series of speeches over his first term. ${ }^{11}$ In addition to the desire to build an internal coalition that would support his nascent administration, Chen also wanted to secure Taiwan's admission into the World Trade Organization (WTO), which would require the adoption of more liberal policies on trade and investment.

In November 2001 the government formally announced the replacement of the "no haste, be patient" policy with the “active opening and effective management" (積極開放有效管理) policy. ${ }^{12}$ As part of the policy, the investment ceiling of US $\$ 50$ million on individual investments was removed, and all projects with a value of less than US\$20 million were automatically approved. The most important change of the new policy for our purposes was the removal of $122 \mathrm{high}$-tech products from the list of "prohibited categories," including laptops, mobile phones, digital optical drives, computer hardware and software, communication products, and consumer electronics. ${ }^{13}$

The new regime continued to subject mainland investment by Taiwanese firms to a number of regulations and restrictions. Any single investment project over US\$20 million still had to go through a special review system. The US\$50 million ceiling on individual investments was replaced by an annual ceiling on total corporate investment in the mainland. The ban on investment by Taiwan's semiconductor industry ${ }^{14}$ was initially retained, but gradually relaxed over the next several years. Remaining restrictions notwithstanding, the rules regulating the offshoring of production to the mainland were substantially reduced as a result of this policy change, stimulating a rapid increase in the amount of offshoring to

SMIC, Robert Tsao, Richard Chang, Tsai Juei-chen, Tsai Kuan-ming), indicating that the regime was not toothless. In short, the policy restrictions constrained - but did not entirely halt - FDI in China.

${ }^{9}$ For more detail about Taiwan under Chen Shui Bian's controversial presidency, see Wang (2002); Tung (2005); Tanner (2007); J. J.-F. Yang 2010; and Chen (2003).

${ }^{10}$ The mainland government responded to this vote with ominous warnings, missile tests, and military exercises. The U.S. government was so concerned by the threats emanating from the mainland regime of Jiang Zemin that President Bill Clinton ordered a U.S. Navy carrier task force to enter the Taiwan Strait - long regarded by China as territorial waters - as an unmistakable expression of support for Taiwan.

${ }^{11}$ See his [English version] inaugural speech http://www.mac.gov.tw/ct.asp?xItem $=50894 \& \mathrm{ctNode}=5913 \& \mathrm{mp}=3 \& \mathrm{xq}$ xCat $=2000$ and Cross-Century Remarks [English version] http://www.mac.gov.tw/ct.asp?xItem $=50875 \& \mathrm{ctNode}=5913 \& \mathrm{mp}=3 \& \mathrm{xq} \_\mathrm{xCat}=2001$

12 The Chen government also made other changes to cross-strait economic ties, but we focus on the active opening and effective management policy as the most relevant for our empirical setting. In January 2001, the Three Mini Links (小三通) policy was enacted, legalizing direct trade, postal service, and travel between Quemoy (Kinmen) and Matzu in Taiwan, and the adjacent ports of Fuzhou and Xiamen in China, for the first time since the Chinese Civil War. Then, President Chen established the Economic Development Advisory Committee (EDAC or 經發會) to discuss ways to stimulate Taiwan's economy and plan future economic development. Cross-Straits economic relations were one of five key areas of discussion.

${ }^{13}$ The complete list of products, identified by their HS code, is in the appendix.

${ }^{14}$ For more information about the semiconductor industry's move to mainland China, see (Klaus, 2003; C. Yang and Hung, 2003) 
China. ${ }^{15}$ We exploit the differential effect of this new set of policies on different products. Products that were moved from the "prohibited" to "allowed" categories became much less burdensome to offshore.

On the other side of the Taiwan Strait, China's formal entry into the WTO in late 2001 constituted a second coincidental policy shock that further increased Taiwanese firms' interest in investing in the mainland. We acknowledge this coincidence, but do not believe it seriously undermines our empirical strategy. While mainland China's WTO-mandated opening to foreign trade and investment varied across major industry groups, our sample of firms are all based in one sector (electronics). As such, the China "WTO" shock most likely impacted all our firms and products in a similar way. We maintain that the Taiwanese policy shift induced a change in the ability to offshore that varied across products within firms, and that this product-level variation can be used to shed light on the impact of offshoring on innovation.

\section{3c. Taiwanese offshoring after reform}

As we have already acknowledged, the pre-2001 restrictions did not completely eliminate FDI in China by Taiwanese firms, even in "prohibited" categories. Some investment took place via offshore financial centers such as Hong Kong or the Cayman islands. Nevertheless, Taiwanese firms were taking a significant risk in violating explicit government investment bans, and this limited the scope, scale, and nature of FDI on the mainland. Once Chen Shui-Bian's administration formally relaxed these restrictions, investment by Taiwanese firms surged. Between 2000 and 2004, officially recorded annual flows of outbound FDI from Taiwan to the mainland nearly tripled. By 2011, annual flows were five times greater than in 2000 (Ministry of Economic Affairs, 2016).

A large fraction of this FDI was vertical in nature; Taiwanese firms sought to use their Chinese subsidiaries as export platforms from which to serve the global market (Branstetter and Lardy, 2008). While Taiwan's imports from China grew rapidly after 2001, Taiwan's exports to the mainland grew even faster, reflecting, in part, the provision of parts and components to their mainland subsidiaries. Official statistics from Taiwan, taken from Tanner (2007) and plotted in Figure 2, provide evidence supporting this characterization of Cross-Straits trade. We can see that there was an increase in trade between China and Taiwan after 2001, and we can see that Taiwan's trade surplus with the mainland grew rapidly, even as Taiwan's imports from China also grew. Thus, Taiwan's "China shock" was quite different from the trade shocks visited upon the United States and Western Europe, whose manufacturers ran large and rapidly growing trade deficits with China.

Our firm and product level offshoring data is described in more detail in the next section, but it includes customs data, detailing all exports leaving China between 2000 and 2011 by firm. This means that we can observe whether there was an increase in exporting from Taiwanese subsidiaries in mainland China over this time period. Figure 3, constructed from our dataset, demonstrates that there is a striking increase in the total value of exports from our sample firms' subsidiaries in mainland China.

\section{3d. The Taiwanese Electronics Industry}

Over the course of the 1980s and 1990s, Taiwan became one of the world's largest producers of electronics. For example, in 2008, 92.5 percent of laptops and motherboards sold on the world market were manufactured by Taiwanese companies. ${ }^{16}$ Taiwan's electronics companies are also quite innovative;

\footnotetext{
15 The new framework introduced by the Chen Administration continued to influence Cross-Straits trade even after Chen left office in 2008. His successor, KMT candidate Ma Ying-Jeou, also sought to expand Taiwanese trade and investment with the mainland, and eventually concluded the so-called Economic Cooperation Framework Agreement (ECFA) with mainland China, but this had relatively little impact on Taiwan's electronics industry over our sample period.
}

${ }^{16}$ Institute for Information Industry (III), 2009 Conference Series on the Development Trend of the World Information and Telecommunication Industry - ICT Day, Taipei, III, MIC, 25 November 2008. 
Taiwan has been the number one recipient of USPTO patents on a per-GDP basis since $1993 .{ }^{17}$ But the sector differs in two important ways from electronics sectors in other parts of Asia. First, the firm size distribution in Taiwan includes more small and medium-sized enterprises (SMEs) and fewer giant firms, although Taiwanese giants, such as TSMC and Foxconn/Hon Hai, have emerged. Second, most of these companies were OEM (original equipment manufacturer) and/or ODM (original design manufacturer) contractors with American or Japanese multinationals. In 2020, five of the top 10 OEM electronics manufacturers in the world by revenue were Taiwanese companies (Foxconn, Pegatron, Wistron, New Kinpo, and ASE), and all of the top ten ODM electronics manufacturers were Taiwanese. As a consequence, these firms were using their Chinese manufacturing sites to produce for the global market; their FDI there was vertical in nature, as described in earlier sections.

\section{Data Sources}

One of the major contributions of this paper is the matching of multiple databases, at both the product and firm level, such that we can measure the impact of the offshoring of particular products, by particular firms, on the innovations in technologies directly associated with that product. This section describes that data construction process in detail. Figure 4 provides a diagram summarizing of the matching process.

\section{4a. Identifying Taiwanese firm sample}

We start by compiling a list of 823 Taiwanese electronics firms from the Taiwanese Stock Exchange under the category of electronics (電子工業). ${ }^{18}$ These were condensed into 792 firms, as several pairs of firms turned out to be affiliated and some firms did not exist in $2000^{19}$. We link Taiwanese parent firms to their USPTO patents so that we can measure how their patenting changed after the policy shock. Of the 792 parent firms, 711 had data on R\&D expenditures. The sales data set contains annual data for total nominal revenue between 1999 and 2013. ${ }^{20}$

\section{4b. $\quad$ Patent data}

In the paper, we use United States Patent and Trademark Office (USPTO) patent grants as an indicator of innovative output for our sample firms. The use of patent data is essential, because without it, we would have no way of allocating recorded R\&D expenditures to individual products. However, through the detailed patent classes assigned to patented inventions, we can link the innovation outcomes in particular technological domains to the products offshored by our sample firms. While a long literature exploits patents as measures of technological activity, many papers have indicated that the value distribution of patented inventions is highly skewed (Harhoff et al. 1999; Harhoff, Scherer, and Vopel 2002; Schankerman and Pakes 1986). Prior research has shown that more valuable patents tend to be patented abroad as well as at home(Jaffe and Trajtenberg 2002; Squicciarini, Dernis, and Criscuolo 2013). ${ }^{21}$ It is

\footnotetext{
${ }^{17}$ Cato Institute. 'Patent Tigers' and Global Innovation.

${ }^{18} \mathrm{http}: / /$ mops.twse.com.tw/mops/web/t51sb01

${ }^{19}$ Combined firms: Wistron NeWeb Corp and Wistron Corp; Hon Hai and Foxconn; BenQ and Qisda; Lite-on companies; Pegatron and Asus; Hannstar companies; Arima companies; Chunghwa companies; Compal companies; Inventec companies; Nan Ya companies; Quanta companies; PCHome companies. Firms that did not exist in 2000: ADATA, Edison-Opto, MStar Semiconductor, Chimei Innolux, and Nuvoton.

${ }^{20}$ Unfortunately, neither R\&D data nor sales data are broken down by product.

${ }^{21}$ Prior research and press accounts show that, in the aggregate, Taiwanese electronics firms are enthusiastic users of the U.S. patent system and tend to patent their more valuable inventions there with high frequency (Ellis, 2014).
} 
also the case that "triadic" patents ${ }^{22}$ are of the highest quality (Dernis and Khan 2004). Therefore, use of data on Taiwanese firms' U.S. patents will tend to capture more valuable inventions than those granted solely by the Taiwan Intellectual Property Office (TIPO). Prior research confirms that more valuable inventions are more highly cited (Hall, Jaffe, and Trajtenberg 2001), and in robustness checks, we will weight Taiwanese firms' U.S. patents by the number of forward citations they receive. We obtained data on all utility patents granted by the USPTO between 1976 and 2017 and matched 88,526 patents to 490 of the 792 firms by name, using a time-intensive, manual screening procedure that ensured no misspelled or alternatively written firm names were missed. The data are constructed from the August 2017 release of the PatentsView Database ${ }^{23}$. The patent data contain information on patent number, all assignee names, all assignee codes, grant year, application year, forward citations, and IPC codes.

In addition to measuring the level of innovative output with patent counts, we also measure the nature of innovative output by utilizing a methodology pioneered by Ganglmair, Robinson, and Seeligson (2020), who generously shared their classification data, to define patents as either process or product patents using the text found in patent claims. Complete details of their methodology can be found in their working paper (Ganglmair et al. 2020), but the general idea is that patents are classified based on the language of the claims. Since lawyers write patent claims in a standardized language, and they are written in very different ways for a process or product, the authors can exploit the different grammatical structures and keywords in each patent claim to identify whether it is a process or product claim. Examples of a product versus a process claim are found in Table 1. There are then three separate ways to define a patent as a process patent, based on the associated claims. These are as follows: (1) if at least $50 \%$ of the associated claims are process claims, (2) if the first claim is a process claim, and (3) if any of the associated claims are process claims.

\section{4c. $\quad$ Chinese customs data}

In order to link parent companies in Taiwan to their subsidiaries in mainland China, we then collected a list of 2,887 mainland Chinese subsidiaries founded between 1996 and 2008 that match to 664 of the 792 Taiwanese parent firms. These were found by checking each parent company website for information on their subsidiaries in mainland China and by checking the Taiwan Stock Exchange's Market Observation Post System (MOPS) ${ }^{24}$ which provides the official annual reports of all publicly listed companies in Taiwan. Those Chinese subsidiaries were then matched to export data in the mainland China customs dataset (中国海关进出口统计数据), which has also been used by Manova and Zhang (2012) and many other researchers. We extracted all exports originating from the Chinese subsidiaries of Taiwanese parent firms between 2000 and 2011. We match exports to 1,011 subsidiaries (and 331 parent firms), again using a careful manual screening to ensure no alternatively written subsidiary names were missed. We constructed a concordance across the different versions of the HS codes used in different years of the customs database (1996, 2002, and 2007). These data contain information on subsidiary name and ID, year of export, HS code, value, quantity, price, unit, and destination country.

Through the combination of these data, we capture the increase in offshoring induced by the Chen Administration's relaxation of outbound FDI restrictions. The combined data, which is both granular and rich in detail, come with significant advantages and disadvantages, and it is important that we be clear about both. After linking these customs data to the mainland subsidiaries of our Taiwanese firms, we can observe the inception and expansion of exports of particular products by the mainland subsidiaries of particular Taiwanese firms. We assume that this expansion of exports from mainland subsidiaries comes

\footnotetext{
${ }^{22}$ Patents applied for in the Japanese Patent Office (JPO), European Patent Office (EPO) and USPTO

${ }^{23}$ www.patentsview.org Patentsview is supported by the Office of the Chief Economist in the US Patent and Trademark Office, and is a collaboration between USPTO, USDA, the Center for the Science of Science and Innovation Policy, New York

University, the University of California at Berkeley, Twin Arch Technologies, and Periscopic.

${ }^{24}$ http://mops.twse.com.tw/mops/web/index
} 
at the expense of production of the same product by the same firm on Taiwan. Contemporary press accounts and other sources confirm that, in many cases, export expansion by Chinese subsidiaries really did reflect a shift of export-oriented production from Taiwan to China. However, we necessarily measure this production shifting with caution, because we have no way of directly observing the cessation of production of particular products by the Taiwanese parent. ${ }^{25}$ We also have no way of breaking down the domestic sales of these mainland subsidiaries by product. If Taiwanese firms are exporting to Chinese customers from factories in Taiwan, and then replacing these exports with production on the mainland, none of which is exported outside of China, we will miss this offshoring entirely. ${ }^{26}$ These challenges imply that we measure offshoring with a certain degree of noise, potentially leading to a downward bias in our regression estimates. To the extent that Taiwanese firms offshore production to sites other than China, our measure will fail to capture that. ${ }^{27} \mathrm{We}$ also fail to capture the offshoring of production by Taiwanese firms to unaffiliated domestic Chinese manufacturers rather than their own affiliates. ${ }^{28}$ However, since our instrumental variables strategy relies on the measurement of offshoring induced by the Chen Administration's reform of FDI policy, and that reform was specific to FDI in China, these omissions do not necessarily undermine our empirical strategy. Finally, and perhaps most significantly, our Chinese export data are not available before 2000. This means we have very limited data on offshoring prior to the policy shock, and we possess no practical means of controlling for the existence of "pre-trends" in offshoring that might be present in advance of our policy shock.

\section{4d. Linking customs data to patent data}

The last stage of our data construction is the linkage of the customs data to the patent data. Patents are organized using the International Patent Classification (IPC) system while the customs data uses an industry classification system called Harmonized System (HS) codes. The difficulty in matching them stems from the fact that the two classification systems are motivated by different objectives. The IPC system is intended to allow patent examiners to identify the novel technical features of the invention while industry systems like the Harmonized System are intended to disaggregate traded products according to their form and function. Since goods in very different categories can use the same underlying technologies, this makes construction of a concordance from IPC codes to HS codes extremely difficult. As a result, most past efforts in the literature to link patent classes to industry codes or HS codes have either been highly aggregated or have relied on old concordances whose usefulness has been undermined by rapid technological change in key domains (Schmoch, Laville, and Patel 2003; Verspagen, Moergastel, and Slabbers 1994).

However, the methodology introduced by Lybbert and Zolas (2014), using keyword generators and text mining algorithms, allows us to generate more disaggregated concordances between IPC patent classes and the HS codes in the customs data. This approach is called the Algorithmic Links with Probabilities (ALP) approach and we follow the same methodology used in the original paper here, but with HS codes instead of SITC and ISIC codes. The broad approach is as follows: First, we generate keywords from the HS classification descriptions that are robust to standard misspelling issues, relevant to the economic category, and should retrieve specific patents. This initial set is also expanded to include relevant synonyms using WIPO's PATENTSCOPE, and then manually inspected and refined. Next, we data mine

\footnotetext{
${ }^{25}$ We can measure the total value of our Taiwanese firms' sales, but we cannot break those sales down by product.

${ }^{26}$ We have no way of breaking down the domestic sales of our firms' mainland subsidiaries by product. However, in the context of the Taiwanese-Chinese relationship, our focus on Taiwanese firms' exports from their Chinese subsidiaries is defensible. As Rosen and Wang (2011) and Branstetter and Lardy (2008) document, Taiwanese firms investing in China have intensively used China as an export base.

${ }^{27}$ Industry-level data reveal that China was by far the most important host country for Taiwanese electronics firms' FDI over our sample period.

${ }^{28}$ Industry sources assert that most Taiwanese production shifting to China occurred via their own affiliates.
} 
patent abstracts and titles in the EPO and WIPO's PATSTAT database using the keywords we just generated and generate a list of patents that matched the search. We then compile a frequency of IPC classes that matches to each industry. We reweight these results in a way that minimizes Type I errors and factors in both the raw frequencies and the specificity of each technology class (or how frequently an IPC subclass appears in the PATSTAT database). These distributions create linkages from patents to economic data and vice versa, and can then be used for industry-level analyses of the relationships between patent classes and industry codes. An example is shown in Figure 5. After linking patents and exported products, we have 669 unique HS-6 digit product codes indexing patents and/or exports.

\section{4e. $\quad$ Aggregating product groups}

We aggregate product codes using K-means clustering. To define technologically proximate patenting industries, we cluster our 669 product categories using various $K$-means clustering algorithms based on certain criteria found in each of the products. The criteria used to generate our clusters include yearly patent output for all 669 product categories (in 1000's) from 2000-2011 based on the 2-digit IPC technology weights from Lybbert and Zolas $(2014)^{29}$, yearly exports (in billions of dollars) from 20002011 and a binary indicator for whether or not the policy change affected the product category (1/0). Our $K$-means clustering algorithm considers all of these criteria in determining into which clusters to place each of the product codes.

To generate clusters, we first calculate a dissimilarity matrix across each of the available criteria. To calculate the dissimilarity matrix and to ensure our results are robust, we utilize three separate distance calculations for each criterion. We utilize two of the most frequently used methods for generating distances (Euclidean ${ }^{30}$ and Canberra ${ }^{31}$ ), and an additional method that was developed specifically for use with a mixture of continuous and binary data $\left(\right.$ Gower $\left.^{32}\right)$. Our preferred methodology relies on the Gower algorithm, but our results are robust to the alternative clustering techniques.

${ }^{29}$ We use 2-digit IPCs to cluster rather than the more disaggregate 4-digit IPCs, as the more disaggregate technology weights have too little overlap across industries, resulting in very few, tiny clusters.

${ }^{30}$ Euclidean Distance: This is typically the default dissimilarity measure, used primarily for continuous data that sums up the squared differences for each criterion between each of the product codes.

$$
\left\{\sum_{i=1}^{I}\left(x_{k i}-x_{j i}\right)^{2}\right\}^{1 / 2}
$$

${ }^{31}$ Canberra Distance: This is another commonly used measure for continuous data, that takes on a value between 0 and $I$ (number of criteria that is being considered). It is sensitive to small changes near zero, which may help in weighting our distance measures and controlling for selection. The formula is given by:

$$
\sum_{i=1}^{I} \frac{\left|x_{k i}-x_{j i}\right|}{\left|x_{k i}\right|+\left|x_{j i}\right|}
$$

${ }^{32}$ Gower Distance: This algorithm can be used for continuous and binary data. It is somewhat similar to the Canberra measure for continuous data, but it utilizes a different weighting scheme for the differences. Because our data consists of both continuous and binary measures, this will be our primary algorithm, with the other algorithms used as robustness checks. The formula is given by:

For binary variables:

$$
d_{i j v}=\left\{\begin{array}{l}
0 \text { if } x_{i v}=x_{j v} \\
1 \text { otherwise }
\end{array}\right.
$$


One crucial factor is to define the number of clusters into which we would like to categorize our 669 product categories. To determine the optimal number of clusters, we attempt to minimize the withincluster sum of squares (WSS) based on the number of clusters. In doing so, we use the "elbow method," which computes the within-cluster sum of squares for a different value of $k$ for each of the $k$-means clustering algorithms listed above. We perform this for up to 50 clusters and plot the results for the Gower distance algorithm in Figure 6.

The "elbow method" relies on identifying the inflection point where the within-cluster sum of squares flattens out as additional clusters are added. From Figure 6, we see that this occurs between $k=15$ and $k=$ 20. Including more than 20 clusters provides little benefit in terms of further disaggregating the product categories and will create more noise as products will be arbitrarily separated based on the criteria we have listed above. However, providing fewer than 15 clusters leads to relatively high amounts of dissimilarity across the products within each cluster. We complete our clustering by using $K$-means and random $K$-centering (the starting point for calculating the distance from our criteria is randomly chosen) based on the aforementioned algorithms. The significant aggregation of patenting and exporting data described in this section raises the concern that our empirical results are an artifact of the particular aggregation procedure we employed. We aggregate up to 16 clusters using the Gower distance measure as our baseline, but we include robustness checks obtained using the other clustering measures in the Appendix. Violin plots of the raw data, also provided in the Appendix, reveal that the changes in offshoring (measured by export data) and patenting documented by our regression analyses of aggregated data are clearly visible in the raw data. ${ }^{33}$

\section{4f. $\quad$ Final sample}

Over the course of this matching process, we lose a number of firms; only 483 of the original 792 firms do at least some patenting or offshoring to China. This sample attrition is not random as there are systematic differences between firms that patent and offshore and those that do not. However, the remaining firms are the ones that are the most economically significant for Taiwan as the majority of excluded firms tend to be smaller, marginal producers. This sample attrition implies that we are measuring the average treatment effect only for multinational firms who do at least some patenting or exporting from China.

There are multiple ways in which we can define our sample, depending on how we treat observations in years where there are no matched patent applications and/or no exports listed for that firm-product. In our base sample, we include a firm-product cluster in all years if there was either patenting or offshoring in that firm-product cluster at some point during our time period. We thus allow for firm entry into and exit from both/either offshoring and patenting. We include regressions based on other sample definitions in the Appendix.

Table 2 shows the summary statistics for our data.

\section{Empirical Methodology and Results}

\footnotetext{
For continuous variables:$$
d_{i j v}=\frac{\left|x_{i v}-x_{j v}\right|}{\left\{\max _{k} x_{k v}-\min _{k} x_{k v}\right\}}
$$

${ }^{33}$ We thank Steve Yeaple for suggesting the robustness check provided by plots of the raw data.
} 


\section{5a. Baseline Regression Results: Measuring the First-Order, Within-Category Effect of Offshoring on Levels of Patenting}

The core question this section seeks to answer is: when Taiwanese firms moved the manufacturing of certain product categories to China, what happened to the quantity of patenting in the product categories that were offshored?

To answer this question, we start with a naïve OLS long-differences model that exploits the correlation between offshoring and patenting within firms and categories, and over time: ${ }^{34}$

$$
\ln \left(\text { Pat }_{i j t}\right)-\ln \left(\text { Pat }_{i j t=2000}\right)=\beta_{0}+\beta_{1}\left[\ln \left(O f f_{i j t}\right)-\ln \left(\text { of } f_{i j t=2000}\right)\right]+\Delta \epsilon_{i j t}
$$

where $i$ indexes the firm, $j$ indexes the product category, and $t$ indexes time in years. Innovation is proxied by patent counts ("Pat"), and offshoring ("Off') is proxied by the stock of measured exports from Chinese subsidiaries. Patents are indexed by application year ${ }^{35}$ while exports are indexed by year of export. We use a long-differencing model to remove any fixed effects for firms or product categories rather than a fixed effects model due to data constraints; we only observe one year before the policy shock occurs. We take each difference at the product category-firm level between a post-policy year (20032011) and a pre-policy year (2000). All standard errors are clustered at the firm level. ${ }^{36}$

We present coefficient estimates from an OLS specification as a baseline. Table 3 reports the results, which reveal a small, positive, statistically significant correlation between offshoring and patenting within a firm and product category that appears to persist across long differences of varying length. However, these results are subject to a number of identification concerns, including the presence of time-varying unobservable demand shocks that raise both offshoring and innovation. Imagine a successful Taiwanese firm that confronts rapidly growing demand for some subset of its products in advanced country markets. In order to expand production of these products, it may establish subsidiaries in China that can produce these products on a larger scale (and at lower cost). At the same time, the firm will seek to increase its research effort in the technologies underlying these successful products, and the results of that effort will show up as increased patenting in the classes linked to these products. We are therefore concerned about an upward bias in the OLS regression results.

To address this concern, we use a 2SLS strategy that exploits the policy shock described in Section III. As noted in that section, a new party came to power in Taiwan in 2000, and in 2001 they lifted offshoring restrictions on 122 product categories. This presents us with a source of product category-level variation; different categories were affected differentially by the policy shock. We divide product categories into two bins: categories that were directly impacted by the policy change, and categories that were unaffected (so that they either continued to be banned or continued to be approved). Although we have acknowledged evidence of limited illegal offshoring of some of these "banned" products prior to 2001, we interpret the policy change as an exogenous shock for firms wishing to offshore in those categories. We create an indicator variable to divide the two product categories and use this as our instrument. The baseline category is product categories unaffected by the policy change. ${ }^{37}$

\footnotetext{
${ }^{34}$ There are zeros in our data, so in order to use natural logs we add one to all observations.

${ }^{35}$ To better reflect the date that the innovation actually occurs, we use the application date for granted patents rather than the grant date.

${ }^{36}$ There are too few product groupings to cluster standard errors at the product level; Angrist and Pischke (2009) note that clustering standard errors when there are fewer than 42 clusters introduces the risk of bias. Therefore, in our main specifications, we do not cluster our standard errors at the product level. However, we do later show robustness checks that show our results are robust to product-clustered standard errors.

${ }^{37}$ As the reader will see, the phrase "unaffected by the policy change" refers to the first-order impact of the change in offshoring policy. To the extent that firms respond to the exogenous decline in offshoring costs in part of their portfolio by reallocating
} 
In the first stage, we regress the logged differenced cumulated flow (or "stock") of exports on our created indicator variable:

$$
\Delta \ln \left(O f f_{i j t}\right)=\alpha_{0}+\alpha_{1} \text { Affected } \text { ijt }_{i}+\varepsilon_{i j t}
$$

In the second stage, we use the predicted differenced export stock from stage one in the second stage regression, again using long differences:

$$
\left.\Delta \ln \left(P a t_{i j t}\right)=\beta_{0}+\beta_{1} \Delta \ln \widehat{\left(O f f_{l j t}\right.}\right)+u_{i j t}
$$

For this instrument to be valid, our instrument needs to be highly correlated with the potentially endogenous variable. We can measure this directly by looking at the F test of excluded instruments from the first stage results, reported in each 2SLS regression table; these tests clearly show that our instrument is strongly correlated with exporting. We must also assume that the product categories and firms that were impacted by the policy shock were not systematically more or less technologically dynamic than the ones that were unaffected. This is tantamount to assuming that, whatever technological opportunity shocks might have been affecting our sample firms, there were no systematic differences in the incidence and direction of these shocks between affected and unaffected product categories. Provided this assumption holds, our exogenous policy shift only affects patenting through changes in offshoring and is unrelated to time-varying unobservable factors like product-specific demand and technology shocks.

A close examination of the details of the policy shift provides grounds for believing that this assumption is reasonable. The text describing the investment restrictions that were retained by the Chen Administration emphasizes international conventions prohibiting trade in certain goods, weapons-related technologies, and investment in mainland infrastructure. These would not appear to be systematically related to important positive or negative technological opportunity shocks impacting Taiwanese electronics firms. ${ }^{38}$ The 122 policy categories that were liberalized in 2001 are revealed, upon close inspection, to be a mix of both high-tech and low-tech products, but, if anything, the list of formerlyprohibited-but-now-permitted categories seems biased in the direction of high-tech products with significant underlying technological opportunity for further innovation, including laptops, mobile phones, digital optical drives, and computer hardware and software. ${ }^{39}$ The products affected by the FDI regime change would appear to be more likely, rather than less likely, to benefit from positive technological opportunity shocks after the policy shift, possibly biasing us in the direction of finding a positive relationship between offshoring and innovation. The fact that our 2SLS regressions consistently indicate a

\footnotetext{
assets and effort to other parts of their portfolio, there could be second order effects, even for product categories for which offshoring regulations did not change. Most sensible models of firm behavior would allow for the possibility of this kind of reallocation, and we will find evidence of it later in the paper.

${ }^{38}$ For decades, Taiwan has heavily relied on weapons provided by the United States for its national defense. In contrast to Israel, Russia, or, increasingly, mainland China, Taiwanese firms are not considered to be innovators in weapons-related technologies. And, for obvious reasons, innovation in weapons-related technologies is systematically less likely to be patented than innovation in other domains.

${ }^{39}$ However, we must exercise a degree of caution regarding our treatment of the semiconductor industry. In contrast to computer hardware, laptops, and digital optical drives, semiconductors were not fully liberalized in 2001. Instead, liberalization in this sector proceeded gradually, over the next several years, in a manner that appeared to involve a considerable degree of discretion on the part of the Chen Administration. Press accounts suggest that this approach was motivated by a desire to keep the most technologically dynamic parts of Taiwan's semiconductor industry - presumably the parts facing the most significant technological opportunities - on Taiwan. In earlier versions of the paper, we considered the semiconductor industry to be "unaffected" by the FDI regime change, because only a few firms were allowed to invest in China. That classification decision could raise concerns about the validity of our identifying assumptions, given the eventual size of the semiconductor industry and its relatively strong performance in terms of patent growth over time. To deal with these concerns, we exclude the semiconductor sector (defined as HS 8541-8542 and 8486) from our specifications.
} 
negative relationship is therefore reassuring. To deal more systematically with the possibility that some of our other firm-product "clusters" are becoming more technologically dynamic than others even before the FDI policy shift, we also rerun regressions explicitly controlling for "pre-trends" in the product level patenting data. Our results are qualitatively robust to the inclusion of these controls as well, shown in the Appendix. A graph of average USPTO patenting trends in the US for affected vs unaffected product categories, shown in the Appendix, also is supportive of the view that the 122 policy categories that were liberalized were not systematically less technologically dynamic than the ones that were unaffected. Finally, we note that our IV approach passed a series of over-identification and endogeneity tests. ${ }^{40}$

Table 4 shows the baseline 2SLS results, which suggest that our concerns about a potential upward-bias in the OLS regressions due to demand shocks or other time-varying unobservables may have been wellfounded. When we instrument for offshoring using the policy shock, instead of finding a positive effect as in the OLS regressions, we instead find a negative and statistically significant effect on patenting levels. The results show that a $100 \%$ increase in the stock of exporting causes a roughly $2-4 \%$ decline in patenting for a firm-category pair, relative to the amount of patenting growth that would have happened without offshoring. Thus, the first order impact of offshoring on the level of within-category patenting appears to be negative.

We also examine forward citation-weighted ${ }^{41}$ patent counts to identify whether the negative effect on patenting is stronger for patents with higher citations. Table 5 presents results of the 2SLS regression on citation-weighted patent counts and shows slightly larger stronger effects for the citation-weighted results, suggesting that the negative effect is not being driven solely by a decline in marginal or incremental innovation.

\section{5b. Robustness Checks}

Our first robustness check, in Table 6, shows results from the subsample of firms who both offshore and patent. The results presented in these tables are consistent with the earlier regressions, showing a negative within-category effect of offshoring on innovation, even for the subset of firms who are active in both offshoring and patenting.

Patents are a relatively rare event and their distribution has a long right tail. We dealt with this in the previous specifications by applying OLS but transforming patents to be $\ln$ (patents +1 ). Adding one to the observations can - in some situations - create bias, so we also utilized a count data model - IV Poisson that is well-equipped to deal with these kinds of distributional challenges. In these specifications, we move the base patent value to the right-hand side of the equation, since count data models cannot be run on dependent variables with negative values. Results are shown in Table 7, and demonstrate that our results are not driven by any issues with our transformation; they still show a negative effect of offshoring on innovation. Note that the coefficients are much smaller because patent counts and export value are no longer logged, so the interpretation is different. These results are shown with product-clustered standard errors as a further robustness check.

The Appendix contains further robustness checks, briefly described here. We control for patent pre-trends by product cluster, both globally and in Taiwan, and continue to find a negative and statistically significant effect. We also include a 2SLS specification where we apply the inverse hyperbolic sine transformation (IHS) to both patenting and offshoring value in lieu of logging both variables. The IHS

\footnotetext{
${ }^{40}$ This includes all the standard tests that accompany the ivreg2 command in Stata: Kleibergen-Pap, Anderson-Rubin Wald, Stock-Wright, and Hausman.

${ }^{41}$ We use the total count of forward citations divided by (2012-current year) to address potential citation truncation concerns.
} 
transformation is a useful alternative specification because it approximates the natural logarithm of the variable but allows zero valued observations. The results are also robust to excluding Hon Hai (also known as Foxconn) from the regressions. Finally, although our primary product aggregation method, as described in the data section, used a Gower clustering algorithm, we also used the Canberra clustering algorithm and the Euclidean clustering algorithm as robustness checks; results are robust to these alternative clustering methodologies, as well as to different numbers of clusters.

The results are robust to these different specifications, suggesting that the significant increase in offshoring by Taiwanese firms to China in response to President Chen's 2001 policy significantly slowed the growth in patenting by Taiwanese firms in the affected product categories relative to the growth in patenting that would have happened had manufacturing of those products remained in Taiwan. These robustness checks appear to confirm that the first-order, within-category effect of offshoring on patenting and innovation is negative. These results line up quite nicely with the Autor et al. (2016) results that Chinese import competition negatively affected innovation. However, as we will see, the story is far more complicated than that.

\section{5c. Measuring the Within-Category Effect of Offshoring on the Nature of Patenting}

In this section, we examine the hypothesis of whether offshoring production changes the nature of innovation through its impact on the incentives facing the offshoring firm. The theoretical prediction of the direction of the effect on the nature of innovation is ambiguous. One argument is that a shift in the firm's innovation strategy may occur if the geographic separation of manufacturing from R\&D reduces innovative capability through the reduction of tacit knowledge flows. Such a decline could hit process and product innovation equally. Alternatively, we might logically expect that it is in the domain of process innovation that the link between $R \& D$ and manufacturing is the strongest, as suggested in work by Pisano and Shih (2009). A decline in R\&D capability associated with offshoring might result in an overall decline in $R \& D$ output (as reflected by fewer patents), and a disproportionate decline in process patents.

A different view, which we associate with the work of Erica Fuchs, suggests that offshoring does not curtail R\&D capabilities so much as it shifts $R \& D$ incentives. To review this argument, consider that our Taiwanese firms are offering their prospective customers a set of products, each of which represents a tradeoff between price and performance. They could potentially sell more by lowering the cost or enhancing the performance or both. While process innovation could potentially impact performance or cost, economists often think of process innovation as focused primarily on reducing the cost of an existing good with a relatively fixed level of performance (Klepper 1996). Alternatively, Taiwanese firms could increase sales and profits by enhancing product performance, which could come primarily through the replacement of old products with new, better products offering a higher level of performance (i.e., product innovation). If offshoring is not an option, firms are constrained to rely on some mix of product and process innovation to increase the appeal of their product portfolio, and both kinds of innovation require costly effort on the part of the firm's engineers.

Now, imagine that offshoring becomes an option for this product category. Suddenly, the firm can achieve the goal of cost reduction by offshoring production rather than relying solely on process innovation. Offshoring production to a lower cost site might offer the firm the opportunity to achieve large scale cost reductions at a relatively low resource cost. Moreover, once the product is moved to the lower cost site, additional process innovations that take advantage of the lower cost factors available in the new site could yield further cost declines that might have been impossible to engineer if the product remained in the home country. In short, moving a relatively mature product to a lower-cost location could, by reducing costs, give it a new lease on life, enabling the firm to postpone the replacement of the product with something new. That, in turn, allows the firm to avoid or at least defer costly investments in risky product innovation. 
However, offshoring production may not enhance the appeal of every product. For some products, better performance is the only viable pathway to higher sales, and that can only be achieved by (costly and risky) product innovation. If the product portfolio of the firm in question has both kinds of products, then an exogenous shock that lowers the cost of offshoring for some products could have the following chain of effects. For the newly offshored products, firms find that the large cost declines allow them to offer customers lower prices at a relatively low resource cost. The new factor costs associated with the new site open up new possibilities for cost reduction. Pursuing those opportunities through additional process innovation further lowers the price, making refinement of the processes associated with the current product more attractive than replacing the (now less costly) product with something new. In short, this third view implies a reduction in overall R\&D effort (as evidenced by fewer patents) and an especially sharp reduction in product innovation. Here the decline in patenting arises not because of a rise in costs or a decline in capabilities, but a shift in incentives.

This line of reasoning suggests that $R \& D$ resource savings may occur, as the optimal level of overall $\mathrm{R} \& \mathrm{D}$ investment devoted to the now-offshored product declines. These $\mathrm{R} \& \mathrm{D}$ resources could be plausibly reallocated to other products, where the option of offshoring is not appropriate or profitable. In a later section, we will look for evidence of this reallocation into other product categories. For now, we focus solely on the within-category impact of offshoring on the nature of innovation.

Our 2SLS regression strategy can provide interesting evidence on this point. Tables 8 and 9 provide the results from Equation (3), but with an important change: the dependent variable is the logged count of process patents in Table 8 and the logged count of product patents in Table 9. The results support our hypothesis: innovation in the product categories that were offshored shifted significantly towards process innovation and away from product innovation. The negative effect on innovation in the categories that were offshored came primarily from a reduction in product patents, while process patents in the offshored categories actually may have increased. Movement of production to China appears to have increased the relative attractiveness of investing in refinement of established technologies - at the expense of further investment in riskier emerging technologies.

We dig deeper into these results by categorizing each of our 16 product-technology categories as either "more product-oriented" or "more process-oriented" in terms of patenting in $2000^{42}$ (prior to the shock) and examine how the nature of innovation associated with these categories changes after the offshoring shock. The optimal mix of product and process innovation is likely to vary across these categories due to technological factors and market conditions. But the larger question is whether offshoring changed this mix within categories.

Table 10 shows the results from Equation (3), but for the subsample of "more product-oriented" categories. This table shows that the negative patenting results of Section 5a are driven largely by a reduction in patenting in categories that were more product-innovation oriented before the policy shock. The coefficients in Table 10 ("more product-oriented" offshored categories) are significantly larger than those of Table 4 (all offshored categories). In contrast, the coefficients in Table 11 ("more processoriented" offshored categories) are either not statistically significant or slightly positive.

The results suggest that when a Taiwanese firm offshores a product category to China in response to the policy shock of 2001, the scale of the ensuing reduction in associated patenting was dependent on whether they were engaged in more process or product innovation in that category prior to offshoring. If the firm was doing more product innovation in that category before they moved production to China, the innovation decline was steeper as the firm ceased performing product innovation in that category and

\footnotetext{
${ }^{42}$ We simply divide the product categories by the share of total patenting in 2000 that was categorized as a process vs product patent.
} 
shifted towards process innovation. If, however, they were doing more process innovation in that category at that time, innovation in that category was mostly unaffected or may have increased. If offshoring changes incentives but not capabilities, this is exactly what we would expect to see in the data.

\section{5d. Measuring the Second-Order, Cross-Category Effect of Offshoring on Levels of Patenting}

In this section, we provide evidence of R\&D resource reallocation within a firm's innovation portfolio towards innovation in non-offshored product categories. We explicitly refer to these effects as secondorder, and we expect their magnitudes to be lower than the first-order impacts estimated in section $5 a$.

In the previous sections, we observed that after offshoring, Taiwanese firms reduce their patenting in technologies associated with the product categories impacted by the policy shock, and that they reorient their patenting towards process innovations. These changes may offer the offshoring firms the opportunity to reallocate the engineering talent they had accumulated within the firm to different tasks. Not all firms will pursue these opportunities, but some may, in part because engineering talent is highly specialized and may represent a kind of "stranded asset" within the firm (Bloom et al., 2019). If the engineers who were doing product innovation in the offshored categories are no longer needed there, then they are likely to be reallocated to other product categories that are technologically proximate to the ones exogenously offshored. This focus on technological proximity is justified by the specialized nature of technologies and inherent differences across classes so that the accumulated skill and experience is likely to be most productive if it is applied in a technologically proximate domain. Following a similar line of logic, if the reallocated engineers were focused on product engineering before, it is likely that we will find them similarly engaged in product innovation after the reallocation.

To measure this effect, we perform a 2SLS regression specification similar to the specification in section $5 a$, where the first stage looks identical to the previous:

$$
\Delta \ln \left(o f f_{i j t}\right)=\alpha_{0}+\alpha_{1} \text { Affected } d_{i j t}+\varepsilon_{i j t}
$$

But where the second stage's dependent variable is the weighted sum of patents in technologically proximate field $k$ :

$$
\left.\Delta \ln \left(\text { Pat }_{i k t}\right)=\beta_{0}+\beta_{1} \Delta \ln \overline{(O f f}_{l j t}\right)+u_{i j t}
$$

The weighted sum of patents in product categories $k$ are technologically proximate to those in offshored product category $j$, where the weight is the inverse of the relevant distance measure, measuring the technological distance between product $k$ and $i^{43}$. This weight is intended to measure how technologically proximate category $k$ is to category $j$. The idea is that when firm $i$ offshores category $j$ to China, they might reallocate resources to other parts of their portfolio, and particularly to those parts of their portfolio technologically closest to category $j$. The distance between category $k$ and category $j$ represents how technologically proximate the two categories are. If indeed it is true that a firm - after offshoring some product categories - switches its innovative focus and resources to closely-related product categories (category $k$ ), then we would expect $\beta_{1}>0$. Table 12 shows exactly that. While the coefficients are statistically different from zero, they are smaller than the first-order effects estimated in section 5a. This makes sense as not all resources can be perfectly reallocated, and it may be that some are lost in transition.

\footnotetext{
${ }^{43}$ Our baseline distance measure is Gower, as described earlier.
} 
These results on their own are suggestive of the existence of a positive innovative effect on other parts of a firm's portfolio, but a closer examination of the nature of the innovative impact reveals more evidence in support of this argument.

\section{5e. Measuring the Cross-Category Effect of Offshoring on the Nature of Patenting}

We argued in the previous section that innovative resources saved after product categories were offshored were then reallocated towards technologically proximate categories unaffected by the policy change. If the second-order, cross-category increase in the level of patenting that we observe in these technologically proximate categories was truly driven by reallocation, then we expect that increase to be driven by a shift towards product innovation. We find exactly this effect, shown in the 2SLS regression results of Tables 13 and 14. In categories technologically proximate to the offshored categories and within the same firm, the second-order, cross-category increase in patenting came entirely from an increase in product patenting (Table 13), with no evidence of any statistically significant increase in process patenting (Table 14).

\section{Discussion}

Our results reveal a complicated but interesting pattern surrounding the impact of offshoring on innovation. We find that offshoring production reduces innovation - especially product innovation - in the product categories that are offshored, which supports the theory proposed by Erica Fuchs and her coauthors (Fuchs 2014; Yang, Nugent, and Fuchs 2016; Fuchs and Kirchain 2010a). These effects appear to be driven more by shifts in innovation incentives rather than declines in innovative capabilities. However, this is not the full story. A closer look suggests that after offshoring, firms redirect their innovative efforts away from the offshored category and towards product innovations in technologically proximate categories. More generally, our results are consistent with the idea that offshoring is a way for firms to maximize the benefits of low-cost labor through process innovation abroad, while increasing the options for exploring new product innovation at home.

Interviews with senior managers of several of the Taiwanese firms ${ }^{44}$ provide further support for this view. One firm described how they offshored in order to keep costs down so that they can innovate in the newest areas, using the phrase "[we] built the chicken in China, but we have to feed it with new products developed in Taiwan". Another firm noted that after offshoring to China, they shifted their core values and specialization to product design and away from process innovation in manufacturing. These stories are consistent with what we see in the data, illustrated in Figure 7, which show aggregate growth in product innovation in categories where offshoring costs remained high, while simultaneously showing a decline in product innovation in categories where offshoring costs dropped considerably after the 2001 policy change.

Our results highlight the importance of thinking about innovation as a means to an end, rather than an end in itself. Firms innovate to reduce costs of existing technologies and/or to create new technologies. Moving production to a lower cost location is an alternative way of lowering the costs of an existing technology. When Taiwanese firms were permitted to offshore, their reactions set off a complex series of shifts in their innovation strategies affecting both the level and nature of innovation with differential effects across different product areas. It is only through observing the firm's complete innovation portfolio that we were able to find these changes.

\footnotetext{
${ }^{44}$ These interviews took place by the authors in December 2018
} 


\section{Conclusions}

Over the past several decades, there has been a dramatic shift in the global distribution of manufacturing. Driven by opportunities for cost reductions, many multinationals have offshored much of their production to lower-wage countries while continuing to undertake skill-intensive activities such as marketing, strategy, and R\&D in the home country. Experts have disputed the impact of this shift on firms' innovative capacity for decades. On the one hand, economic theory suggests gains resulting from this move. However, other strands of the literature argue that separating the manufacturing and $R \& D$ functions of a firm can undermine a firm's innovative capacity by reducing the potential for "learning-bydoing" and creating challenges for knowledge transfer and feedback between R\&D and production. Despite longstanding interest in resolving this theoretical ambiguity through empirical investigation, the endogeneity of offshoring and innovation - at the firm, industry, and country level - has made it difficult for researchers to come to definitive conclusions.

In this paper, we shed light on this debate by studying the Taiwanese electronics industry and by leveraging a policy shock that lifted restrictions on offshoring to China. We find robust evidence from 2SLS regressions that an exogenous rise in offshoring reduced innovation in patent classes associated with the products that were offshored. In addition, we find that this reduction came primarily from a reduction in product innovation. In contrast, process innovation appears to increase after offshoring. These results are less consistent with the notion that separating R\&D and manufacturing undermines the firm's innovation capabilities, but far more more supportive of the notion that offshoring shifts innovation incentives.

We also find evidence of a second-order, cross-category positive effect of offshoring on the levels of innovation in technologically proximate patents. We argue that part of this increase is driven by the reallocation of innovative resources saved through offshoring, and that interpretation is strengthened by the observation that the second-order, cross-category increase in the level of patenting is driven entirely by an increase product innovation, not process innovation. This evidence is directionally consistent with the economic theory predicting a reallocation of resources towards new product varieties after offshoring, although the mechanism we identify is somewhat different. More generally, our combined results are consistent with the idea that offshoring is a way for firms to maximize the benefits of low-cost labor (and other factors) through process innovation abroad, while increasing the options for exploring new product innovation at home.

Caution is warranted in generalizing from the experience of Taiwanese electronics firms to innovative industries around the world. However, it appears likely that offshoring would lead to a similarly complex response in other contexts as well. These changes in the nature and direction of innovation induced by offshoring may be as important as the induced changes in the level of innovation. The methods introduced in this paper provide ways of undertaking a more comprehensive approach to measurement of all these changes, and they may constitute a useful foundation upon which future scholarship can build. 


\section{References}

Angrist, Joshua D. and Jorn-Steffen Pischke. 2009. Mostly Harmless Econometrics: An Empiricist's Companion. Princeton and Oxford: Princeton University Press.

Autor, David H., David Dorn, Gordon H. Hanson, Gary P. Pisano, and Pian Shu. 2020. "Foreign Competition and Domestic Innovation: Evidence from US Patents." American Economic Review: Insights 2(3): 357-74

Bernard, Andrew B., Teresa C. Fort, Valerie Smeets, and Frederic Warzynski. 2020. Heterogeneous Globalization: Offshoring and Reorganization.

Bloom, Nicholas, Mirko Draca, and John Van Reenen. 2016. "Trade Induced Technical Change? The Impact of Chinese Imports on Innovation, IT and Productivity." Review of Economic Studies 83:87117.

Bøler, Esther Ann, Andreas Moxnes, and Karen Helene Ulltveit-Moe. 2015. "R\&D, International Sourcing, and the Joint Impact on Firm Performance." American Economic Review 105(12):370439.

Branstetter, Lee. 2006. "Is Foreign Direct Investment a Channel of Knowledge Spillovers? Evidence from Japan's FDI in the United States." Journal of International Economics 68:325-44.

Branstetter, Lee, Jong-Rong Chen, Britta Glennon, Chih-Hai Yang, and Nikolas J. Zolas. 2015. "Does Offshoring Manufacturing Harm Innovation in the Home Country? Evidence from Taiwan." Working Paper 1-34.

Branstetter, Lee and Nicholas Lardy. 2008. "China's Embrace of Globalization." in China's Economic Transition: Origins, Mechanisms, and Consequences. Cambridge University Press.

Branstetter, Lee and Kamal Saggi. 2009. "Intellectual Property Rights, Foreign Direct Investment and Industrial Development.” The Economic Journal 121(2000):1161-91.

Campbell, Douglas and Karsten Mau. n.d. "On 'Trade Induced Technical Change? The Impact of Chinese Imports on Innovation, IT and Productivity."” Review of Economic Studies.

Chase, Michael S., Kevin L. Pollpeter, and James C. Mulvenon. 2004. Shanghaied? The Economic and Political Implications of the Flow of Information Technology and Investment Across the Taiwan Strait.

Chen, Ezra N. H. 2003. "The Economic Integration on Taiwan and China and Its Implications for CrossStrait Relations." (July):46.

Clark, Kim B., W. B. Chew, Takahiro Fujimoto, John Meyer, and F. M. Scherer. 1987. "Product in Development World Auto the Industry." Brookings Papers on Economic Activity 1987(3):729-81.

Cohen, Stephen S. and John Zysman. 1987. "Why Manufacturing Matters: The Myth of the PostIndustrial Economy.” California Management Review 29(3):9-26.

Cohen, Wesley M. and Steven Klepper. 1996. "Firm Size and the Nature of Innovation within Industries: The Case of Process and Product R\&D." The Review of Economics and Statistics 78(2):232-43.

Dernis, Hélène and Mosahid Khan. 2004. Triadic Patent Families Methodology.

Dunning, John H. 1998. "Location and the Multinational Enterprise: A Neglected Factor?” Journal of International Business Studies 29:45-66.

Florida, Richard. 1996. "The Globalization of R\&D: Results of a Survey of Foreign-Affiliated R\&D 
Laboratories in the USA.” Research Policy 26:85-103.

Fort, Teresa C., Wolfgang Keller, Peter K. Schott, Stephen Yeaple, and Nikolas J. Zolas. 2020. CoLocation of Production and Innovation: Evidence from the United States.

Fuchs, E. and R. Kirchain. 2010. "Design for Location? The Impact of Manufacturing Offshore on Technology Competitiveness in the Optoelectronics Industry.” Management Science 56(12):232349.

Fuchs, Erica R. H. 2014. "Global Manufacturing and the Future of Technology." Science (New York, N.Y.) 345:519-20.

Ganglmair, Bernhard, W. Keith Robinson, and Michael Seeligson. 2020. Patent Claims: New Data and Stylized Facts.

Glass, Amy Jocelyn and Kamal Saggi. 2001. "Innovation and Wage Effects of International Outsourcing." European Economic Review 45:67-86.

Griffith, Rachel, Rupert Harrison, and John Van Reenen. 2006. "How Special Is the Special Relationship? Using the Impact of U.S. R\&D Spillovers on U.K. Firms as a Test of Technology Sourcing." The American Economic Review 96(5):1859-75.

Grossman, Gene M. and Elhanan Helpman. 1991a. "Quality Ladders and Product Cycles." The Quarterly Journal of Economics 106(2):557.

Grossman, Gene M. and Elhanan Helpman. 1991b. "Quality Ladders in the Theory of Growth." The Review of Economic Studies 58(1):43.

Grossman, Gene M. and Esteban Rossi-Hansberg. 2008. "Trading Tasks: A Simple Theory of Offshoring.” American Economic Review 98:1978-97.

Hall, Bronwyn H., Adam B. Jaffe, and Manuel Trajtenberg. 2001. "The NBER Patent Citations Data File: Lessons, Insights and Methodological Tools.” NBER Working Paper \#8498 (3094):1-74.

Harhoff, Dietmar, Francis Narin, F. M. Scherer, and Katrin Vopel. 1999. "Citation Frequency and the Value of Patented Inventions." The Review of Economics and Statistics 81(3):511-15.

Harhoff, Dietmar, F. M. Scherer, and Katrin Vopel. 2002. "Citations, Family Size, Opposition, and the Value of Patent Rights.” Research Policy 1596:1-21.

Helpman, Elhanan. 1993. "Innovation, Imitation, and Intellectual Property Rights." Econometrica 61(6):1247-80.

Jaffe, Adam B. and Manuel Trajtenberg. 2002. Patents, Citations, and Innovations: A Window on the Knowledge Economy. MIT Press.

Ketokivi, Mikko and Jyrki Ali-Yrkkö. 2009. "Unbundling R\&D and Manufacturing: Postindustrial Myth or Economic Reality?” Review of Policy Research 26:35-54.

Klaus, Michael. 2003. "Red Chips: Implications of the Semiconductor Industry's Relocation to China." Asian Affairs: An American Review 29(4):237-53.

Klepper, Steven. 1996. "Entry, Exit, Growth, and Innovation over the Product Life Cycle." The American Economic Review 86(3):562-83.

Kline, Stephen J. and Nathan Rosenberg. 1986. "An Overview of Innovation." European Journal of Innovation Management 38:275-305. 
Lai, Edwin L. 1998. "International Intellectual Property Rights Protection and the Rate of Product Innovation." Journal of Development Economics 55:133-53.

Lybbert, Travis J. and Nikolas J. Zolas. 2014. "Getting Patents and Economic Data to Speak to Each Other: An 'Algorithmic Links with Probabilities' Approach for Joint Analyses of Patenting and Economic Activity.” Research Policy 43(3):530-42.

Manova, Kalina and Zhiwei Zhang. 2012. "Export Prices across Firms and Destinations." Quarterly Journal of Economics 127(1):379-436.

McKendrick, David, Richard F. Doner, and Stephan Haggard. 2000. From Silicon Valley to Singapore: Location and Competitive Advantage in the Hard Disk Drive Industry. Stanford Business Books.

Oviatt, Benjamin M. and Patricia Phillips McDougall. 1994. "Toward a Theory of International New Ventures.” Journal of International Business Studies 25(1):45-64.

Pisano, Gary P. and Willy C. Shih. 2009. "Restoring American Competitiveness." Harvard Business Review 87(July).

Rosen, Daniel H. and Zhi Wang. 2011. The Implications of China-Taiwan Economic Liberalization.

Schankerman, Mark and Ariel Pakes. 1986. "Estimates of the Value of Patent Rights in European Countries During the Post-1950 Period Author.” The Economic Journal 96(384):1052-76.

Schmoch, Ulrich, Francoise Laville, and P. Patel. 2003. "Linking Technology Areas to Industrial Sectors: Final Report to the European Commission, DG Research." Final Report to the European (November):1-25.

Schumpeter, J. A. 1939. Business Cycles: A Theoretical, Historical, and Statistical Analysis of the Capitalist Process.

Squicciarini, Mariagrazia, Hélène Dernis, and Chiara Criscuolo. 2013. "Measuring Patent Quality: Indicators of Technological and Economic Value." OECD Science, Technology and Industry Working Papers (03):70.

Tanner, Murray. 2007. Chinese Economic Coercion Against Taiwan: A Tricky Weapon to Use.

Teece, David J. 1996. "Firm Organization, Industrial Structure, and Technological Innovation." Journal of Economic Behavior and Organization 31:193-224.

Tung, Chen-yuan. 2005. "Taiwan's Cross-Strait Economic Policy and Prospects of Cross-Strait Economic Relations." Views \& Policies: Taiwan Forum 2(2):99-117.

Vernon, Raymond. 1966. "International Investment and International Trade in the Product Cycle." Quarterly Journal of Economics 80(2):190-207.

Verspagen, Bart, Ton Van Moergastel, and Maureen Slabbers. 1994. "MERIT Concordance Table : IPC ISIC (Rev. 2).” MERIT Research Memorandum (31).

Wade, Robert. 1990. Governing the Market: Economic Theory and the Role of Government in East Asian Industrialization. Princeton University Press.

Wang, Vincent Wei-cheng. 2002. "The Chen Shui-Bian Administration's Mainland Policy: Toward a Modus Vivendi or Continued Stalemate?” American Asian Review 20(3):91-124.

Yang, Chia Hsuan, Rebecca Nugent, and Erica R. H. Fuchs. 2016. "Gains from Others' Losses: Technology Trajectories and the Global Division of Firms." Research Policy 45(3):724-45. 
Yang, Chyan and Shiu-wan Hung. 2003. "Taiwan's Dilemma Across the Strait: Lifting the Ban on Semiconductor Investment in China." Asian Survey 43(4):681-96.

Yang, Jonathan Jen-Fu. 2010. Guarding the Nation against the Market: The Rise and Fall of Taiwan's "No Haste, Be Patient" Policy, 1996-2001. 
Figure 1: Offshoring and the trade-off between process and product innovation.

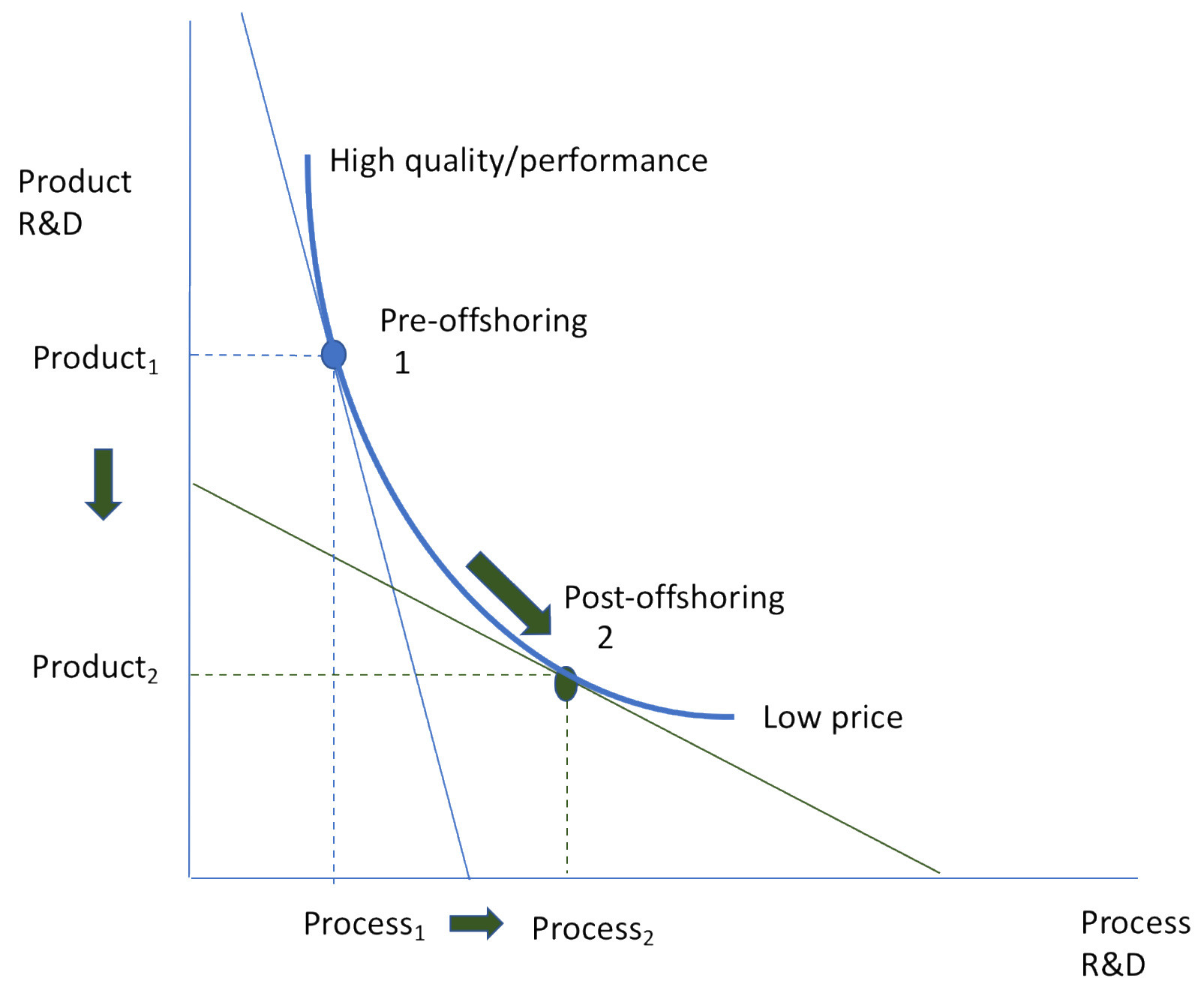

Notes: This figure illustrates how Taiwanese firms make their optimal trade-off between product and process R\&D before and after the offshoring policy shock. In the pre-offshoring equilibrium, Taiwanese firms can generate high returns by offering customers high/quality or performance (which requires substantial investment in product R\&D) or low prices (which requires investment in process R\&D and/or offshoring to a lower price location). The blue "quasi-isoquant" depicted in the figure displays the combinations of quality/performance and price discounts favored by customers. Given the initial price of achieving high quality (through product R\&D) relative to the price of achieving low prices (through process R\&D), as represented by the blue line, the initially optimal combination is at point \#1, the point of tangency between the isoquant and the line whose slope represents the relative costs of process versus product $R \& D$. When the policy shock allows offshoring to China, the relative resource cost of achieving low prices declines (inclusive of any direct offshoring costs) because the shift to a lower cost location allows a given amount of process R\&D to deliver an even greater decline in prices. The new ratio of relative R\&D prices is illustrated by the slope of the green line. The new optimum shifts to point \#2. Firms respond to this new ratio of relative prices by decreasing their level of product R\&D from "Product 1 " to "Product 2 " and increasing their level of process R\&D form "Process 1 " to "Process2." Students of international trade will recognize that this figure simply relabels a popular diagram used to describe how firms adjust their optimal mix of factors in response to a relative factor price change. The way this particular diagram is drawn, the decline in product $R \& D$ exceeds the increase in process $R \& D$ - firms are able to reach the isoquant (albeit a different point on the isoquant) at lower resource cost. This is exactly the kind of shift in $R \& D$ traced out by our measured changes in within-category patenting - overall patenting declines, and there is a relative shift toward process patents relative to product patents. 
Figure 2: Cross-Strait Trade 1990-2005

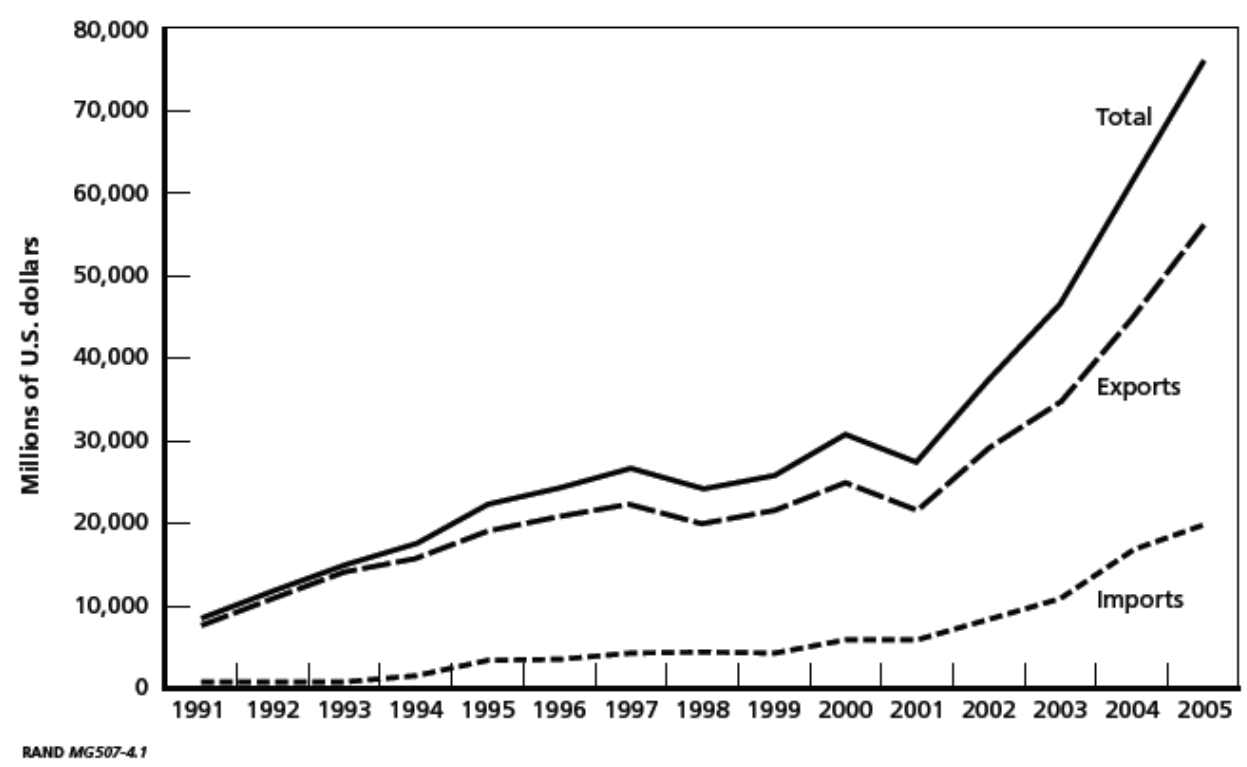

Notes: Each line shows, from top to bottom, total trade, exports, and imports between China and Taiwan in millions of U.S. dollars over time, as reported using official statistics from Taiwan. The figure is taken from Tanner (2007). 
Figure 3: Exports from Taiwanese Subsidiaries in China

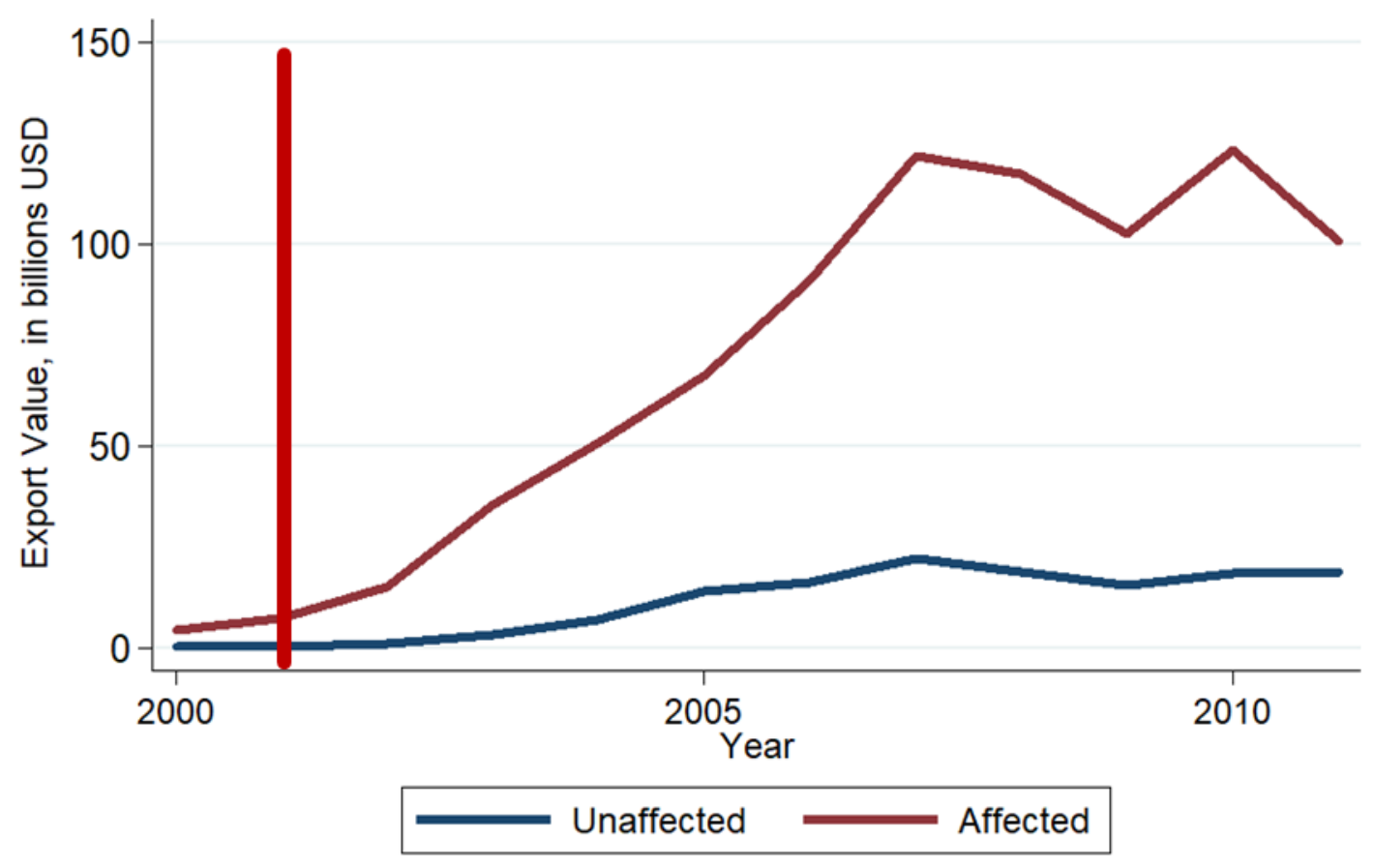

Notes: These lines show the total value of exports from the Taiwanese subsidiaries in China of the Taiwanese multinationals in our sample over time, in billions of USD. We have divided the exports into two categories: those affected by the 2001 policy change, and those unaffected by it. The red line indicates the time of the policy change. 
Figure 4: Data Summary

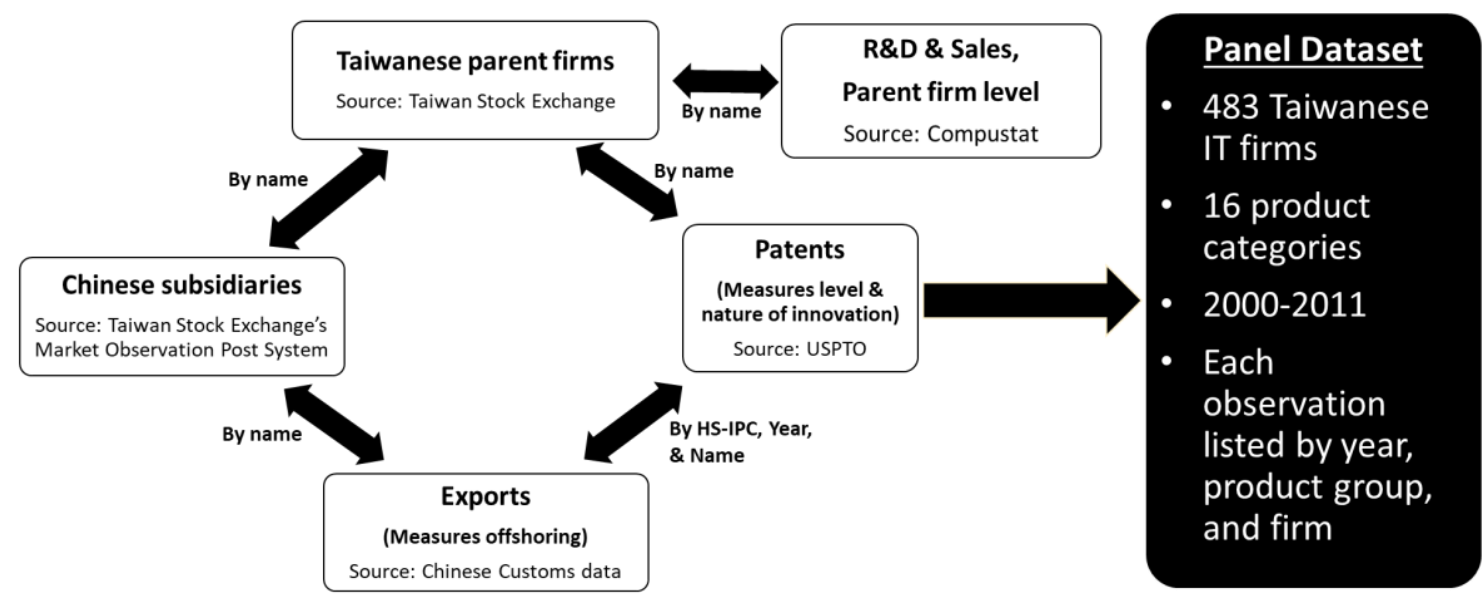

Notes: The above figure shows all the datasets and sources combined for the paper, and how they were combined. 
Figure 5: Example of IPC4-HS6 probability mapping

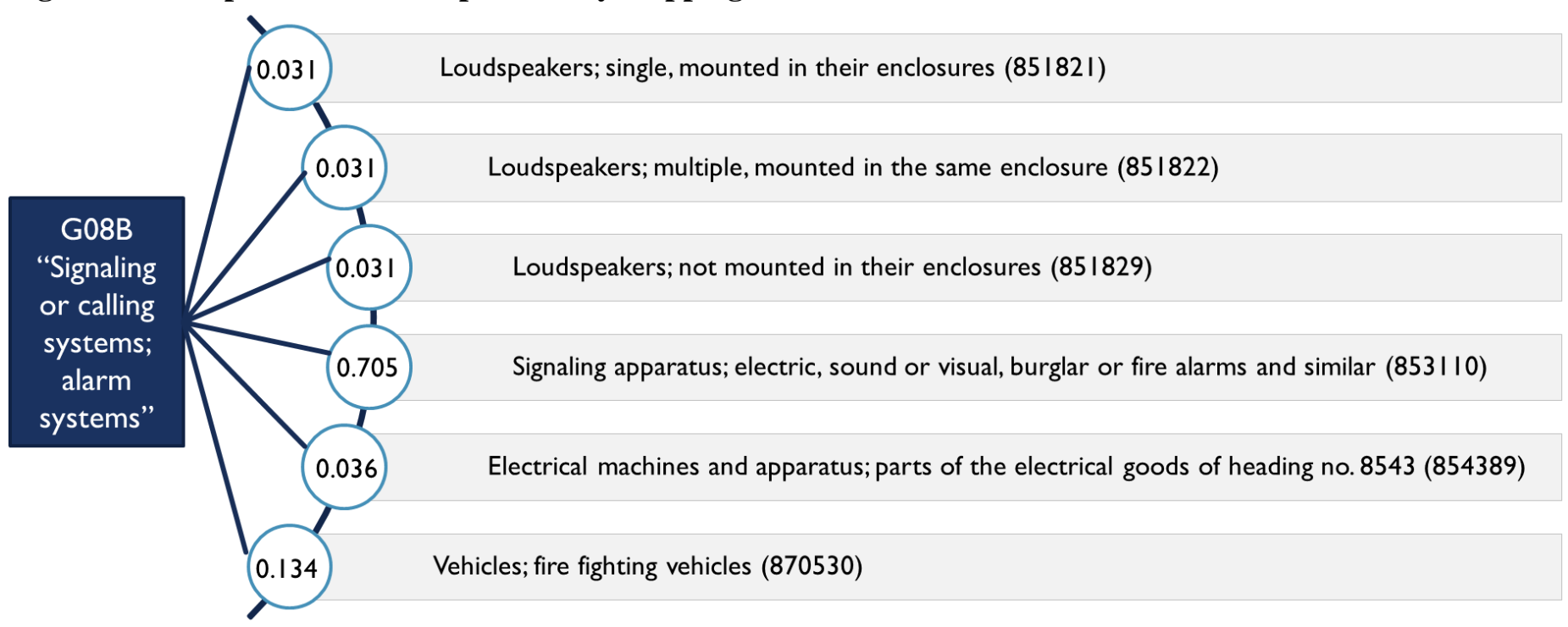


Figure 6: Elbow test to determine optimal number of clusters
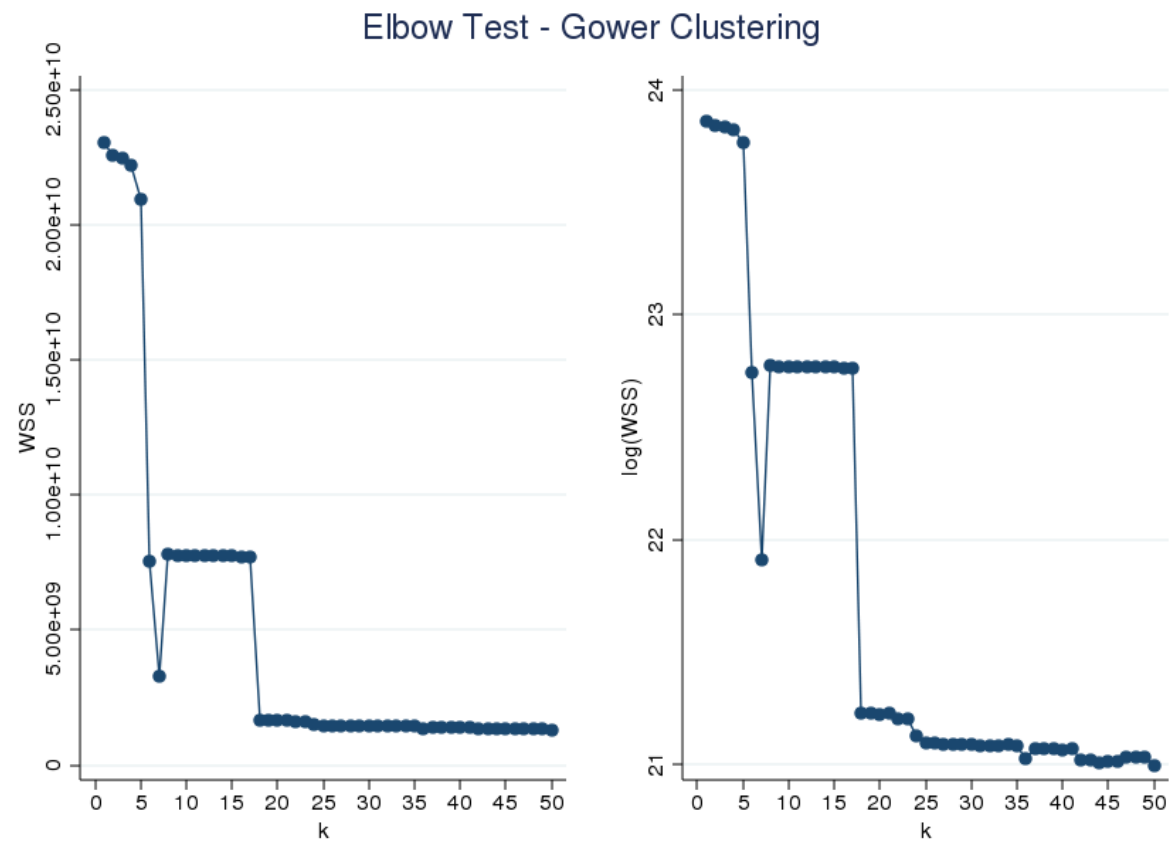

Notes: The "elbow method" tells us to identify the inflection point where the within-cluster sum of squares flattens out as additional clusters are added. From this figure, we see that this occurs between $k=15-20$. 
Figure 7: The changing patent portfolio of Taiwanese firms

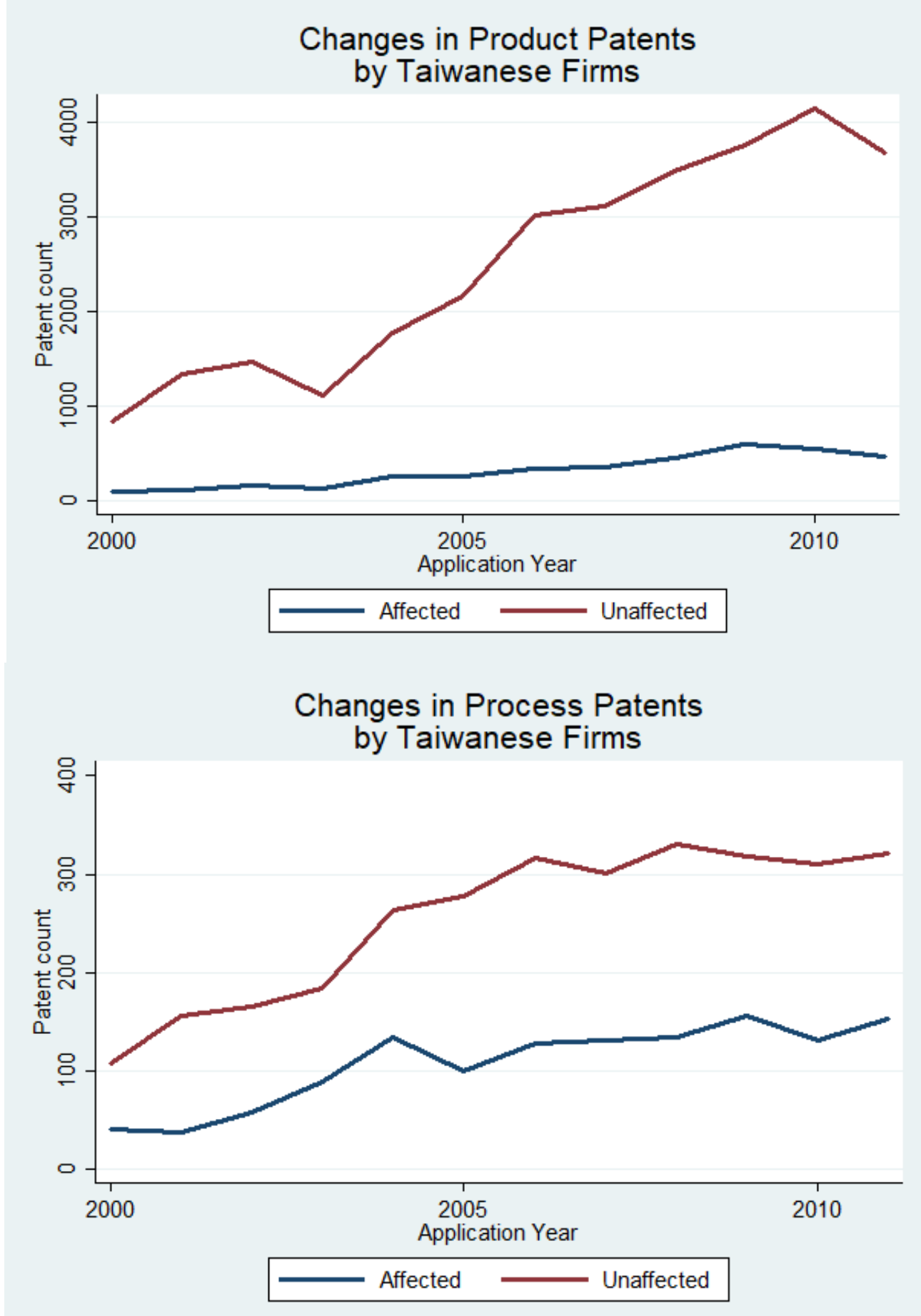




\section{Table 1: Product vs Process Claim Examples}

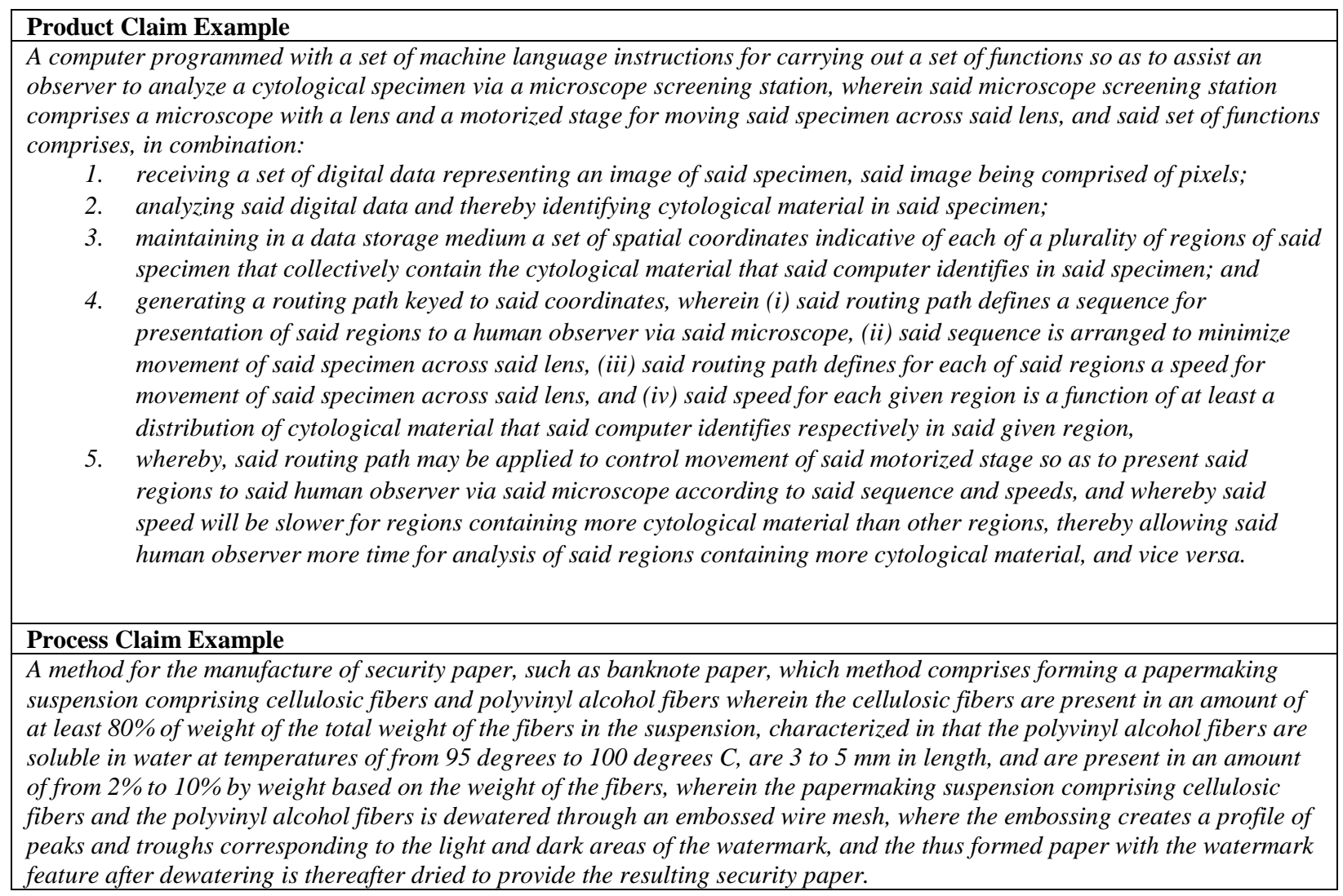

Notes: Examples of a product and a process claim from (Ganglmair et al. 2020). Analysis is both keyword-based and also utilizes grammatical structure analysis. Process claims will use words like "method" or "process" and will often have a standardized structure such as "A method of X comprising the steps of [...]". Product claims also have some keywords like "device" or "machine" but are typically less easy to classify. Process claims will typically have a series of steps, while product claims will instead use many nouns and adjectives. 
Table 2: Summary Statistics

\begin{tabular}{|c|c|c|c|c|c|}
\hline & Mean & Std Dev & Min & Max & $\mathbf{N}$ \\
\hline $\begin{array}{l}\text { Patents per firm in } \\
2000\end{array}$ & 2.51 & 21.22 & 0 & 447.64 & 483 \\
\hline $\begin{array}{l}\text { Export value per firm } \\
\text { in } 2000 \text { (USD) }\end{array}$ & $11,835,406$ & $72,251,997$ & 0 & $1,111,477,420$ & 483 \\
\hline $\begin{array}{l}\text { Patents per product } \\
\text { category in } 2000\end{array}$ & 67.44 & 135.35 & 0 & 5550.47 & 16 \\
\hline $\begin{array}{l}\text { Export value per } \\
\text { product category in } \\
2000 \text { (USD) }\end{array}$ & $317,583,382$ & $510,312,235$ & 0 & $1,860,372,422$ & 16 \\
\hline $\begin{array}{l}\text { Patents per firm- } \\
\text { product category in } \\
2000\end{array}$ & 0.33 & 5.42 & 0 & 311.63 & 3665 \\
\hline $\begin{array}{l}\text { Export value per firm- } \\
\text { product category in } \\
20000 \text { (USD) }\end{array}$ & $1,559,755$ & $18,126,895$ & 0 & $521,122,013$ & 3665 \\
\hline
\end{tabular}

Notes: This table provides some summary statistics for the two key variables in our regressions: USPTO patents by Taiwanese firms in specific product clusters, probability weighted according to their IPC-HS match, and export value by Taiwanese firms in specific product clusters in USD. 
Table 3: OLS Regression, Effect of Logged Differenced Offshoring on Logged Differenced Patent Counts

\begin{tabular}{|c|c|c|c|c|c|c|c|c|c|}
\hline & $\begin{array}{l}(1) \\
2003-0 \\
\end{array}$ & $\begin{array}{l}(2) \\
2004-0 \\
\end{array}$ & $\begin{array}{l}(3) \\
2005-0 \\
\end{array}$ & $\begin{array}{l}(4) \\
2006-0 \\
\end{array}$ & $\begin{array}{l}(5) \\
2007-0 \\
\end{array}$ & $\begin{array}{l}(6) \\
2008-0 \\
\end{array}$ & $\begin{array}{l}\mathbf{( 7 )} \\
2009-0 \\
\end{array}$ & $\begin{array}{l}(8) \\
2010-0 \\
\end{array}$ & $\begin{array}{l}(9) \\
2011-0 \\
\end{array}$ \\
\hline \multirow{2}{*}{$\begin{array}{l}\text { Change in } \\
\text { Offshoring }\end{array}$} & $0.00664 * * *$ & $0.00759 * * *$ & $0.00773 * * *$ & $0.00768 * * *$ & $0.00809 * * *$ & $0.00517^{* *} *$ & $0.00463^{*}$ & $0.00447^{*}$ & 0.00307 \\
\hline & (0.00209) & $(0.00228)$ & $(0.00228)$ & $(0.00243)$ & $(0.00231)$ & $(0.00233)$ & $(0.00253)$ & (0.00229) & $(0.00225)$ \\
\hline Constant & $\begin{array}{l}0.0225 * * \\
(0.0106)\end{array}$ & $\begin{array}{l}0.0565 * * * \\
(0.0130)\end{array}$ & $\begin{array}{l}0.0789 * * * \\
(0.0154)\end{array}$ & $\begin{array}{l}0.111 * * * \\
(0.0171)\end{array}$ & $\begin{array}{l}0.112 * * * \\
(0.0186)\end{array}$ & $\begin{array}{l}0.143 * * * \\
(0.0203)\end{array}$ & $\begin{array}{l}0.149 * * * \\
(0.0217)\end{array}$ & $\begin{array}{l}0.139 * * * \\
(0.0209)\end{array}$ & $\begin{array}{l}0.147 * * * \\
(0.0211)\end{array}$ \\
\hline Observations & 3,665 & 3,665 & 3,665 & 3,665 & 3,665 & 3,665 & 3,665 & 3,665 & 3,665 \\
\hline R-squared & 0.007 & 0.009 & 0.009 & 0.008 & 0.010 & 0.004 & 0.003 & 0.003 & 0.001 \\
\hline
\end{tabular}

Notes: The dependent variable is the long difference of the natural $\log$ of the probability-weighted patent count for a firm-product cluster between 2000 and a given year. Each column represents a different long difference, ranging from 2003 to 2011. The probability weights on the patent counts are generated by the Algorithmic Links with Probabilities approach that generates a concordance between IPC patent classes and HS codes. Offshoring is the long difference of the natural log of the value, in US dollars, of export stock from China by Taiwanese firms, between 2000 and the same given year. The specifications are OLS specifications, and firm-level cluster-robust standard errors appear in parentheses. $* * *, * *$, and $*$ denote statistical significance at the 1,5 , and 10 percent levels, respectively. 
Table 4: 2SLS Regressions, Effect of Logged Differenced Offshoring on Logged Differenced Patent Counts

\begin{tabular}{|c|c|c|c|c|c|c|c|c|c|}
\hline & $\begin{array}{c}1) \\
2003-0 \\
\end{array}$ & $\begin{array}{c}(2) \\
2004-0 \\
\end{array}$ & $\begin{array}{c}(3) \\
2005-0 \\
\end{array}$ & $\begin{array}{c}(4) \\
2006-0 \\
\end{array}$ & $\begin{array}{c}(5) \\
2007-0 \\
\end{array}$ & $\begin{array}{c}(6) \\
2008-0 \\
\end{array}$ & $\begin{array}{c}(7) \\
2009-0 \\
\end{array}$ & $\begin{array}{c}(8) \\
2010-0 \\
\end{array}$ & $\begin{array}{c}(9) \\
2011-0 \\
\end{array}$ \\
\hline \multirow{2}{*}{$\begin{array}{l}\text { Change in } \\
\text { Offshoring }\end{array}$} & 0.00132 & -0.00695 & $-0.0255 * *$ & $-0.0324 * * *$ & $-0.0241 * * *$ & $-0.0257 * * *$ & -0.00339 & -0.0139 & $-0.0232 * *$ \\
\hline & $(0.0107)$ & $(0.00906)$ & $(0.0103)$ & $(0.0117)$ & $(0.00927)$ & $(0.00979)$ & $(0.00893)$ & $(0.00939)$ & $(0.0105)$ \\
\hline Constant & $\begin{array}{c}0.0337 \\
(0.0290)\end{array}$ & $\begin{array}{c}0.0968 * * * \\
(0.0326)\end{array}$ & $\begin{array}{c}0.195 * * * \\
(0.0428)\end{array}$ & $\begin{array}{c}0.273 * * * \\
(0.0532)\end{array}$ & $\begin{array}{c}0.265^{* * * *} \\
(0.0494)\end{array}$ & $\begin{array}{c}0.304 * * * \\
(0.0564)\end{array}$ & $\begin{array}{c}0.194 * * * \\
(0.0536)\end{array}$ & $\begin{array}{c}0.247^{* * * *} \\
(0.0616)\end{array}$ & $\begin{array}{c}0.309 * * * \\
(0.0690)\end{array}$ \\
\hline Observations & 3,665 & 3,665 & 3,665 & 3,665 & 3,665 & 3,665 & 3,665 & 3,665 & 3,665 \\
\hline First stage F & 22.78 & 32.38 & 29.73 & 32.44 & 44.30 & 45.93 & 45.84 & 44.15 & 37.02 \\
\hline
\end{tabular}

Notes: The dependent variable is the long difference of the natural $\log$ of the probability-weighted patent count for a firm-product cluster between 2000 and a given year. Each column represents a different long difference, ranging from 2003 to 2011. The probability weights on the patent counts are generated by the Algorithmic Links with Probabilities approach that generates a concordance between IPC patent classes and HS codes. Offshoring is the long difference of the natural $\log$ of the value, in US dollars, of export stock from China by the same Taiwanese firms in the same product cluster, between 2000 and the same given year. The specifications are 2SLS specifications, where the instrument is a dummy variable set to one if the product cluster was affected by the 2001 policy change, and zero otherwise. Firm-level cluster-robust standard errors appear in parentheses. ***, **, and * denote statistical significance at the 1,5 , and 10 percent levels, respectively. 
Table 5: 2SLS Regressions, Effect of Logged Differenced Offshoring on Logged Differenced Forward Citation-Weighted Patent Counts

\begin{tabular}{|c|c|c|c|c|c|c|c|c|c|}
\hline & $\begin{array}{l}\text { (1) } \\
2003-0\end{array}$ & $\begin{array}{l}(2) \\
2004-0\end{array}$ & $\begin{array}{l}(3) \\
2005-0\end{array}$ & $\begin{array}{l}(4) \\
2006-0\end{array}$ & $\begin{array}{l}\text { (5) } \\
2007-0\end{array}$ & $\begin{array}{l}\text { (6) } \\
2008-0\end{array}$ & $\begin{array}{l}\text { (7) } \\
\text { 2009-0 }\end{array}$ & $\begin{array}{l}(8) \\
2010-0\end{array}$ & $\begin{array}{l}\text { (9) } \\
\text { 2011-0 }\end{array}$ \\
\hline \multirow{2}{*}{$\begin{array}{l}\text { Change in } \\
\text { Offshoring }\end{array}$} & -0.00426 & -0.0138 & $-0.0285^{* * *} *$ & $-0.0403^{* * *}$ & $-0.0287 * * *$ & $-0.0320 * * *$ & $-0.0165^{*}$ & $-0.0310 * * *$ & $-0.0553 * * *$ \\
\hline & $(0.0103)$ & $(0.00858)$ & $(0.0110)$ & $(0.0119)$ & $(0.00918)$ & $(0.0100)$ & $(0.00981)$ & $(0.0120)$ & $(0.0168)$ \\
\hline \multirow{2}{*}{ Constant } & 0.0262 & $0.0920 * * *$ & $0.176^{* * *}$ & $0.266^{* * *} *$ & $0.255^{* * *}$ & $0.317 * * *$ & $0.266^{* * *}$ & $0.379 * * *$ & $0.616^{* * *}$ \\
\hline & $(0.0270)$ & $(0.0300)$ & $(0.0443)$ & $(0.0538)$ & $(0.0490)$ & $(0.0586)$ & $(0.0608)$ & $(0.0773)$ & $(0.112)$ \\
\hline Observations & 3,665 & 3,665 & 3,665 & 3,665 & 3,665 & 3,665 & 3,665 & 3,665 & 3,665 \\
\hline First stage F & 22.78 & 32.38 & 29.73 & 32.44 & 44.30 & 45.93 & 45.84 & 44.15 & 37.02 \\
\hline
\end{tabular}

Notes: The dependent variable is the long difference of the natural $\log$ of the probability and citation-weighted patent count for a firm-product cluster between 2000 and a given year. Each column represents a different long difference, ranging from 2003 to 2011 . The probability weights on the patent counts are generated by the Algorithmic Links with Probabilities approach that generates a concordance between IPC patent classes and HS codes. To adjust for truncation, the citation weight is the average number of forward cites per year that each patent has received. Offshoring is the long difference of the natural log of the value, in US dollars, of export stock from China by the same Taiwanese firms in the same product cluster, between 2000 and the same given year. The specifications are 2SLS specifications, where the instrument is a dummy variable set to one if the product cluster was affected by the 2001 policy change, and zero otherwise. Firm-level cluster-robust standard errors appear in parentheses. ${ }^{* *},{ }^{* *}$, and $*$ denote statistical significance at the 1,5 , and 10 percent levels, respectively. 
Table 6: 2SLS Regressions, Effect of Logged Differenced Offshoring on Logged Differenced Patent Counts, for Firms that Offshore and Patent

\begin{tabular}{|c|c|c|c|c|c|c|c|c|c|}
\hline & $\begin{array}{l}\text { (1) } \\
2003-0\end{array}$ & $\begin{array}{l}(2) \\
2004-0\end{array}$ & $\begin{array}{l}(3) \\
2005-0\end{array}$ & $\begin{array}{l}(4) \\
2006-0\end{array}$ & $\begin{array}{l}(5) \\
2007-0\end{array}$ & $\begin{array}{l}(6) \\
2008-0\end{array}$ & $\begin{array}{l}(7) \\
2009-0\end{array}$ & $\begin{array}{l}(8) \\
2010-0\end{array}$ & $\begin{array}{l}(9) \\
2011-0\end{array}$ \\
\hline $\begin{array}{l}\text { Change in } \\
\text { Offshoring }\end{array}$ & -0.00651 & -0.00994 & $-0.0245^{* *}$ & $-0.0342 * * *$ & $-0.0297 * * *$ & $-0.0294 * * *$ & -0.0110 & $-0.0187 * *$ & $-0.0238 * *$ \\
\hline Constant & $\begin{array}{l}(0.0100) \\
0.0646^{*} \\
(0.0381)\end{array}$ & $\begin{array}{l}(0.00838) \\
0.130 * * * \\
(0.0430)\end{array}$ & $\begin{array}{l}(0.00954) \\
0.237 * * * \\
(0.0556)\end{array}$ & $\begin{array}{l}(0.0115) \\
0.340^{* * *} \\
(0.0718)\end{array}$ & $\begin{array}{l}(0.00943) \\
0.351 * * * \\
(0.0678)\end{array}$ & $\begin{array}{l}(0.00968) \\
0.379 * * * \\
(0.0760)\end{array}$ & $\begin{array}{l}(0.00841) \\
0.259 * * * \\
(0.0703)\end{array}$ & $\begin{array}{l}(0.00919) \\
0.317 * * * \\
(0.0827)\end{array}$ & $\begin{array}{l}(0.0103) \\
0.363 * * * \\
(0.0938)\end{array}$ \\
\hline $\begin{array}{l}\text { Observations } \\
\text { First stage F }\end{array}$ & $\begin{array}{l}2,458 \\
25.21\end{array}$ & $\begin{array}{l}2,458 \\
35.48\end{array}$ & $\begin{array}{l}2,458 \\
32.82\end{array}$ & $\begin{array}{l}2,458 \\
33.80\end{array}$ & $\begin{array}{l}2,458 \\
45.55\end{array}$ & $\begin{array}{l}2,458 \\
45.94\end{array}$ & $\begin{array}{l}2,458 \\
45.60\end{array}$ & $\begin{array}{l}2,458 \\
43.46\end{array}$ & $\begin{array}{l}2,458 \\
36.65\end{array}$ \\
\hline
\end{tabular}

Notes: The dependent variable is the long difference of the natural log of the probability-weighted patent count for a firm-product cluster between 2000 and a given year. Each column represents a different long difference, ranging from 2003 to 2011. The probability weights on the patent counts are generated by the Algorithmic Links with Probabilities approach that generates a concordance between IPC patent classes and HS codes. Offshoring is the long difference of the natural log of the value, in US dollars, of export stock from China by the same Taiwanese firms in the same product cluster, between 2000 and the same given year. The specifications are 2SLS specifications, where the instrument is a dummy variable set to one if the product cluster was affected by the 2001 policy change, and zero otherwise. The regression is performed on a subsample of Taiwanese firms who do both offshoring and patenting. Firm-level cluster-robust standard errors appear in parentheses. $* * *, * *$, and $*$ denote statistical significance at the 1,5 , and 10 percent levels, respectively. 
Table 7: IVPoisson Regressions, Effect of Differenced Offshoring on Patent Counts

\begin{tabular}{|c|c|c|c|c|c|c|c|c|c|}
\hline & $\begin{array}{c}(1) \\
2003 \\
\end{array}$ & $\begin{array}{c}(2) \\
2004 \\
\end{array}$ & $\begin{array}{c}(3) \\
2005 \\
\end{array}$ & $\begin{array}{c}(4) \\
2006 \\
\end{array}$ & $\begin{array}{c}(5) \\
2007 \\
\end{array}$ & $\begin{array}{c}(6) \\
2008 \\
\end{array}$ & $\begin{array}{c}(7) \\
2009 \\
\end{array}$ & $\begin{array}{c}(8) \\
2010 \\
\end{array}$ & $\begin{array}{c}(9) \\
2011 \\
\end{array}$ \\
\hline \multirow{2}{*}{$\begin{array}{l}\text { Change in } \\
\text { Offshoring }\end{array}$} & $-5.80 \mathrm{e}-07 * * *$ & $-2.33 \mathrm{e}-07 * * *$ & $-1.18 \mathrm{e}-07 * * *$ & $-8.62 \mathrm{e}-08 * * *$ & $-2.30 \mathrm{e}-08 * * *$ & $-1.25 \mathrm{e}-08 * * *$ & $-7.05 \mathrm{e}-09 * *$ & $-5.55 \mathrm{e}-09 * * *$ & $-3.81 \mathrm{e}-09 * * *$ \\
\hline & $(1.25 \mathrm{e}-07)$ & $(6.49 \mathrm{e}-08)$ & $(2.36 \mathrm{e}-08)$ & $(1.44 \mathrm{e}-08)$ & $(3.78 \mathrm{e}-09)$ & $(2.26 \mathrm{e}-09)$ & $(3.12 \mathrm{e}-09)$ & $(1.55 \mathrm{e}-09)$ & $(1.31 \mathrm{e}-09)$ \\
\hline \multirow{2}{*}{$\begin{array}{l}\text { Patenting in } \\
2000\end{array}$} & $0.296 * * *$ & $0.255 * * *$ & $0.258 * * *$ & $0.329 * * *$ & $0.346^{* * *}$ & $0.343 * * *$ & $0.286^{* *}$ & $0.300 * * *$ & $0.266^{* * *}$ \\
\hline & $(0.0597)$ & $(0.0657)$ & $(0.0477)$ & $(0.0516)$ & $(0.0539)$ & $(0.0589)$ & $(0.117)$ & $(0.0782)$ & $(0.0841)$ \\
\hline Constant & $\begin{array}{c}-0.962 * * * \\
(0.269)\end{array}$ & $\begin{array}{c}-0.473 \\
(0.296)\end{array}$ & $\begin{array}{c}-0.481 * \\
(0.277)\end{array}$ & $\begin{array}{c}-0.273 \\
(0.283)\end{array}$ & $\begin{array}{l}-0.268 \\
(0.315)\end{array}$ & $\begin{array}{l}-0.0746 \\
(0.325)\end{array}$ & $\begin{array}{c}0.185 \\
(0.366)\end{array}$ & $\begin{array}{l}0.0653 \\
(0.360)\end{array}$ & $\begin{array}{c}0.105 \\
(0.350)\end{array}$ \\
\hline Observations & 3,665 & 3,665 & 3,665 & 3,665 & 3,665 & 3,665 & 3,665 & 3,665 & 3,665 \\
\hline
\end{tabular}

Notes: The dependent variable is the probability-weighted patent count for a firm-product cluster in a given postpolicy year. The probability weights on the patent counts are generated by the Algorithmic Links with Probabilities approach that generates a concordance between IPC patent classes and HS codes. Offshoring_stock is the long difference of the value, in US dollars, of export stock from China by the same Taiwanese firms in the same product cluster, between 2000 and the same given year. The specifications are IVPoisson specifications, where the instrument is a dummy variable set to one if the product cluster was affected by the 2001 policy change, and zero otherwise. Product-level cluster-robust standard errors appear in parentheses. ***, **, and * denote statistical significance at the 1,5 , and 10 percent levels, respectively. 
Table 8: The Within-Category Effect of Logged Differenced Offshoring on the Nature of Patenting (Process Innovation) Table Shows Second Stage Regression Coefficients

Dependent Variable: Logged Long-Differenced Process Patents

\begin{tabular}{|c|c|c|c|c|c|c|c|c|c|}
\hline & $\begin{array}{c}(1) \\
2003-0 \\
\end{array}$ & $\begin{array}{c}(2) \\
2004-0 \\
\end{array}$ & $\begin{array}{c}3) \\
2005-0 \\
\end{array}$ & $\begin{array}{c}(4) \\
2006-0 \\
\end{array}$ & $\begin{array}{c}5) \\
2007-0 \\
\end{array}$ & $\begin{array}{c}(6) \\
2008-0 \\
\end{array}$ & $\begin{array}{c}(7) \\
2009-0 \\
\end{array}$ & $\begin{array}{c}(8) \\
2010-0 \\
\end{array}$ & $\begin{array}{c}(9) \\
2011-0 \\
\end{array}$ \\
\hline \multirow{2}{*}{$\begin{array}{l}\text { Change in } \\
\text { Offshoring }\end{array}$} & $0.0160 * *$ & 0.00950 & 0.00529 & 0.00583 & $0.0125^{* *}$ & $0.0117^{*}$ & $0.0194 * * *$ & 0.0105 & $0.0157 * *$ \\
\hline & $(0.00776)$ & $(0.00617)$ & $(0.00612)$ & $(0.00572)$ & $(0.00580)$ & $(0.00668)$ & $(0.00691)$ & $(0.00654)$ & $(0.00744)$ \\
\hline Constant & $\begin{array}{l}-0.0129 \\
(0.0166)\end{array}$ & $\begin{array}{c}0.0157 \\
(0.0164)\end{array}$ & $\begin{array}{c}0.0332 \\
(0.0219)\end{array}$ & $\begin{array}{c}0.0412 * * \\
(0.0209)\end{array}$ & $\begin{array}{l}0.00906 \\
(0.0251)\end{array}$ & $\begin{array}{c}0.0172 \\
(0.0316)\end{array}$ & $\begin{array}{l}-0.0256 \\
(0.0330)\end{array}$ & $\begin{array}{c}0.0136 \\
(0.0339)\end{array}$ & $\begin{array}{l}-0.0187 \\
(0.0404)\end{array}$ \\
\hline Observations & 3,665 & 3,665 & 3,665 & 3,665 & 3,665 & 3,665 & 3,665 & 3,665 & 3,665 \\
\hline First stage F & 22.78 & 32.38 & 29.73 & 32.44 & 44.30 & 45.93 & 45.84 & 44.15 & 37.02 \\
\hline
\end{tabular}

Notes: The dependent variable is the long difference of the natural log of the process patent count for a firm-product cluster between 2000 and a given year. Each column represents a different long difference, ranging from 2003 to 2011. Offshoring is the long difference of the natural $\log$ of the value, in US dollars, of export stock from China by the same Taiwanese firms in the same product cluster, between 2000 and the same given year. The specifications are 2SLS specifications, where the instrument is a dummy variable set to one if the product cluster was affected by the 2001 policy change, and zero otherwise. 
Table 9: The Within-Category Effect of Logged Differenced Offshoring on the Nature of Patenting (Product Innovation) Table Shows Second Stage Regression Coefficients

Dependent Variable: Logged Long-Differenced Product Patents

\begin{tabular}{|c|c|c|c|c|c|c|c|c|c|}
\hline & $\begin{array}{c}(1) \\
2003-0 \\
\end{array}$ & $\begin{array}{c}(2) \\
2004-0 \\
\end{array}$ & $\begin{array}{c}(3) \\
2005-0 \\
\end{array}$ & $\begin{array}{c}(4) \\
2006-0 \\
\end{array}$ & $\begin{array}{c}5) \\
2007-0 \\
\end{array}$ & $\begin{array}{c}(6) \\
2008-0 \\
\end{array}$ & $\begin{array}{c}7) \\
2009-0 \\
\end{array}$ & $\begin{array}{c}(8) \\
2010-0 \\
\end{array}$ & $\begin{array}{c}(9) \\
2011-0 \\
\end{array}$ \\
\hline Change in & -0.00780 & -0.0121 & $-0.0274 * * *$ & $-0.0335^{* * *}$ & $-0.0251 * * *$ & $-0.0264 * * *$ & -0.00614 & $-0.0147 *$ & $-0.0223 * *$ \\
\hline & $(0.0101)$ & $(0.00867)$ & $(0.0101)$ & (0.0111) & $(0.00891)$ & $(0.00912)$ & $(0.00808)$ & $(0.00882)$ & $(0.0100)$ \\
\hline Constant & $\begin{array}{l}0.0503^{*} \\
(0.0280)\end{array}$ & $\begin{array}{c}0.105 * * * \\
(0.0323)\end{array}$ & $\begin{array}{c}0.195 * * * \\
(0.0419)\end{array}$ & $\begin{array}{c}0.267 * * * * \\
(0.0512)\end{array}$ & $\begin{array}{c}0.255^{* * * *} \\
(0.0476)\end{array}$ & $\begin{array}{c}0.290 * * * * \\
(0.0526)\end{array}$ & $\begin{array}{c}0.184 * * * \\
(0.0495)\end{array}$ & $\begin{array}{c}0.234 * * * \\
(0.0585)\end{array}$ & $\begin{array}{c}0.283 * * * \\
(0.0667)\end{array}$ \\
\hline Observations & 3,665 & 3,665 & 3,665 & 3,665 & 3,665 & 3,665 & 3,665 & 3,665 & 3,665 \\
\hline First stage F & 22.78 & 32.38 & 29.73 & 32.44 & 44.30 & 45.93 & 45.84 & 44.15 & 37.02 \\
\hline
\end{tabular}

Notes: The dependent variable is the long difference of the natural log of the product patent count for a firm-product cluster between 2000 and a given year. Each column represents a different long difference, ranging from 2003 to 2011. Offshoring is the long difference of the natural log of the value, in US dollars, of export stock from China by the same Taiwanese firms in the same product cluster, between 2000 and the same given year. The specifications are 2SLS specifications, where the instrument is a dummy variable set to one if the product cluster was affected by the 2001 policy change, and zero otherwise. 
Table 10: The Within-Category Impact of Logged Differenced Offshoring on the Nature of Patenting (Subsample of Categories Focused on Product Innovation Before Offshoring)

Table Shows Second Stage Regression Coefficients Dependent Variable: Logged Long-Differenced Patents

\begin{tabular}{|c|c|c|c|c|c|c|c|c|c|}
\hline & $\begin{array}{c}(1) \\
2003-0 \\
\end{array}$ & $\begin{array}{c}(2) \\
2004-0\end{array}$ & $\begin{array}{c}(3) \\
2005-0 \\
\end{array}$ & $\begin{array}{c}(4) \\
2006-0 \\
\end{array}$ & $\begin{array}{c}5) \\
2007-0 \\
\end{array}$ & $\begin{array}{c}(6) \\
2008-0 \\
\end{array}$ & $\begin{array}{c}(7) \\
2009-0 \\
\end{array}$ & $\begin{array}{c}(8) \\
2010-0 \\
\end{array}$ & $\begin{array}{c}(9) \\
2011-0 \\
\end{array}$ \\
\hline \multirow{2}{*}{$\begin{array}{l}\text { Change in } \\
\text { Offshoring }\end{array}$} & -0.0224 & -0.0481 & $-0.0912 *$ & -0.142 & $-0.0717 * * *$ & $-0.0872 * * *$ & $-0.0741 * * *$ & $-0.0780 * * *$ & $-0.0960 * * *$ \\
\hline & $(0.0437)$ & $(0.0491)$ & $(0.0534)$ & $(0.0893)$ & $(0.0275)$ & $(0.0300)$ & $(0.0264)$ & $(0.0268)$ & $(0.0331)$ \\
\hline Constant & $\begin{array}{c}0.101 \\
(0.108)\end{array}$ & $\begin{array}{c}0.242 \\
(0.156)\end{array}$ & $\begin{array}{c}0.487 * * \\
(0.209)\end{array}$ & $\begin{array}{c}0.811 * * \\
(0.398)\end{array}$ & $\begin{array}{c}0.564 * * * \\
(0.146)\end{array}$ & $\begin{array}{c}0.700 * * * \\
(0.172)\end{array}$ & $\begin{array}{c}0.647 * * * \\
(0.162)\end{array}$ & $\begin{array}{c}0.685 * * * \\
(0.173)\end{array}$ & $\begin{array}{c}0.826 * * * \\
(0.220)\end{array}$ \\
\hline Observations & 2,001 & 2,001 & 2,001 & 2,001 & 2,001 & 2,001 & 2,001 & 2,001 & 2,001 \\
\hline First stage F & 1.875 & 2.706 & 4.153 & 3.329 & 12.97 & 13.38 & 14.16 & 15.10 & 12.60 \\
\hline
\end{tabular}

Notes: The dependent variable is the long difference of the natural log of the probability-weighted patent count for a firm-product cluster between 2000 and a given year. Each column represents a different long difference, ranging from 2003 to 2011. The probability weights on the patent counts are generated by the Algorithmic Links with Probabilities approach that generates a concordance between IPC patent classes and HS codes. Offshoring is the long difference of the natural log of the value, in US dollars, of export stock from China by the same Taiwanese firms in the same product cluster, between 2000 and the same given year. The specifications are 2SLS specifications, where the instrument is a dummy variable set to one if the product cluster was affected by the 2001 policy change, and zero otherwise. These results are based on the subsample of product categories that were more focused on product innovation prior to the offshoring shock. 
Table 11: The Within-Category Impact of Logged Differenced Offshoring on the Nature of Patenting (Subsample of Categories Focused on Process Innovation Before Offshoring)

Table Shows Second Stage Regression Coefficients

Dependent Variable: Logged Long-Differenced Patents

\begin{tabular}{|c|c|c|c|c|c|c|c|c|c|}
\hline & $\begin{array}{c}(1) \\
2003-0 \\
\end{array}$ & $\begin{array}{c}(2) \\
2004-0 \\
\end{array}$ & $\begin{array}{c}3) \\
2005-0\end{array}$ & $\begin{array}{c}(4) \\
2006-0 \\
\end{array}$ & $\begin{array}{c}5) \\
2007-0 \\
\end{array}$ & $\begin{array}{c}(6) \\
2008-0 \\
\end{array}$ & $\begin{array}{c}7) \\
2009-0 \\
\end{array}$ & $\begin{array}{c}(8) \\
2010-0 \\
\end{array}$ & $\begin{array}{c}(9) \\
2011-0 \\
\end{array}$ \\
\hline \multirow{2}{*}{$\begin{array}{l}\text { Change in } \\
\text { Offshoring }\end{array}$} & 0.00856 & 0.00555 & -0.00130 & 0.000145 & 0.00493 & 0.00827 & $0.0318 * * *$ & $0.0209 * *$ & $0.0163^{*}$ \\
\hline & $(0.00667)$ & $(0.00601)$ & $(0.00638)$ & $(0.00666)$ & $(0.00661)$ & $(0.00808)$ & $(0.00975)$ & $(0.00953)$ & $(0.00958)$ \\
\hline Constant & $\begin{array}{l}0.00701 \\
(0.0169)\end{array}$ & $\begin{array}{c}0.0453 * * \\
(0.0198)\end{array}$ & $\begin{array}{c}0.0766 * * * \\
(0.0243)\end{array}$ & $\begin{array}{c}0.0961 * * * \\
(0.0276)\end{array}$ & $\begin{array}{c}0.0825 * * * \\
(0.0307)\end{array}$ & $\begin{array}{c}0.0876 * * \\
(0.0382)\end{array}$ & $\begin{array}{l}-0.0169 \\
(0.0455)\end{array}$ & $\begin{array}{c}0.0218 \\
(0.0499)\end{array}$ & $\begin{array}{c}0.0419 \\
(0.0518)\end{array}$ \\
\hline Observations & 1,664 & 1,664 & 1,664 & 1,664 & 1,664 & 1,664 & 1,664 & 1,664 & 1,664 \\
\hline First stage F & 39.78 & 57 & 46.03 & 52.38 & 54.45 & 54.80 & 55.75 & 50.20 & 42.28 \\
\hline
\end{tabular}

Notes: The dependent variable is the long difference of the natural $\log$ of the probability-weighted patent count for a firm-product cluster between 2000 and a given year. Each column represents a different long difference, ranging from 2003 to 2011. The probability weights on the patent counts are generated by the Algorithmic Links with Probabilities approach that generates a concordance between IPC patent classes and HS codes. Offshoring is the long difference of the natural $\log$ of the value, in US dollars, of export stock from China by the same Taiwanese firms in the same product cluster, between 2000 and the same given year. The specifications are 2SLS specifications, where the instrument is a dummy variable set to one if the product cluster was affected by the 2001 policy change, and zero otherwise. These results are based on the subsample of product categories that were more focused on product innovation prior to the offshoring shock. 
Table 12: The Second-Order, Cross-Category Impact of Logged Differenced Offshoring on Levels of Patenting

Table Shows Second Stage Regression Coefficients

Dependent Variable: Logged Long-Differenced Technologically Proximate Patent Counts, Weighted by Inverse of Distance

\begin{tabular}{|c|c|c|c|c|c|c|c|c|c|}
\hline & $\begin{array}{c}(1) \\
2003-0 \\
\end{array}$ & $\begin{array}{c}(2) \\
2004-0 \\
\end{array}$ & $\begin{array}{c}(3) \\
2005-0 \\
\end{array}$ & $\begin{array}{c}(4) \\
2006-0 \\
\end{array}$ & $\begin{array}{c}5) \\
2007-0 \\
\end{array}$ & $\begin{array}{c}(6) \\
2008-0 \\
\end{array}$ & $\begin{array}{c}(7) \\
2009-0 \\
\end{array}$ & $\begin{array}{c}(8) \\
2010-0 \\
\end{array}$ & $\begin{array}{c}(9) \\
2011-0 \\
\end{array}$ \\
\hline \multirow{2}{*}{$\begin{array}{l}\text { Change in } \\
\text { Offshoring }\end{array}$} & 0.000927 & $0.00153 * *$ & $0.00238^{* * * *}$ & $0.00285 * *$ & $0.00192 * *$ & $0.00213 * *$ & $0.00181 * *$ & $0.00188^{*}$ & $0.00201 *$ \\
\hline & $(0.000824)$ & $(0.000676)$ & $(0.000876)$ & $(0.00133)$ & $(0.000865)$ & $(0.000870)$ & $(0.000918)$ & $(0.00108)$ & $(0.00111)$ \\
\hline Constant & $\begin{array}{l}-0.00176 \\
(0.00175)\end{array}$ & $\begin{array}{c}-0.00355^{*} \\
(0.00188)\end{array}$ & $\begin{array}{c}-0.00788 * * \\
(0.00330)\end{array}$ & $\begin{array}{c}-0.0109 * * \\
(0.00552)\end{array}$ & $\begin{array}{c}-0.00830 * * \\
(0.00406)\end{array}$ & $\begin{array}{c}-0.0101 * * \\
(0.00452)\end{array}$ & $\begin{array}{c}-0.00839 * \\
(0.00476)\end{array}$ & $\begin{array}{l}-0.00978 \\
(0.00610)\end{array}$ & $\begin{array}{c}-0.0115^{*} \\
(0.00691)\end{array}$ \\
\hline Observations & 3,665 & 3,665 & 3,665 & 3,665 & 3,665 & 3,665 & 3,665 & 3,665 & 3,665 \\
\hline First stage $F$ & 21.48 & 30.35 & 26.95 & 29.48 & 40.87 & 42.23 & 41.88 & 40.02 & 33.15 \\
\hline
\end{tabular}

Notes: The dependent variable is the long-differenced count of technologically-proximate patents. These are not the patents of the categories that were offshored, but the patents of non-offshored but technologically proximate patents. Offshoring is the long difference of the logged value, in US dollars, of export stock from China by the same

Taiwanese firms in the same product cluster, between 2000 and the same given year. The specifications are 2SLS specifications, where the instrument is a dummy variable set to one if the product cluster was affected by the 2001 policy change, and zero otherwise. The regression tests the possibility of whether a firm - after offshoring some products - switches its innovative focus and resources to closely-related products, and it finds precisely what that hypothesis would predict: a positive coefficient on export value. 
Table 13: The Cross-Category Impact of Logged Differenced Offshoring on the Nature of Patenting (Product Innovation)

Table Shows Second Stage Regression Coefficients

Dependent Variable: Logged Long-Differenced Technologically-Proximate Product Patents, Weighted by Inverse of Technological Distance

\begin{tabular}{|c|c|c|c|c|c|c|c|c|c|}
\hline VARIABLES & $\begin{array}{c}(1) \\
2003-0 \\
\end{array}$ & $\begin{array}{c}(2) \\
2004-0 \\
\end{array}$ & $\begin{array}{c}3) \\
2005-0 \\
\end{array}$ & $\begin{array}{c}(4) \\
2006-0 \\
\end{array}$ & $\begin{array}{c}5) \\
2007-0 \\
\end{array}$ & $\begin{array}{c}(6) \\
2008-0 \\
\end{array}$ & $\begin{array}{c}(7) \\
2009-0 \\
\end{array}$ & $\begin{array}{c}(8) \\
2010-0 \\
\end{array}$ & $\begin{array}{c}(9) \\
2011-0\end{array}$ \\
\hline Change in & 0.000890 & $0.00149 * *$ & $0.00229 * * *$ & $0.00272 * *$ & $0.00176^{* *}$ & $0.00189 * *$ & $0.00165^{*}$ & $0.00185^{*}$ & $0.00184 *$ \\
\hline & $(0.000815)$ & $(0.000667)$ & $(0.000853)$ & $(0.00127)$ & $(0.000783)$ & $(0.000788)$ & $(0.000885)$ & $(0.00105)$ & $(0.00101)$ \\
\hline Constant & $\begin{array}{c}-0.00172 \\
(0.00174)\end{array}$ & $\begin{array}{c}-0.00361 * \\
(0.00186)\end{array}$ & $\begin{array}{c}-0.00773 * * \\
(0.00322)\end{array}$ & $\begin{array}{c}-0.0106 * * \\
(0.00531)\end{array}$ & $\begin{array}{c}-0.00778 * * \\
(0.00370)\end{array}$ & $\begin{array}{c}-0.00919 * * \\
(0.00409)\end{array}$ & $\begin{array}{c}-0.00796 * \\
(0.00462)\end{array}$ & $\begin{array}{c}-0.00998^{*} \\
(0.00593)\end{array}$ & $\begin{array}{c}-0.0109 * \\
(0.00628)\end{array}$ \\
\hline Observations & 3,665 & 3,665 & 3,665 & 3,665 & 3,665 & 3,665 & 3,665 & 3,665 & 3,665 \\
\hline First stage $F$ & 21.48 & 30.35 & 26.95 & 29.48 & 40.87 & 42.23 & 41.88 & 40.02 & 33.15 \\
\hline
\end{tabular}

Notes: The dependent variable is the long-differenced count of technologically-proximate product patents. These are not the product patents of the categories that were offshored, but the process patents of non-offshored but technologically proximate patents. Offshoring is the long difference of the logged value, in US dollars, of export stock from China by the same Taiwanese firms in the same product cluster, between 2000 and the same given year. The specifications are 2SLS specifications, where the instrument is a dummy variable set to one if the product cluster was affected by the 2001 policy change, and zero otherwise. 
Table 14: The Cross-Category Impact of Logged Differenced Offshoring on the Nature of Patenting (Process Innovation)

Table Shows Second Stage Regression Coefficients

Dependent Variable: Logged Long-Differenced Technologically-Proximate Process Patents, Weighted by Inverse of Technological Distance

\begin{tabular}{|c|c|c|c|c|c|c|c|c|c|}
\hline VARIABLES & $\begin{array}{c}(1) \\
2003-0 \\
\end{array}$ & $\begin{array}{c}(2) \\
2004-0 \\
\end{array}$ & $\begin{array}{c}(3) \\
2005-0 \\
\end{array}$ & $\begin{array}{c}(4) \\
2006-0 \\
\end{array}$ & $\begin{array}{c}(5) \\
2007-0 \\
\end{array}$ & $\begin{array}{c}(6) \\
2008-0 \\
\end{array}$ & $\begin{array}{c}(7) \\
2009-0 \\
\end{array}$ & $\begin{array}{c}(8) \\
2010-0 \\
\end{array}$ & $\begin{array}{c}(9) \\
2011-0 \\
\end{array}$ \\
\hline $\begin{array}{l}\text { Change in } \\
\text { Offshoring }\end{array}$ & $\begin{array}{c}9.07 \mathrm{e}-05 \\
(6.73 \mathrm{e}-05)\end{array}$ & $\begin{array}{c}7.12 \mathrm{e}-05 \\
(5.41 \mathrm{e}-05)\end{array}$ & $\begin{array}{l}8.61 \mathrm{e}-05 \\
(8.59 \mathrm{e}-05)\end{array}$ & $\begin{array}{c}6.81 \mathrm{e}-05 \\
(6.81 \mathrm{e}-05)\end{array}$ & $\begin{array}{c}3.26 \mathrm{e}-05 \\
(5.69 \mathrm{e}-05)\end{array}$ & $\begin{array}{c}0.000164 \\
(0.000144)\end{array}$ & $\begin{array}{c}4.72 \mathrm{e}-05 \\
(5.56 \mathrm{e}-05)\end{array}$ & $\begin{array}{l}-1.34 \mathrm{e}-05 \\
(3.42 \mathrm{e}-05)\end{array}$ & $\begin{array}{c}0.000129 \\
(8.84 \mathrm{e}-05)\end{array}$ \\
\hline Constant & $\begin{array}{c}-0.000161 \\
(0.000135)\end{array}$ & $\begin{array}{c}-0.000118 \\
(0.000138)\end{array}$ & $\begin{array}{c}-0.000266 \\
(0.000304)\end{array}$ & $\begin{array}{c}-0.000213 \\
(0.000273)\end{array}$ & $\begin{array}{c}-9.84 \mathrm{e}-05 \\
(0.000272)\end{array}$ & $\begin{array}{c}-0.000806 \\
(0.000775)\end{array}$ & $\begin{array}{l}-0.000169 \\
(0.000317)\end{array}$ & $\begin{array}{c}0.000184 \\
(0.000213)\end{array}$ & $\begin{array}{c}-0.000744 \\
(0.000580)\end{array}$ \\
\hline $\begin{array}{l}\text { Observations } \\
\text { First stage F }\end{array}$ & $\begin{array}{l}3,665 \\
21.48\end{array}$ & $\begin{array}{l}3,665 \\
30.35\end{array}$ & $\begin{array}{l}3,665 \\
26.95\end{array}$ & $\begin{array}{l}3,665 \\
29.48\end{array}$ & $\begin{array}{l}3,665 \\
40.87\end{array}$ & $\begin{array}{l}3,665 \\
42.23\end{array}$ & $\begin{array}{l}3,665 \\
41.88\end{array}$ & $\begin{array}{l}3,665 \\
40.02\end{array}$ & $\begin{array}{l}3,665 \\
33.15\end{array}$ \\
\hline
\end{tabular}

Notes: The dependent variable is the long-differenced count of technologically-proximate process patents. These are not the process patents of the categories that were offshored, but the process patents of non-offshored but technologically proximate patents. Offshoring is the long difference of the logged value, in US dollars, of export stock from China by the same Taiwanese firms in the same product cluster, between 2000 and the same given year. The specifications are 2SLS specifications, where the instrument is a dummy variable set to one if the product cluster was affected by the 2001 policy change, and zero otherwise. 


\section{Appendix}

\section{Appendix A1. Distribution of Key Variables Pre- and Post-Aggregation}

As described in section 4e, we aggregated 669 product categories up to 16 clusters for use in analysis. Extensive aggregation raises the concern that our regression analysis results are an artifact of the particular aggregation scheme we used. The following figures address this concern by plot the distribution of patenting and export values for affected and unaffected categories and for the aggregated and unaggregated data. We use violin plots-which are a hybrid of a box plot and a kernel density plot - to illustrate the distributions. Wider (narrower) sections of the plot represent a higher (lower) probability that members of the population will take on the given value. The plots on the left show the distributions of the raw data over time, while the plots on the right show the distributions of the aggregated data over time.
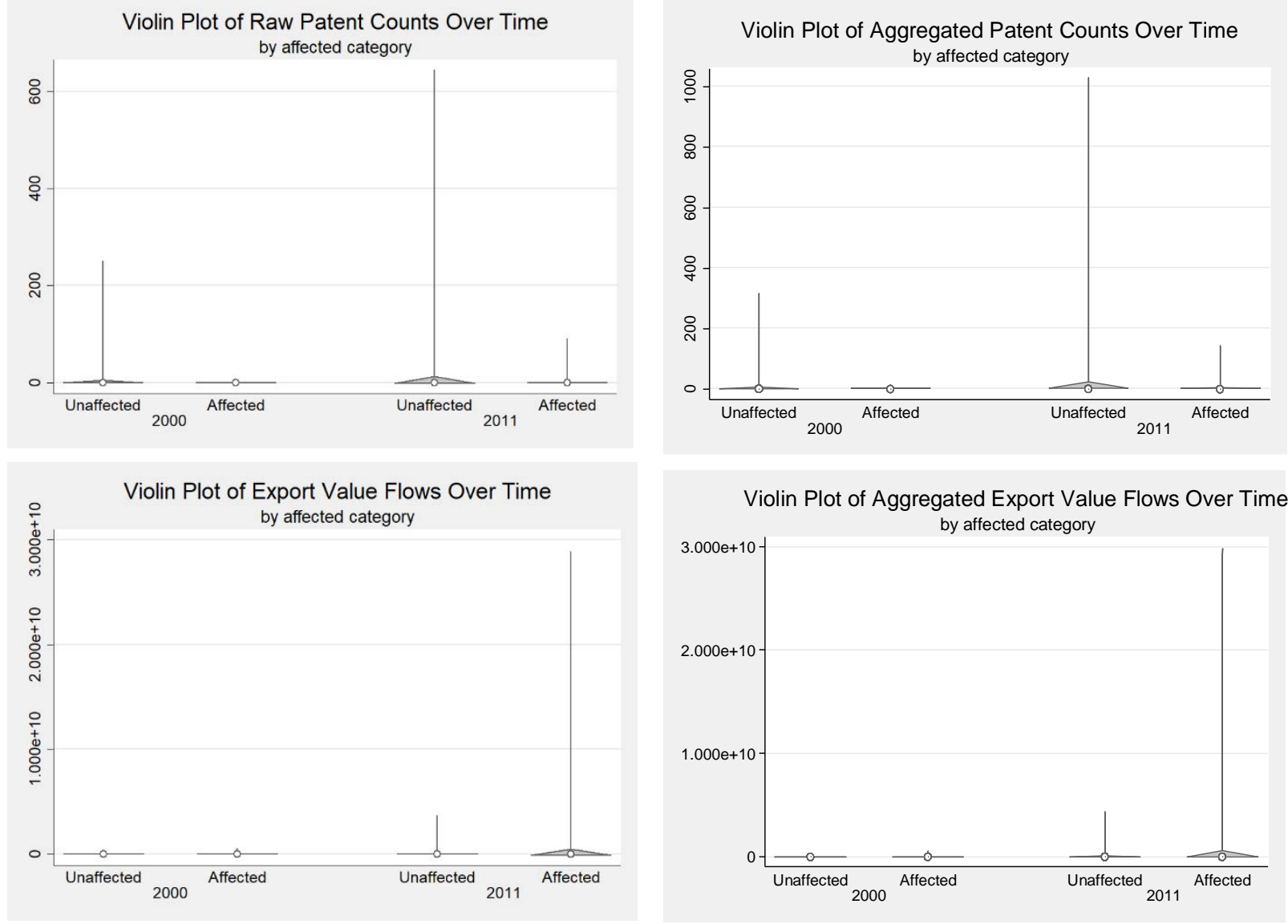

The figures tell the same basic story; there is a significant increase in offshoring in the affected product categories between 2000 and 2011 in response to the policy change, but very little increase in patenting in those categories. In contrast, patenting increases dramatically for the product categories that could not be offshored. This story is apparent in the distributions for both the aggregated and raw data. 


\section{Appendix A2. US Firm Patenting in Clusters Affected vs Unaffected by Taiwan Policy Shock}

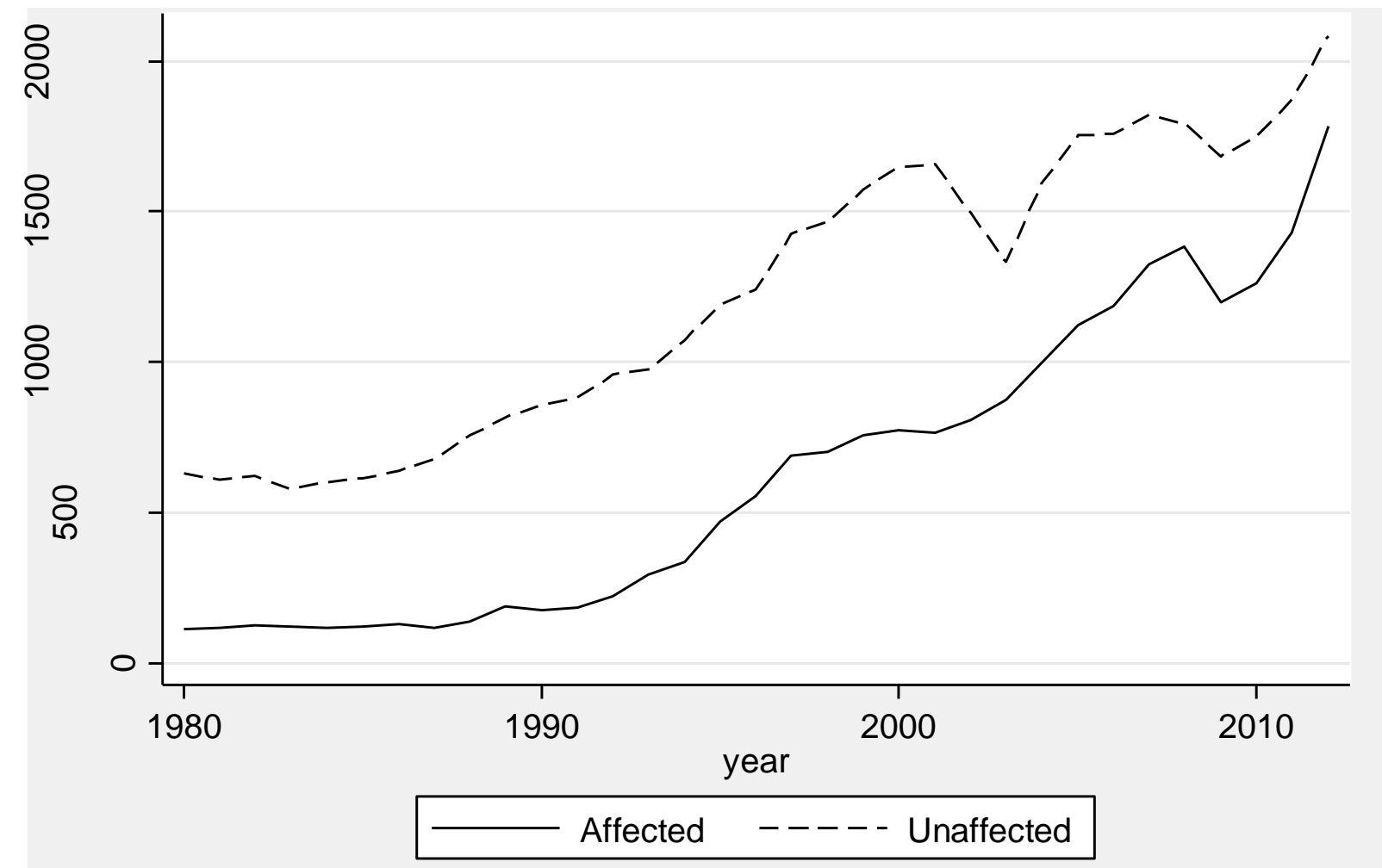

Shifts in patenting could reflect broader trends in the underlying technological opportunities facing different technology clusters. This figure addresses that concern by plotting changes over time in patenting by U.S. firms in the patent classes associated with the product-technology clusters affected and not affected by the Taiwanese policy change. The gap in patent numbers taken out by U.S. firms narrows significantly across these groups over time. If we were worried about global technology trends confounding our results, we would have expected to observe a widening gap in the years 2001-2011. If anything, the broader technology trends reflected in patenting by U.S. firms appear to be biasing us against the results that we find for Taiwanese firms. 


\section{Appendix A3: Robustness Checks}

Table A3.1: 2SLS Regressions, Effect of Logged Differenced Export Value on Logged Differenced Patent Counts, with global technology pre-trends control

\begin{tabular}{|c|c|c|c|c|c|c|c|c|c|}
\hline VARIABLES & $\begin{array}{c}(1) \\
2003-0\end{array}$ & $\begin{array}{c}(2) \\
2004-0\end{array}$ & $\begin{array}{c}(3) \\
2005-0\end{array}$ & $\begin{array}{c}(4) \\
2006-0\end{array}$ & $\begin{array}{c}(5) \\
2007-0\end{array}$ & $\begin{array}{c}(6) \\
2008-0\end{array}$ & $\begin{array}{c}(7) \\
2009-0\end{array}$ & $\begin{array}{c}(8) \\
2010-0\end{array}$ & $\begin{array}{c}(9) \\
2011-0\end{array}$ \\
\hline Offshoring & $\begin{array}{l}-0.0283 \\
(0.0285)\end{array}$ & $\begin{array}{l}-0.0491 \\
(0.0306)\end{array}$ & $\begin{array}{c}-0.101 * * \\
(0.0426)\end{array}$ & $\begin{array}{c}-0.137 * * \\
(0.0570)\end{array}$ & $\begin{array}{c}-0.0966 * * * \\
(0.0284)\end{array}$ & $\begin{array}{c}-0.109 * * * \\
(0.0296)\end{array}$ & $\begin{array}{c}-0.0867 * * * \\
(0.0232)\end{array}$ & $\begin{array}{c}-0.0898 * * * \\
(0.0230)\end{array}$ & $\begin{array}{c}-0.0988 * * * \\
(0.0252)\end{array}$ \\
\hline $\begin{array}{l}1995-1999 \text { global } \\
\text { pretrend }\end{array}$ & $\begin{array}{c}0.483 \\
(0.298)\end{array}$ & $\begin{array}{l}0.876 * * \\
(0.419)\end{array}$ & $\begin{array}{c}1.573 * * * \\
(0.591)\end{array}$ & $\begin{array}{c}2.243 * * * \\
(0.829)\end{array}$ & $\begin{array}{c}1.756 * * * \\
(0.436)\end{array}$ & $\begin{array}{c}2.023 * * * \\
(0.481)\end{array}$ & $\begin{array}{c}2.158 * * * \\
(0.405)\end{array}$ & $\begin{array}{c}1.816 * * * \\
(0.375)\end{array}$ & $\begin{array}{c}1.518 * * * \\
(0.369)\end{array}$ \\
\hline Constant & $\begin{array}{c}0.0576 \\
(0.0449)\end{array}$ & $\begin{array}{l}0.147 * * \\
(0.0602)\end{array}$ & $\begin{array}{l}0.341 * * * \\
(0.115)\end{array}$ & $\begin{array}{c}0.530 * * * \\
(0.179)\end{array}$ & $\begin{array}{c}0.477 * * * \\
(0.117)\end{array}$ & $\begin{array}{c}0.582 * * * \\
(0.136)\end{array}$ & $\begin{array}{c}0.487 * * * \\
(0.116)\end{array}$ & $\begin{array}{c}0.555^{* * * *} \\
(0.127)\end{array}$ & $\begin{array}{c}0.665^{* * * *} \\
(0.151)\end{array}$ \\
\hline $\begin{array}{l}\text { Observations } \\
\text { First stage F }\end{array}$ & $\begin{array}{l}3,278 \\
5.108 \\
\end{array}$ & $\begin{array}{l}3,278 \\
7.014 \\
\end{array}$ & $\begin{array}{l}3,278 \\
7.632 \\
\end{array}$ & $\begin{array}{l}3,278 \\
7.668 \\
\end{array}$ & $\begin{array}{l}3,278 \\
17.21 \\
\end{array}$ & $\begin{array}{l}3,278 \\
18.78 \\
\end{array}$ & $\begin{array}{l}3,278 \\
22.19 \\
\end{array}$ & $\begin{array}{l}3,278 \\
24.50 \\
\end{array}$ & $\begin{array}{l}3,278 \\
22.77 \\
\end{array}$ \\
\hline
\end{tabular}

Table A3.2: 2SLS Regressions, Effect of Logged Differenced Export Value on Logged Differenced Patent Counts, with Taiwanese technology pre-trends control

\begin{tabular}{|c|c|c|c|c|c|c|c|c|c|}
\hline VARIABLES & $\begin{array}{c}(1) \\
2003-0 \\
\end{array}$ & $\begin{array}{c}(2) \\
2004-0 \\
\end{array}$ & $\begin{array}{c}(3) \\
2005-0\end{array}$ & $\begin{array}{c}(4) \\
2006-0 \\
\end{array}$ & $\begin{array}{c}(5) \\
2007-0\end{array}$ & $\begin{array}{c}(6) \\
2008-0 \\
\end{array}$ & $\begin{array}{c}(7) \\
2009-0 \\
\end{array}$ & $\begin{array}{c}(8) \\
2010-0 \\
\end{array}$ & $\begin{array}{c}(9) \\
2011-0 \\
\end{array}$ \\
\hline Offshoring & $\begin{array}{l}-0.00920 \\
(0.0231)\end{array}$ & $\begin{array}{l}-0.0200 \\
(0.0185)\end{array}$ & $\begin{array}{c}-0.0637 * * \\
(0.0273)\end{array}$ & $\begin{array}{c}-0.0784 * * \\
(0.0316)\end{array}$ & $\begin{array}{c}-0.0548 * * * \\
(0.0186)\end{array}$ & $\begin{array}{c}-0.0509 * * * \\
(0.0180)\end{array}$ & $\begin{array}{l}-0.0140 \\
(0.0149)\end{array}$ & $\begin{array}{l}-0.0294 * \\
(0.0160)\end{array}$ & $\begin{array}{c}-0.0446 * * \\
(0.0196)\end{array}$ \\
\hline $\begin{array}{l}\text { 1995-1999 Taiwan } \\
\text { pretrend }\end{array}$ & $\begin{array}{c}-0.0105 \\
(0.00669)\end{array}$ & $\begin{array}{l}-0.0163 * * \\
(0.00697)\end{array}$ & $\begin{array}{c}-0.0401 * * * \\
(0.0108)\end{array}$ & $\begin{array}{c}-0.0503 * * * \\
(0.0129)\end{array}$ & $\begin{array}{c}-0.0450 * * * \\
(0.00798)\end{array}$ & $\begin{array}{c}-0.0396 * * * \\
(0.00761)\end{array}$ & $\begin{array}{c}-0.0281 * * * \\
(0.00644)\end{array}$ & $\begin{array}{c}-0.0288 * * * \\
(0.00648)\end{array}$ & $\begin{array}{c}-0.0284 * * * \\
(0.00667)\end{array}$ \\
\hline Constant & $\begin{array}{c}0.0724 \\
(0.0634)\end{array}$ & $\begin{array}{l}0.159 * * \\
(0.0669)\end{array}$ & $\begin{array}{l}0.389 * * * \\
(0.114)\end{array}$ & $\begin{array}{l}0.534 * * * \\
(0.148)\end{array}$ & $\begin{array}{l}0.480^{* * * *} \\
(0.102)\end{array}$ & $\begin{array}{l}0.497 * * * \\
(0.106)\end{array}$ & $\begin{array}{l}0.299 * * * \\
(0.0922)\end{array}$ & $\begin{array}{l}0.383^{* * * *} \\
(0.105)\end{array}$ & $\begin{array}{c}0.484 * * * \\
(0.128)\end{array}$ \\
\hline $\begin{array}{l}\text { Observations } \\
\text { First stage F }\end{array}$ & $\begin{array}{l}3,562 \\
7.011\end{array}$ & $\begin{array}{l}3,562 \\
11.16\end{array}$ & $\begin{array}{l}3,562 \\
9.956\end{array}$ & $\begin{array}{l}3,562 \\
10.53\end{array}$ & $\begin{array}{l}3,562 \\
21.78\end{array}$ & $\begin{array}{l}3,562 \\
23.18\end{array}$ & $\begin{array}{l}3,562 \\
23.43\end{array}$ & $\begin{array}{l}3,562 \\
22.73\end{array}$ & $\begin{array}{l}3,562 \\
18.54\end{array}$ \\
\hline
\end{tabular}

Table A3.3: 2SLS Regressions, Effect of Logged Differenced Export Value on Logged Differenced Patent Counts, 16 Euclidean Clusters

\begin{tabular}{|c|c|c|c|c|c|c|c|c|c|}
\hline VARIABLES & $\begin{array}{c}(1) \\
2003-0 \\
\end{array}$ & $\begin{array}{c}(2) \\
2004-0 \\
\end{array}$ & $\begin{array}{c}(3) \\
2005-0 \\
\end{array}$ & $\begin{array}{c}(4) \\
2006-0 \\
\end{array}$ & $\begin{array}{c}(5) \\
2007-0 \\
\end{array}$ & $\begin{array}{c}(6) \\
2008-0 \\
\end{array}$ & $\begin{array}{c}(7) \\
2009-0 \\
\end{array}$ & $\begin{array}{c}(8) \\
2010-0 \\
\end{array}$ & $\begin{array}{c}(9) \\
2011-0 \\
\end{array}$ \\
\hline Offshoring & $\begin{array}{c}0.00823 \\
(0.0160)\end{array}$ & $\begin{array}{r}0.000987 \\
(0.0119)\end{array}$ & $\begin{array}{c}-0.0270 * * \\
(0.0128)\end{array}$ & $\begin{array}{c}-0.0285^{* *} * \\
(0.0134)\end{array}$ & $\begin{array}{c}-0.0246^{*} \\
(0.0130)\end{array}$ & $\begin{array}{l}-0.0221 \\
(0.0141)\end{array}$ & $\begin{array}{l}0.00894 \\
(0.0135)\end{array}$ & $\begin{array}{c}-0.0134 \\
(0.0140)\end{array}$ & $\begin{array}{l}-0.0260 \\
(0.0172)\end{array}$ \\
\hline Constant & $\begin{array}{c}0.0203 \\
(0.0324)\end{array}$ & $\begin{array}{c}0.0693 * * \\
(0.0319)\end{array}$ & $\begin{array}{c}0.179 * * * \\
(0.0438)\end{array}$ & $\begin{array}{c}0.230 * * * \\
(0.0515)\end{array}$ & $\begin{array}{c}0.244 * * * \\
(0.0581)\end{array}$ & $\begin{array}{c}0.258 * * * \\
(0.0663)\end{array}$ & $\begin{array}{c}0.119 * \\
(0.0637)\end{array}$ & $\begin{array}{c}0.218 * * * \\
(0.0751)\end{array}$ & $\begin{array}{r}0.289 * * * \\
(0.0931)\end{array}$ \\
\hline $\begin{array}{l}\text { Observations } \\
\text { First stage F }\end{array}$ & $\begin{array}{l}5,263 \\
14.22\end{array}$ & $\begin{array}{l}5,263 \\
25.93\end{array}$ & $\begin{array}{l}5,263 \\
25.39\end{array}$ & $\begin{array}{l}5,263 \\
27.73\end{array}$ & $\begin{array}{l}5,263 \\
28.66\end{array}$ & $\begin{array}{l}5,263 \\
29.50\end{array}$ & $\begin{array}{l}5,263 \\
28.38\end{array}$ & $\begin{array}{l}5,263 \\
24.35\end{array}$ & $\begin{array}{l}5,263 \\
18.28\end{array}$ \\
\hline
\end{tabular}

Firm-clustered standard errors in parentheses

$* * * \mathrm{p}<0.01, * * \mathrm{p}<0.05, * \mathrm{p}<0.1$ 
Table A3.4: 2SLS Regressions, Effect of Logged Differenced Export Value on Logged Differenced Patent Counts, 16 Canberra Clusters

\begin{tabular}{|c|c|c|c|c|c|c|c|c|c|}
\hline VARIABLES & $\begin{array}{c}(1) \\
2003-0 \\
\end{array}$ & $\begin{array}{c}(2) \\
2004-0 \\
\end{array}$ & $\begin{array}{c}(3) \\
2005-0\end{array}$ & $\begin{array}{c}(4) \\
2006-0 \\
\end{array}$ & $\begin{array}{c}(5) \\
2007-0 \\
\end{array}$ & $\begin{array}{c}(6) \\
2008-0 \\
\end{array}$ & $\begin{array}{c}(7) \\
2009-0 \\
\end{array}$ & $\begin{array}{c}(8) \\
2010-0 \\
\end{array}$ & $\begin{array}{c}(9) \\
2011-0 \\
\end{array}$ \\
\hline Offshoring & $\begin{array}{c}0.0114 \\
(0.0164)\end{array}$ & $\begin{array}{l}0.00464 \\
(0.0116)\end{array}$ & $\begin{array}{c}-0.0216^{*} \\
(0.0111)\end{array}$ & $\begin{array}{c}-0.0248 * * \\
(0.0112)\end{array}$ & $\begin{array}{l}-0.0181 * \\
(0.00934)\end{array}$ & $\begin{array}{c}-0.0232 * * \\
(0.0103)\end{array}$ & $\begin{array}{l}-0.00275 \\
(0.00906)\end{array}$ & $\begin{array}{c}-0.0170 * \\
(0.00988)\end{array}$ & $\begin{array}{c}-0.0211^{* *} \\
(0.0103)\end{array}$ \\
\hline Constant & $\begin{array}{c}0.0132 \\
(0.0339)\end{array}$ & $\begin{array}{l}0.0580 * \\
(0.0322)\end{array}$ & $\begin{array}{c}0.166^{* * * *} \\
(0.0391)\end{array}$ & $\begin{array}{c}0.222 * * * \\
(0.0451)\end{array}$ & $\begin{array}{c}0.219 * * * \\
(0.0440)\end{array}$ & $\begin{array}{c}0.268 * * * \\
(0.0518)\end{array}$ & $\begin{array}{c}0.176^{* * * *} \\
(0.0477)\end{array}$ & $\begin{array}{c}0.241 * * * \\
(0.0582)\end{array}$ & $\begin{array}{c}0.268 * * * \\
(0.0601)\end{array}$ \\
\hline $\begin{array}{l}\text { Observations } \\
\text { First stage F }\end{array}$ & $\begin{array}{l}4,861 \\
16.16\end{array}$ & $\begin{array}{l}4,861 \\
30.36\end{array}$ & $\begin{array}{l}4,861 \\
33.64\end{array}$ & $\begin{array}{l}4,861 \\
42.92\end{array}$ & $\begin{array}{l}4,861 \\
51.04\end{array}$ & $\begin{array}{l}4,861 \\
55.49\end{array}$ & $\begin{array}{l}4,861 \\
58.90\end{array}$ & $\begin{array}{l}4,861 \\
52.46\end{array}$ & $\begin{array}{l}4,861 \\
47.70\end{array}$ \\
\hline
\end{tabular}

Table A3.5: 2SLS Regressions, Effect of Logged Differenced Export Value on Logged Differenced Patent Counts, 18 Gower Clusters

\begin{tabular}{|c|c|c|c|c|c|c|c|c|c|}
\hline VARIABLES & $\begin{array}{c}(1) \\
2003-0 \\
\end{array}$ & $\begin{array}{c}(2) \\
2004-0 \\
\end{array}$ & $\begin{array}{c}3) \\
2005-0 \\
\end{array}$ & $\begin{array}{c}(4) \\
2006-0 \\
\end{array}$ & $\begin{array}{c}5) \\
2007-0 \\
\end{array}$ & $\begin{array}{c}6) \\
2008-0 \\
\end{array}$ & $\begin{array}{c}(7) \\
2009-0 \\
\end{array}$ & $\begin{array}{c}(8) \\
2010-0 \\
\end{array}$ & $\begin{array}{c}(9) \\
2011-0 \\
\end{array}$ \\
\hline Offshoring & $\begin{array}{l}0.00103 \\
(0.0100)\end{array}$ & $\begin{array}{c}-0.00542 \\
(0.00830)\end{array}$ & $\begin{array}{l}-0.0228 * * \\
(0.00936)\end{array}$ & $\begin{array}{c}-0.0287 * * * \\
(0.0106)\end{array}$ & $\begin{array}{l}-0.0204 * * \\
(0.00848)\end{array}$ & $\begin{array}{c}-0.0210^{* * *} \\
(0.00884)\end{array}$ & $\begin{array}{c}3.70 \mathrm{e}-05 \\
(0.00823)\end{array}$ & $\begin{array}{c}-0.0108 \\
(0.00875)\end{array}$ & $\begin{array}{r}-0.0191 * * \\
(0.00958)\end{array}$ \\
\hline Constant & $\begin{array}{c}0.0344 \\
(0.0273)\end{array}$ & $\begin{array}{c}0.0913 * * * \\
(0.0303)\end{array}$ & $\begin{array}{c}0.183 * * * \\
(0.0393)\end{array}$ & $\begin{array}{c}0.255^{* * * *} \\
(0.0489)\end{array}$ & $\begin{array}{c}0.244 * * * \\
(0.0453)\end{array}$ & $\begin{array}{c}0.274 * * * \\
(0.0510)\end{array}$ & $\begin{array}{c}0.171 * * * \\
(0.0486)\end{array}$ & $\begin{array}{c}0.225 * * * \\
(0.0572)\end{array}$ & $\begin{array}{c}0.279 * * * \\
(0.0628)\end{array}$ \\
\hline $\begin{array}{l}\text { Observations } \\
\text { R-squared } \\
\text { First stage F }\end{array}$ & $\begin{array}{l}3,856 \\
0.002 \\
25.12\end{array}$ & $\begin{array}{c}3,856 \\
-0.016 \\
35.09\end{array}$ & $\begin{array}{c}3,856 \\
-0.138 \\
33.32 \\
\end{array}$ & $\begin{array}{r}3,856 \\
-0.182 \\
35.24\end{array}$ & $\begin{array}{c}3,856 \\
-0.118 \\
48.71 \\
\end{array}$ & $\begin{array}{c}3,856 \\
-0.093 \\
51.82\end{array}$ & $\begin{array}{l}3,856 \\
0.000 \\
52.01\end{array}$ & $\begin{array}{r}3,856 \\
-0.032 \\
49.80\end{array}$ & $\begin{array}{r}3,856 \\
-0.073 \\
42.14 \\
\end{array}$ \\
\hline
\end{tabular}

Firm cluster-robust standard errors in parentheses

$$
* * * \mathrm{p}<0.01, * * \mathrm{p}<0.05, * \mathrm{p}<0.1
$$

Table A3.6: 2SLS Regressions, Effect of Logged Differenced Export Value on Logged Differenced Patent Counts, excluding Foxconn

\begin{tabular}{|c|c|c|c|c|c|c|c|c|c|}
\hline VARIABLES & $\begin{array}{c}(1) \\
2003-0 \\
\end{array}$ & $\begin{array}{c}(2) \\
2004-0 \\
\end{array}$ & $\begin{array}{c}(3) \\
2005-0 \\
\end{array}$ & $\begin{array}{c}(4) \\
2006-0 \\
\end{array}$ & $\begin{array}{c}5) \\
2007-0 \\
\end{array}$ & $\begin{array}{c}(6) \\
2008-0 \\
\end{array}$ & $\begin{array}{c}(7) \\
2009-0 \\
\end{array}$ & $\begin{array}{c}(8) \\
2010-0 \\
\end{array}$ & $\begin{array}{c}(9) \\
2011-0 \\
\end{array}$ \\
\hline Offshoring & $\begin{array}{c}0.000531 \\
(0.0107)\end{array}$ & $\begin{array}{c}-0.00711 \\
(0.00910)\end{array}$ & $\begin{array}{c}-0.0260 * * \\
(0.0104)\end{array}$ & $\begin{array}{c}-0.0330 * * * \\
(0.0117)\end{array}$ & $\begin{array}{l}-0.0236 * * \\
(0.00922)\end{array}$ & $\begin{array}{c}-0.0258 * * * \\
(0.00978)\end{array}$ & $\begin{array}{l}-0.00370 \\
(0.00891)\end{array}$ & $\begin{array}{c}-0.0133 \\
(0.00934)\end{array}$ & $\begin{array}{c}-0.0232 * * \\
(0.0104)\end{array}$ \\
\hline Constant & $\begin{array}{c}0.0365 \\
(0.0288)\end{array}$ & $\begin{array}{c}0.0938 * * * \\
(0.0325)\end{array}$ & $\begin{array}{c}0.194 * * * \\
(0.0428)\end{array}$ & $\begin{array}{c}0.268 * * * \\
(0.0530)\end{array}$ & $\begin{array}{c}0.257 * * * \\
(0.0483)\end{array}$ & $\begin{array}{c}0.297 * * * \\
(0.0558)\end{array}$ & $\begin{array}{c}0.187 * * * \\
(0.0529)\end{array}$ & $\begin{array}{c}0.234 * * * \\
(0.0599)\end{array}$ & $\begin{array}{c}0.301 * * * \\
(0.0682)\end{array}$ \\
\hline Observations & 3,647 & 3,647 & 3,647 & 3,647 & 3,647 & 3,647 & 3,647 & 3,647 & 3,647 \\
\hline First stage $\mathrm{F}$ & 22.59 & 31.92 & 29.40 & 32.30 & 44.23 & 45.93 & 45.89 & 44.28 & 37.17 \\
\hline
\end{tabular}


Table A3.7: 2SLS Regressions, Effect of IHS Differenced Export Value on IHS Differenced Patent Counts

\begin{tabular}{|c|c|c|c|c|c|c|c|c|c|}
\hline VARIABLES & $\begin{array}{c}(1) \\
2003-0 \\
\end{array}$ & $\begin{array}{c}(2) \\
2004-0 \\
\end{array}$ & $\begin{array}{c}3) \\
2005-0 \\
\end{array}$ & $\begin{array}{c}(4) \\
2006-0 \\
\end{array}$ & $\begin{array}{c}5) \\
2007-0 \\
\end{array}$ & $\begin{array}{c}(6) \\
2008-0 \\
\end{array}$ & $\begin{array}{c}7) \\
2009-0 \\
\end{array}$ & $\begin{array}{c}(8) \\
2010-0 \\
\end{array}$ & $\begin{array}{c}(9) \\
2011-0 \\
\end{array}$ \\
\hline IHS(offshoring) & $\begin{array}{l}0.00221 \\
(0.0131)\end{array}$ & $\begin{array}{r}-0.00781 \\
(0.0110)\end{array}$ & $\begin{array}{c}-0.0299 * * \\
(0.0125)\end{array}$ & $\begin{array}{c}-0.0378 * * * \\
(0.0141)\end{array}$ & $\begin{array}{c}-0.0280 * * \\
(0.0112)\end{array}$ & $\begin{array}{c}-0.0299 * * \\
(0.0118)\end{array}$ & $\begin{array}{r}-0.00385 \\
(0.0108)\end{array}$ & $\begin{array}{c}-0.0164 \\
(0.0114)\end{array}$ & $\begin{array}{c}-0.0277 * * \\
(0.0127)\end{array}$ \\
\hline Constant & $\begin{array}{c}0.0402 \\
(0.0367)\end{array}$ & $\begin{array}{c}0.119 * * * \\
(0.0412)\end{array}$ & $\begin{array}{c}0.241 * * * \\
(0.0537)\end{array}$ & $\begin{array}{c}0.337 * * * \\
(0.0669)\end{array}$ & $\begin{array}{c}0.327 * * * \\
(0.0620)\end{array}$ & $\begin{array}{c}0.374 * * * \\
(0.0709)\end{array}$ & $\begin{array}{c}0.239 * * * \\
(0.0679)\end{array}$ & $\begin{array}{c}0.306^{* * * *} \\
(0.0778)\end{array}$ & $\begin{array}{c}0.385 * * * \\
(0.0876)\end{array}$ \\
\hline $\begin{array}{l}\text { Observations } \\
\text { First stage F }\end{array}$ & $\begin{array}{l}3,665 \\
22,45\end{array}$ & $\begin{array}{l}3,665 \\
31,87\end{array}$ & $\begin{array}{l}3,665 \\
28,97\end{array}$ & $\begin{array}{l}3,665 \\
31,65\end{array}$ & $\begin{array}{l}3,665 \\
43,41\end{array}$ & $\begin{array}{l}3,665 \\
44,97\end{array}$ & $\begin{array}{l}3,665 \\
44,81\end{array}$ & $\begin{array}{l}3,665 \\
43,06\end{array}$ & $\begin{array}{l}3,665 \\
35,97\end{array}$ \\
\hline
\end{tabular}

Firm-clustered standard errors in parentheses

${ }^{*} p<0.10,{ }^{* *} p<0.05,{ }^{* * *} p<0.01$ 


\section{Appendix A4. 122 Newly Permitted Product Categories}

\begin{tabular}{|c|c|c|c|}
\hline Category in Chinese & Category in English & CCC Code & $\begin{array}{c}\text { HS } \\
\text { Code }\end{array}$ \\
\hline $\begin{array}{l}\text { 光纖分散數據介面、同步光纖網路系統、整體服務數位網 } \\
\text { 路設備及其相關IC }\end{array}$ & $\begin{array}{l}\text { Fiber distributed data interface (FDDI), } \\
\text { Synchronous Optical Networking (SONET), } \\
\text { ISDN equipment and IC related products }\end{array}$ & 95421090 & 8517 \\
\hline 熱感應印字頭 & Thermal printhead (printer component) & 85179092108 & 851790 \\
\hline $\begin{array}{l}\text { 行動電話、數位行動電話、GSM 行動電話機、泛歐無線電 } \\
\text { 話 }(\text { DECT)、展頻數位無線電話、第二代數位無線CT2 } 2 \text { 基台 } \\
\text { 及手機、無線通信系統、數位式無線交換機與電話機、網 } \\
\text { 際網路電腦通訊器及國際海事衛星通信 } \mathrm{M} / \mathrm{B} \text { 型移動系統 }\end{array}$ & $\begin{array}{l}\text { all types of mobile phones, wireless } \\
\text { communication system, digital wireless } \\
\text { switches, satellite communications systems }\end{array}$ & 85252010102 & 852520 \\
\hline 電動空氣過濾器及電動空氣清潔器 & Filtering or purifying machinery for gase & 84213910 & 842139 \\
\hline 過濾芯子 ( 供立即使用者 ) & Cartridges for filter/purifying machines & 84219910 & 842199 \\
\hline 郵資機 & Postage machine & 84709010 & 847090 \\
\hline 其他第 8470 節所屬之機器 & Other 8470 machines & 84709090 & 847090 \\
\hline 高級CAD/CAM系統 & Advanced CAD/CAM system & 84710000 & 847110 \\
\hline 類比或混合自動資料處理機 & $\begin{array}{l}\text { Analog or hybrid automatic data processing } \\
\text { machine }\end{array}$ & 84711000 & 847110 \\
\hline $\begin{array}{l}\text { 攜帶式數位自動資料處理機, 其重量不超過 } 10 \text { 公斤並至 } \\
\text { 少包含有一中央處理單元，一鍵盤及一顯示器者 }\end{array}$ & $\begin{array}{l}\text { Portable automatic data-processing machines, } \\
\text { weighing not more than } 10 \mathrm{~kg} \text {, consisting of at } \\
\text { least a central processing unit, a keyboard and } \\
\text { a display }\end{array}$ & 84713000 & 847130 \\
\hline $\begin{array}{l}\text { 攜帶式數位自動資料處理機, 其重量不超過 } 10 \text { 公斤並至 } \\
\text { 少包含有一中央處理單元, 一鍵盤及一顯示器者(高級工作 } \\
\text { 站及相關RISC CHIPS、多處理機系統、醫療光卡、光卡閱 } \\
\text { 讀機個人電腦介面卡及光卡醫療記錄寫作系統、多媒體電 } \\
\text { 腦系統-硬體、軟體及應用系統、後置服務器、高性能跨越 } \\
\text { 網路之控制器) }\end{array}$ & $\begin{array}{l}\text { Portable automatic data-processing machines, } \\
\text { weighing not more than } 10 \mathrm{~kg} \text {, consisting of at } \\
\text { least a central processing unit, a keyboard and } \\
\text { a display (for work processing stations and } \\
\text { related to: RISC CHIPS, multiprocessor } \\
\text { systems, medical optical cards, interface card, } \\
\text { medical records system, multimedia systems - } \\
\text { hardware, software and applications, back } \\
\text { servers, high-performance networks and } \\
\text { controllers) }\end{array}$ & 84713000 & 847130 \\
\hline $\begin{array}{l}\text { 其他數位式自動資料處理機同一機殼內至少包含有一中央 } \\
\text { 處理單元及一輸入、輸出單元，不論是否組合者 }\end{array}$ & $\begin{array}{l}\text { Other digital automatic data processing } \\
\text { machines comprising at least a central } \\
\text { processing unit and an input and output unit }\end{array}$ & 84714100 & 847199 \\
\hline $\begin{array}{l}\text { 其他數位式自動資料處理機同一機殼內至少包含有一中央 } \\
\text { 處理單元及一輸入、輸出單元, 不論是否組合者(高級工作 } \\
\text { 站及相關RICS CHIPS、多處理機系統、醫療光卡、光卡閱 } \\
\text { 讀機個人電腦介面卡及光卡醫療記錄寫作系統、多媒體電 } \\
\text { 腦系統-硬體、軟體及應用系統、後置服務器、高性能跨越 } \\
\text { 網路之控制器) }\end{array}$ & $\begin{array}{l}\text { Other digital automatic data processing } \\
\text { machines :-- Comprising in the same housing } \\
\text { at least a central processing unit and an input } \\
\text { and output unit, whether or not combined (for } \\
\text { work processing stations and related to: RISC } \\
\text { CHIPS, multiprocessor systems, medical } \\
\text { optical cards, interface card, medical records } \\
\text { system, multimedia systems - hardware, } \\
\text { software and applications, back servers, high- } \\
\text { performance networks and controllers) }\end{array}$ & 84714100 & 847199 \\
\hline
\end{tabular}

\begin{tabular}{lll}
\hline 其他數位式自動資料處理機, 具系統形式者 & $\begin{array}{l}\text { Other digital automatic data processing } \\
\text { machines :-- Other, presented in the form of } \\
\text { systems }\end{array}$ & 84714900 \\
\hline 其他數位式自動資料處理機, 具系統形式者(高級工作站及 & $\begin{array}{l}\text { Other digital automatic data processing } \\
\text { machines :-- Other, presented in the form of } \\
\text { systems }\end{array}$ & 84714900 \\
相關RICS CHIPS、多處理機系統、醫療光卡、光卡閱讀機 & 847199 \\
\hline
\end{tabular}

個人電腦介面卡及光卡醫療記錄寫作系統、多媒體電腦系 
統-硬體、軟體及應用系統、後置服務器、高性能跨越網路

之控制器)

第 8471.41 及 8471.49 等目除外之數位式處

Digital processing units other than those of

84715000

8471

理單元, 在同一機殼內不論其是否含有一個或兩個下列形 sub-headings 8471.41 and 8471.49 , whether or not containing in the same housing one or two 式之單元 : 儲存單元、輸入單元、輸出單元(電子音樂合成 系統)

of the following types of unit : storage units, input units, output units

\begin{tabular}{|c|c|c|c|}
\hline 列表機 & Printers & 84716020 & 8471 \\
\hline 雷射印表機、光電成像印表機、高解析度頁印機 & $\begin{array}{l}\text { Laser printers, optical printers, high resolution } \\
\text { printers }\end{array}$ & 84716020 & 8471 \\
\hline $\begin{array}{l}\text { 其他輸入或輸出單元, 在同一機殼內不論其是否含有儲存 } \\
\text { 單元者 }\end{array}$ & $\begin{array}{l}\text { Input or output units, whether or not containing } \\
\text { storage units in the same housing }\end{array}$ & 84716090 & 847192 \\
\hline 高性能文件掃瞄器 & High performance scanner & 84716090 & 8471 \\
\hline 硬式磁碟機、微小型硬式磁碟機、微小型磁碟機 & $\begin{array}{l}\text { hard disk drives, micro hard drives, micro } \\
\text { drives }\end{array}$ & 84717010 & 847193 \\
\hline 其他儲存單元 & Other storage units & 84717090 & 847193 \\
\hline $\begin{array}{l}\text { 固態記憶系統、醫療光卡、光卡閱讀機個人電腦介面卡及 } \\
\text { 光卡醫療記錄寫作系統、IC記憶卡 }\end{array}$ & $\begin{array}{l}\text { Solid-state storage, medical optical cards, PC- } \\
\text { linked smart card readers, IC cards }\end{array}$ & 84717090 & 8471 \\
\hline 其他自動資料處理機單元 & $\begin{array}{l}\text { Other automatic data processors - magnetic or } \\
\text { optical readers }\end{array}$ & 84718000 & 847199 \\
\hline 磁性或光學閱讀機 & Magnetic or optical readers & 84719030 & 8471 \\
\hline $\begin{array}{l}\text { 條碼閱讀機、觸媒轉化器、醫療光卡、光卡閱讀機個人電 } \\
\text { 腦介面卡及光卡醫療記錄寫作系統 }\end{array}$ & $\begin{array}{l}\text { Barcode readers, catalytic converters, medical } \\
\text { optical cards, optical card reader PC interface } \\
\text { card and the optical card medical record } \\
\text { writing system }\end{array}$ & 84719030 & 8471 \\
\hline $\begin{array}{l}\text { 其他第 } 847 \text { 1 節所屬之自動資料處理機(其中電子音樂合 } \\
\text { 成系統及固態記憶系統為禁止類) }\end{array}$ & $\begin{array}{l}\text { Other automatic data processing machines } \\
\text { under the heading } 8471\end{array}$ & 84719090 & 847199 \\
\hline 電子音樂合成系統及固態記憶系統 & $\begin{array}{l}\text { Electronic music synthesis system and a solid- } \\
\text { state memory system }\end{array}$ & 84719090 & 847193 \\
\hline 第 8469 節機器之零件及附件 & $\begin{array}{l}\text { Parts and accessories of the machines of } \\
\text { heading } 84.69\end{array}$ & 84731000 & 8473 \\
\hline 其他第 8470 節所屬機器之零件及附件 & $\begin{array}{l}\text { Other parts and accessories of the machines of } \\
\text { heading } 84.70\end{array}$ & 84732900 & 8473 \\
\hline $\begin{array}{l}\text { 第 } 84771.10 、 8471.30 、 8471.41 、 \\
8471.49 、 8471.50 、 8471.60 、 8 \\
471.70 \text { 目機器之零件及附件 }\end{array}$ & $\begin{array}{l}\text { Other parts and accessories of the machines of } \\
\text { subheading8471.10, 8471.30, 8471.41, } \\
8471.49,8471.50,8471.60 \text { and } 8471.70\end{array}$ & 84733010 & 8473 \\
\hline $\begin{array}{l}\text { 影印機用墨粉、熱感應印字頭伺服寫入器、光纖網路用波 } \\
\text { 導蕅合器、高解析度雷射印表引擎、磁碟機讀寫頭 }\end{array}$ & $\begin{array}{l}\text { Photocopying machine toners, heat sensitive } \\
\text { printing \ head servo writer, fiber-optic } \\
\text { network with a waveguide coupler, high- } \\
\text { resolution laser printer engine, drives head }\end{array}$ & 84733010 & 8473 \\
\hline 第 847190.10 款下機械之零件及附件 & $\begin{array}{l}\text { Parts and accessories of the machines of } \\
\text { division } 8471.90 .10\end{array}$ & 84733021 & 8473 \\
\hline $\begin{array}{l}\text { 第 } 8471.80 \text { 、第 } 8471.90 \text { 目下機械之零件及 } \\
\text { 附件 }\end{array}$ & $\begin{array}{l}\text { Parts and accessories of the machines of } \\
\text { subheading } 8471.80 \text { and } 8471.90\end{array}$ & 84733029 & 8473 \\
\hline 打孔機、裝訂機及削鉛筆機之零件及附件 & $\begin{array}{l}\text { Parts and accessories of perforating } \\
\text { (punching), stapling, and pencil-sharpening } \\
\text { machines }\end{array}$ & 84734010 & 8473 \\
\hline $\begin{array}{l}\text { 同時適用於第 } 8471.80 、 8471.90 \text { 目下機械 } \\
\text { 之零件及附件 }\end{array}$ & $\begin{array}{l}\text { Parts and accessories equally suitable for use } \\
\text { with machinesofsubheading } 8471.80 \text { and } \\
8471.90\end{array}$ & 84735010 & 8473 \\
\hline
\end{tabular}




\begin{tabular}{|c|c|c|c|}
\hline 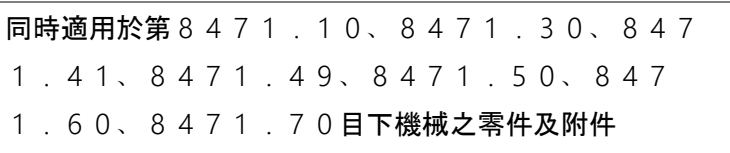 & $\begin{array}{l}\text { Parts and accessories equally suitable for use } \\
\text { with machinesofsubheading } 8471.10,8471.30 \text {, } \\
8471.41,8471.49,8471.50,8471.60 \text { and } \\
8471.70\end{array}$ & 84735020 & 8473 \\
\hline $\begin{array}{l}\text { 影印機用墨粉、熱感應印字頭伺服寫入器、光䌭網路用波 } \\
\text { 導藕合器、高解析度雷射印表引擎 }\end{array}$ & $\begin{array}{l}\text { photocopying machine toners, heat sensitive } \\
\text { printing \ head servo writer, fiber-optic } \\
\text { network with a waveguide coupler, high- } \\
\text { resolution laser printer engine }\end{array}$ & 84735020 & 8473 \\
\hline 精密微小馬達 & Precision small motors & 85011090 & 850110 \\
\hline 大尺寸/寬螢幕映像管(16：9 CRT) & Widescreen Desktop CRT & 85041100 & 8528 \\
\hline 交換式電源供應器(高功率密度、高頻電源供應器) & Switched mode power supplies & 85044011 & 850440 \\
\hline 不斷電式電源供應器(高功率密度、高頻電源供應器) & $\begin{array}{l}\text { UPS power supplies (high power density, high- } \\
\text { frequency power supply) }\end{array}$ & 85044012 & 850440 \\
\hline 其他電源供應器(高功率密度、高頻電源供應器) & $\begin{array}{l}\text { Other power supplies (high power density, } \\
\text { high frequency power supply) }\end{array}$ & 85044019 & 850440 \\
\hline $\begin{array}{l}\text { 其他靜電式變流器(微電腦控制交流感應馬達變頻器等相關 } \\
\text { 變頻器) }\end{array}$ & Other electrostatic converters & 85044090 & 850440 \\
\hline 附無線手機之有線電話機(整體服務數位網路用戶端設備) & Wireless and wired phones & 85171100 & 8517 \\
\hline 影像電話機 & Video phone & 85171910 & 8517 \\
\hline 其他電話機(整體服務數位網路用戶端設備) & Other phones (ISDN CPE) & 85171990 & 8517 \\
\hline G4傳真機、整體服務數網路用戶端設備 & fax machine, ISDN & 85172100 & 8517 \\
\hline 局用電話交換機 & Central office telephone exchange & 85173011 & 8517 \\
\hline 局用電話交換機(整體服務數網路用戶端設備) & $\begin{array}{l}\text { Central office telephone exchange (Integrated } \\
\text { services digital network CPE) }\end{array}$ & 85173011 & 8517 \\
\hline 其他電話交換機 & Other telephone exchange & 8517301990 & 8517 \\
\hline 其他電話交換機(整體服務數網路用戶端設備) & $\begin{array}{l}\text { Other telephone exchange (Integrated Services } \\
\text { Digital network CPE) }\end{array}$ & 85173019 & 8517 \\
\hline 數據機(整體服務數網路用戶端設備)+E5878 & $\begin{array}{l}\text { Modem (Integrated Services Digital network } \\
\text { CPE) }\end{array}$ & 85175010 & 8517 \\
\hline 其他載波電流線路系統用或數位線路系統用器具 & $\begin{array}{l}\text { Other carrier or digital line systems with } \\
\text { appliances }\end{array}$ & 85175090 & 8517 \\
\hline $\begin{array}{l}\text { 同步光纖網路ADM150系統、光纖迴路數位用戶載波機、 } \\
\text { 網路存取設備、光纖分散式數據界面、整體服務數網路用 } \\
\text { 戶端設備、多媒體、多重協定網路中樞、Ethernet to ATM } \\
\text { Smart Hub、高速數位用戶迴路設備、ISDN路由器、高速 } \\
\text { 乙太區域網路晶片組(速率100Mbps及以上)、區域性控制網 } \\
\text { 路系列產品、大容量光纖用戶迴路系統、數位式無線用戶 } \\
\text { 迴路傳輸設備、FAST ETHERNET高速乙太網路(速率 } \\
\text { 100Mbps及以上)、全方位網路技術之集線路 }\end{array}$ & $\begin{array}{l}\text { ADM150 synchronous optical network } \\
\text { systems, optical digital subscriber loop carrier } \\
\text { equipment, network } \ \text { take equipment, fiber } \\
\text { distributed data interface, Integrated Services } \\
\text { Digital network CPE, multimedia, multi- } \\
\text { protocol network hub, Ethernet to ATM Smart } \\
\text { Hub, High Speed digital subscriber loop } \\
\text { equipment, ISDN router, high-speed Ethernet } \\
\text { LAN chipset (speed of 100Mbps and above), } \\
\text { regional control network products, high- } \\
\text { capacity fiber-optic subscriber loop systems, } \\
\text { digital wireless subscriber loop transmission } \\
\text { equipment, FAST ETHERNET-speed B set } \\
\text { line too network (speed of 100Mbps and } \\
\text { above), the full range of network technology }\end{array}$ & 85175090 & 8517 \\
\hline
\end{tabular}

\begin{tabular}{llc}
\hline 數位錄放音帶機或數位卡帶錄放音機 & $\begin{array}{l}\text { Digital tape recorders or digital casette tape } \\
\text { players }\end{array}$ & 85203210 \\
\hline 其他數位錄放音器具 & other digital sound recording apparatus & 8520 \\
\hline
\end{tabular}




\begin{tabular}{|c|c|c|c|}
\hline 其他錄放音器具(數位錄放音機) & $\begin{array}{l}\text { Other sound recording apparatus (digital tape } \\
\text { players) }\end{array}$ & 85209000 & 8520 \\
\hline 其他磁帶式錄放影機(數位錄放影機) & Other tape-VCR (Digital Video Recorder) & 85211019 & 8521 \\
\hline 雷射光學系統碟式放影機 & Laser optical system disc video player & 85219010 & 8521 \\
\hline 雷射影音碟機 & Laser video disk players & 85219010 & 8521 \\
\hline 數位影音光碟機 & digital DVD player & 85219010 & 8521 \\
\hline 其他錄放影機 & other VCRs & 85219090 & 8521 \\
\hline 數位錄放影機 & digital VCR & 85219090 & 8521 \\
\hline 錄放音機之零件及附件(數位錄放音機機構體) & $\begin{array}{l}\text { Parts and accessories of tape players (digital } \\
\text { tape players) }\end{array}$ & 85229020 & 8522 \\
\hline 空白音碟 & blank audio CDs & 85232010 & 8523 \\
\hline 空白影碟 & blank DVDs & 85232020 & 8523 \\
\hline 自動資料處理系統之空白磁碟 & Blank disc automatic data processing systems & 85232030 & 8523 \\
\hline 硬碟機薄膜磁片 & cd and floppy drives & 85232030 & 8523 \\
\hline 多媒體系統 & multimedia systems & 85232090 & 8523 \\
\hline 多媒體電腦系統一硬體、軟體、及應用系統 & $\begin{array}{l}\text { Multimedia computer system - hardware, } \\
\text { software, applications }\end{array}$ & 85232090 & 8523 \\
\hline 多媒體電腦系統及其軟體 & Multimedia computer systems and software & 85232090 & 8523 \\
\hline 系統及工具性軟體 & Systems and Instrumental software & 85232090 & 8523 \\
\hline 多媒體資料庫管理系統 & Multimedia database management system & 85232090 & 8523 \\
\hline 系統軟體 & System software & 85232090 & 8523 \\
\hline 家庭資訊系統 & Family information systems & 85232090 & 8523 \\
\hline 高科技應用軟體系統 & High-tech application software systems & 85232090 & 8523 \\
\hline 電統輔助系統工程工具 & $\begin{array}{l}\text { Electrical systems auxiliary systems } \\
\text { engineering tools }\end{array}$ & 85232090 & 8523 \\
\hline 其他空白磁碟 & Other blank discs & 85232090 & 8523 \\
\hline 可重複讀寫光碟片 ( DVD-RAM, PD) & Rewritable CDs/DVDs & 85232090 & 8523 \\
\hline 磁片碟片 & Floppy disks & 85232090 & 8523 \\
\hline $\begin{array}{l}\text { 裝有磁條之卡片(多媒體電腦系統及其軟體、多媒體電腦系 } \\
\text { 統-硬體、軟體及應用系統、系統及工具性軟體、多媒體系 } \\
\text { 統) }\end{array}$ & $\begin{array}{l}\text { Equipped with a card magnetic strip } \\
\text { (multimedia computer systems and software, } \\
\text { multimedia computer systems - hardware, } \\
\text { software and applications, systems and tools of } \\
\text { software, multimedia systems) }\end{array}$ & 85233000 & 8523 \\
\hline $\begin{array}{l}\text { 其他錄音或錄製其他類似現象用之空白媒體(多媒體電腦系 } \\
\text { 統及其軟體、多媒體電腦系統-硬體、軟體及應用系統、系 } \\
\text { 統及工具性軟體、多媒體系統) }\end{array}$ & $\begin{array}{l}\text { Other recording media, blank or recorded } \\
\text { (multimedia computer systems and software, } \\
\text { multimedia computer systems - hardware, } \\
\text { software and applications, systems and tools of } \\
\text { software, multimedia systems) }\end{array}$ & 85239090 & 8523 \\
\hline 語言教學唱片 & language teaching records & 85241010 & 8524 \\
\hline 音樂唱片 & recorded music & 85241020 & 8524 \\
\hline 其他唱片 & Other records & 85241090 & 8524 \\
\hline 已錄製供重放聲音或影像以外現象之碟片 & $\begin{array}{l}\text { Recorded discs for reproducing phenomena } \\
\text { other than sound or image }\end{array}$ & 85243100 & 8524 \\
\hline 教育性、新聞性音碟 & Educational, news, and audio CDs & 85243211 & 8524 \\
\hline 其他已錄製音碟 & Other recorded audio CDs & 85243219 & 8524 \\
\hline 教育性、新聞性影碟 & Educational and news DVDs & 85243910 & 8524 \\
\hline
\end{tabular}




\begin{tabular}{|c|c|c|c|}
\hline 其他已錄製供雷射閱讀系統用碟片 & Discs for laser reading systems :-- Other & 85243990 & 8524 \\
\hline $\begin{array}{l}\text { 已錄製供重放聲音或影像以外現象之磁帶，寬度超過 } 6 \text {. } \\
5 \text { 毫米者 }\end{array}$ & $\begin{array}{l}\text { Recorded tapes for reproducing phenomena } \\
\text { other than sound or image - of a width } \\
\text { exceeding } 6.5 \mathrm{~mm}\end{array}$ & 85244030 & 8524 \\
\hline 教育性、新聞性錄音帶, 寬度未超過 4 毫米者 & $\begin{array}{l}\text { Educational and news audio tapes, width no } \\
\text { more than } 4 \mathrm{~mm}\end{array}$ & 85245111 & 8524 \\
\hline 教育性、新聞性錄影帶, 寬度未超過 4 毫米者 & $\begin{array}{l}\text { Educational and news videos, width no more } \\
\text { than } 4 \mathrm{~mm}\end{array}$ & 85245121 & 8524 \\
\hline $\begin{array}{l}\text { 教育性、新聞性錄音帶，寬度超過 } 4 \text { 毫米，但未超過 } 6 \\
5 \text { 毫米者 }\end{array}$ & $\begin{array}{l}\text { Educational and news audio tapes, width } \\
\text { between } 4 \text { and } 6.5 \mathrm{~mm}\end{array}$ & 85245211 & 8524 \\
\hline $\begin{array}{l}\text { 教育性、新聞性錄影帶，寬度超過 } 4 \text { 毫米，但未超過 } 6 \\
5 \text { 毫米者 }\end{array}$ & $\begin{array}{l}\text { Educational and news videos, width between } 4 \\
\text { and } 6.5 \mathrm{~mm}\end{array}$ & 85245221 & 8524 \\
\hline 教育性、新聞性錄音帶, 寬度超過 6.5 毫米者 & $\begin{array}{l}\text { Educational and news audio tapes, width over } \\
6.5 \mathrm{~mm}\end{array}$ & 85245311 & 8524 \\
\hline 教育性、新聞性錄影帶, 寬度超過 $6 \cdot 5$ 毫米者 & $\begin{array}{l}\text { Educational and news videos, width over } \\
6.5 \mathrm{~mm}\end{array}$ & 85245321 & 8524 \\
\hline 其他已錄製錄影帶, 寬度超過 6.5 毫米者 & Other recorded videos, width over $6.5 \mathrm{~mm}$ & 85245329 & 8524 \\
\hline 其他已錄製磁帶，寬度超過 6 . 5 毫米者 & Other recorded tapes, width over $6.5 \mathrm{~mm}$ & 85245390 & 8524 \\
\hline 裝有已錄製磁條之卡片 & Recorded cards with a magnetic strip & 85246000 & 8524 \\
\hline 已錄製供重放聲音或影像以外現象之媒體 & $\begin{array}{l}\text { Recorded media for reproducing phenomena } \\
\text { other than sound or image }\end{array}$ & 85249100 & 8524 \\
\hline $\begin{array}{l}\text { 醫療光卡、光卡閱讀機個人電腦介面及光卡醫療記錄寫作 } \\
\text { 系統 }\end{array}$ & $\begin{array}{l}\text { Medical optical cards, optical card reader PC } \\
\text { interface, and optical card medical record }\end{array}$ & 85249300 & 8524 \\
\hline 其他已錄音或已錄製其他類似現象之媒體 & $\begin{array}{l}\text { Other music recordings or other similar media } \\
\text { recordings }\end{array}$ & 85249900 & 8524 \\
\hline 無線電廣播傳輸器具 & Radio transmission apparatus & 85251020 & 8525 \\
\hline 電視傳輸器具 & TV transmission apparatus & 85251030 & 8525 \\
\hline 其他無線電傳輸機器 & Other radio transmission machines & 85251090 & 8525 \\
\hline 無線電話機 & Radio phone & 85252010 & 8525 \\
\hline 其他具有接收器具之無線電傳輸器具 & Other radio transmission receivers & 85252090 & 8525 \\
\hline 靜相攝影機 & Static camcorder & 85254010 & 8525 \\
\hline 電子靜相照像機 & Static photography & 85254010 & 8525 \\
\hline $\begin{array}{l}\text { 其他無線電話或無線電報接收機(全球定位系統接收器、全 } \\
\text { 球定位系統接器及引擎、國際海事衛星通信M/B型移動系 } \\
\text { 統及網際網路口袋型電腦通訊器) }\end{array}$ & $\begin{array}{l}\text { Other wireless telephone or wireless } \\
\text { telegraphy receivers }\end{array}$ & 85279000 & 852790 \\
\hline $\begin{array}{l}\text { 彩色電視接收器具, 不論是否裝有無線電廣播接收機或 } \\
\text { 音、影錄或放器具者[高級數位電視機、高畫質電視機(水 } \\
\text { 平解析度在 } 1000 \text { 條以上)] }\end{array}$ & $\begin{array}{l}\text { Color TV reception apparatus, whether or not } \\
\text { incorporating radio broadcast receivers or } \\
\text { sound, video recording or reproducing } \\
\text { apparatus by TV (resolution of more than } \\
1000 \text { ) }\end{array}$ & 85281200 & 852810 \\
\hline 彩色閉路電視系統 & Color CCTV System A & 85282110 & 852820 \\
\hline 17吋以上彩色影像監視器 & 17-inch or more color video monitors & 85282190 & 852820 \\
\hline 彩色影像投射機 & Color projector & 85283010 & 852830 \\
\hline 彩色影像投射機(投影式電視機、液晶投影電視機) & Color projector (tv projector, LCD projector) & 85283010 & 852830 \\
\hline 黑白或其他單色影像投射機(數位式) & $\begin{array}{l}\text { Black and white monochrome video projectors } \\
\text { (digital type) }\end{array}$ & 85283020 & 852830 \\
\hline 電腦數值控制器，PC級腦數值控制器 & Computer numerical control (CNC) & 85371010 & 853710 \\
\hline 電子靜相照像機 & Static camera & 90065900 & 9006 \\
\hline 數位攝錄放影機 & Digital camcorders & 90079100 & 9007 \\
\hline 第 9013 節所屬物品之零件及附件 & HS Code 9013, parts and accessories & 90139000 & 901390 \\
\hline
\end{tabular}

